\title{
Effects of Recycled Water on Landscape Plants
}

\author{
A Thesis \\ Presented to the Faculty of \\ California State Polytechnic University San Luis Obispo \\ In Partial Fulfillment \\ of the Requirements for the Degree of \\ Master of Science in Agriculture
}

With a Specialization in Environmental and Horticultural Science

By

Casey Miranda

June 2010 
(C) 2010

Casey Ray Miranda

ALL RIGHTS RESERVED 
COMMITTEE MEMBERSHIP

TITLE:

Effects of Recycled Water on Landscape Plants

AUTHOR:

Casey Miranda

DATE SUBMITTED:

June 16, 2010

COMMITTEE CHAIR:

David W. Hannings, M.S.

COMMITTEE MEMBER:

Terry L. Vassey, Ph.D.

COMMITTEE MEMBER: Chip Appel, Ph.D. 


\section{ABSTRACT \\ EFFECTS OF RECYCLED WATER ON LANDSCAPE PLANTS \\ Casey Ray Miranda}

Recycled water is water that has been previously used, has suffered a loss of quality, and has been properly treated for redistribution (Wu et al. 2001). The use of recycled water as an alternative to fresh water in the landscape can have positive and negative effects. Experimentation on 40 different plant species during a 32 week period ( 2 phases of 16 weeks), was conducted to analyze the effects of recycled water irrigation on the appearance of landscape plants. Each species of plant was planted into 10 individual number 2 pots and irrigated with recycled water daily. Media and water were tested for nutrients and other constituents. In phase I there were four different species of grasses and grass-like plants, five different perennials, five species of shrubs, and four annuals tested; while phase II tested four species of herbaceous perennials, eight different species of shrubs, six species of groundcovers, and four species of annuals. All tests were conducted at the Paso Robles Waste Water Treatment Plant. Of the grasses and grass like species $\underline{\text { Yucca spp. and Buchloe spp. performed best. Osteospermum }}$ $\underline{\text { fruticosum, }}, \underline{\text { Lavandula angustifolia, }}, \underline{\text { Rosmarinus }} \underline{\text { officinalis, }}, \underline{\text { Phormium tenax }}$, and Pennisetum $\underline{\text { setaceum }}$ had the best appearance of the herbaceous perennials tested. For the shrubs, Coprosma

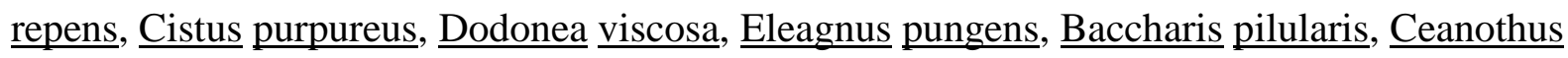
$\underline{\text { thysiflorus, }} \underline{\text { Thuja }} \underline{\underline{\text { orientalis}}}$, and Nerium oleander had the best appearance when irrigated with recycled water. The best annuals were $\underline{\text { Senecio }} \underline{\text { cineraria, }}$ Antirrhinum majus, Primula spp., Viola

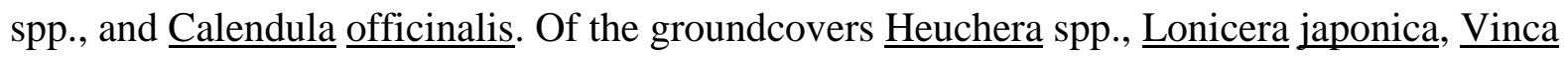

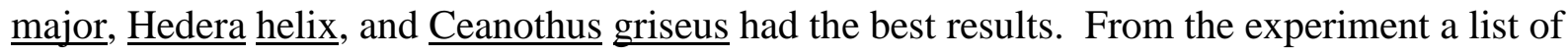


tolerant and non-tolerant plants was compiled (Appendices 1 and 2). While many plants were capable of developing and growing normally, other plants were sensitive to recycled water irrigation. In order to prevent salt damage to plants and expand the use of recycled water, salt tolerance of landscape plant material must be identified (Niu et.al, 2006).

Keywords: Recycled Water, Salinity, Salt Tolerance, Irrigation, Plant Tolerance 


\section{TABLE OF CONTENTS}

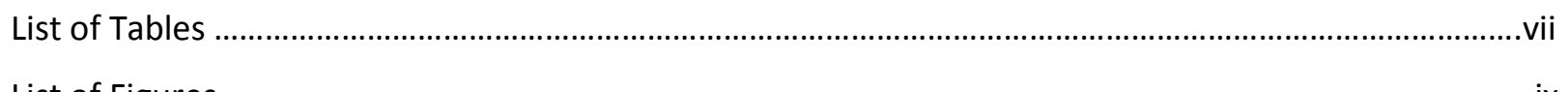

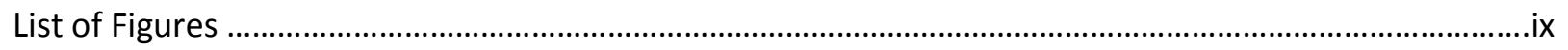

Literature Review

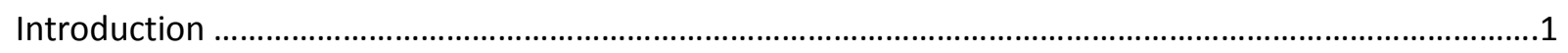

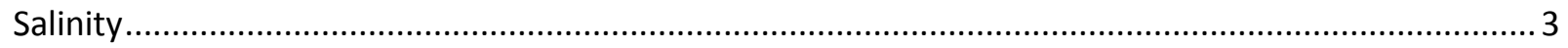

Electrical Conductivity (EC) as a Description of Salinity ................................................................... 4

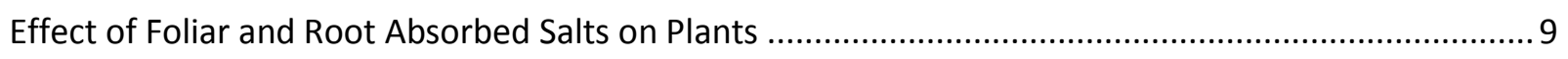

Environmental Factors Influencing Salt Accumulation .................................................................... 10

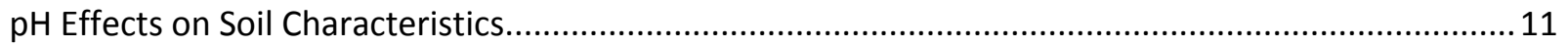

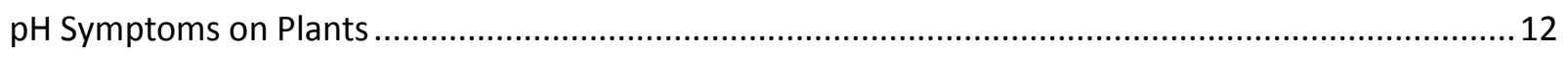

Sodium Adsorption Ratio (SAR)/ Exchangeable Sodium Percentage (ESP) ....................................... 15

Types of Salt-Affected Soils and Their Effect on Plants .............................................................. 16

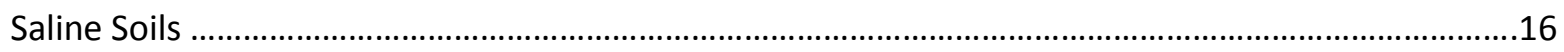

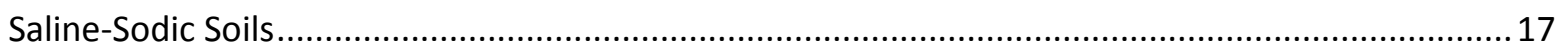

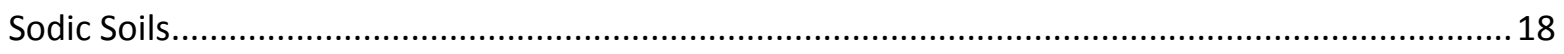

Effects of Osmotic Potential and Ion Toxicity on Plants from Salt-Affected Soils ................................ 19

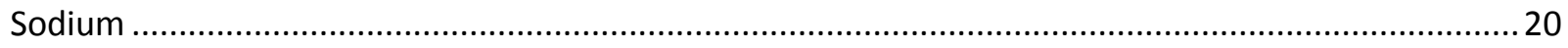

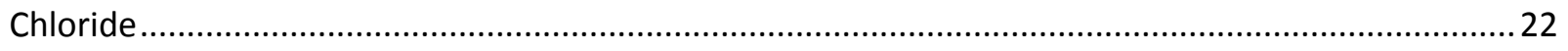

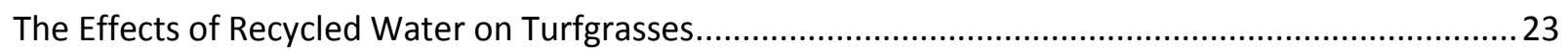

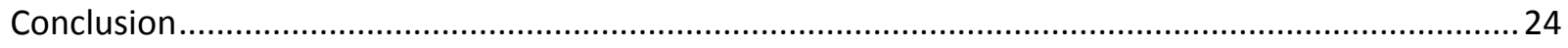

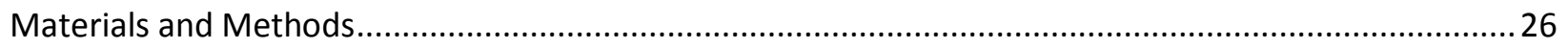

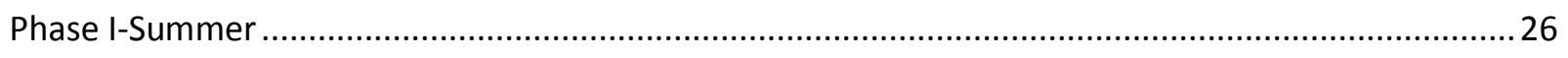

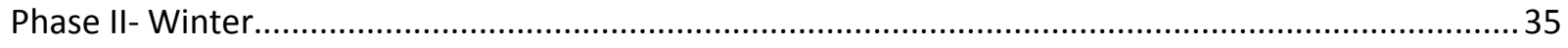

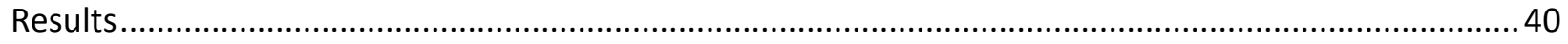

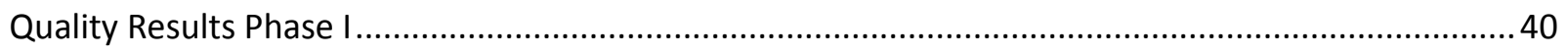

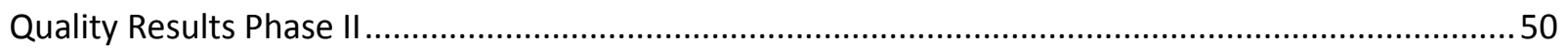




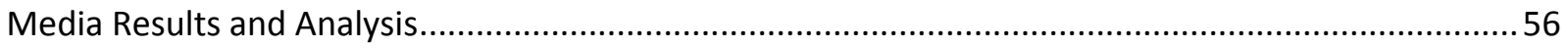

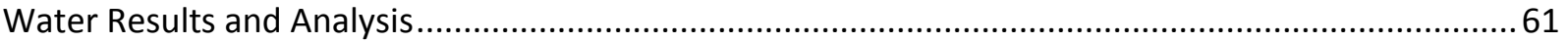

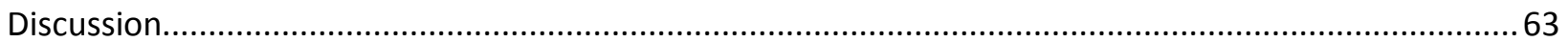

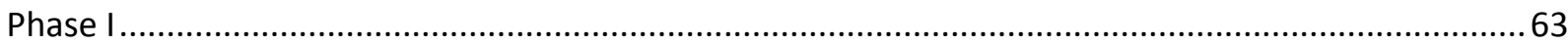

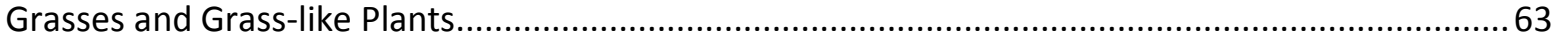

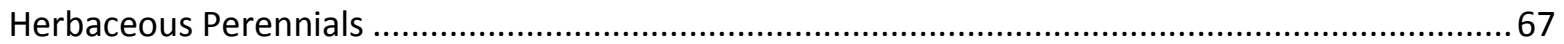

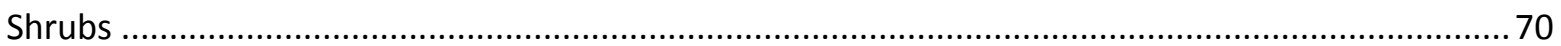

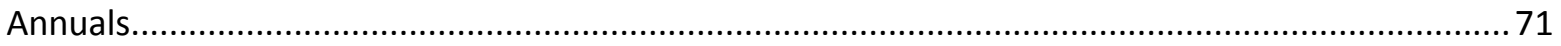

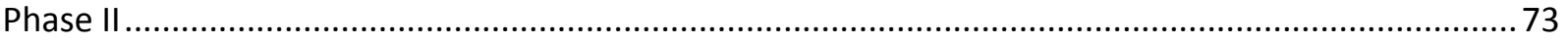

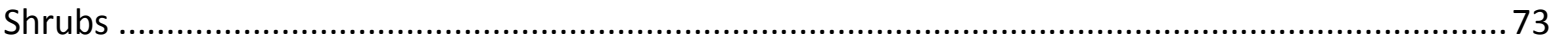

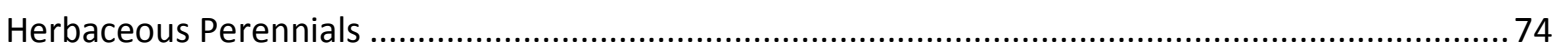

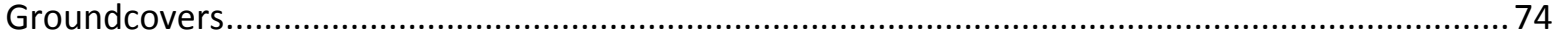

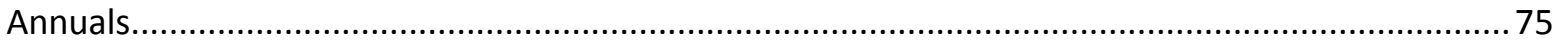

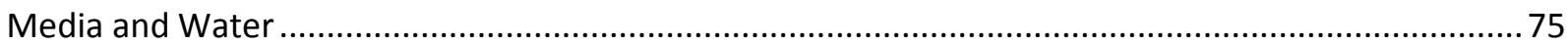

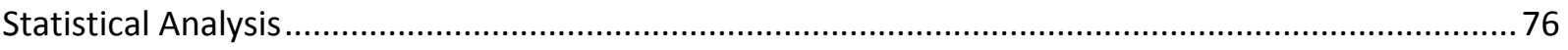

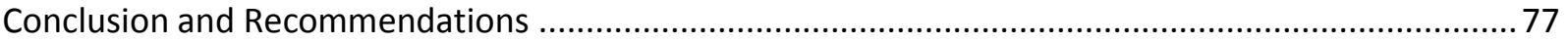

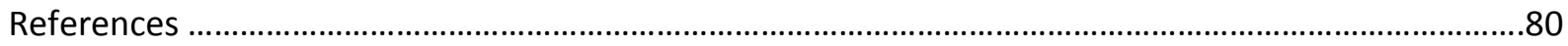




\section{TABLES AND FIGURES}

Table 1. Guidelines for Interpreting Results of Salts in Soil \& Water ....................................... 4

Table 2: Effects of Electrical Conductivity (EC) of Irrigation Water on Aesthetics and Growth

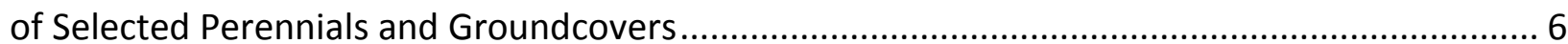

Table 3: Chemical Properties of Field and Container Soils After 6 weeks of Irrigation with Sprinkler and Drip Systems and Three Salt Concentrations. ................................................. 8

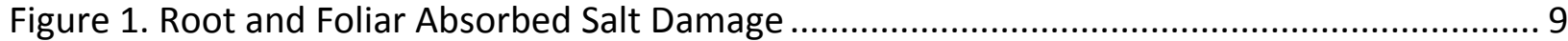

Figure 2: Availability of Nutrients at Different pH Levels ................................................. 12

Figure 3: Nutrient Deficiency Symptoms ................................................................................... 13

Table 4: Contrast and Effect of Potable and Recycled Water on Selected Plants ...................... 14

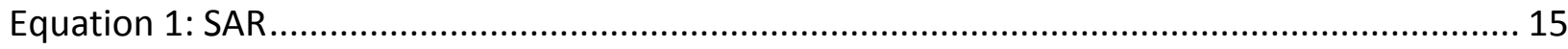

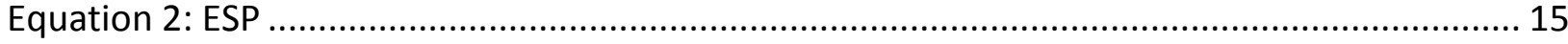

Figure 4: Relationship of salt affected soils to $\mathrm{pH}, \mathrm{EC}, \mathrm{SAR}, \mathrm{ESP}$ and Class of Soils in relation

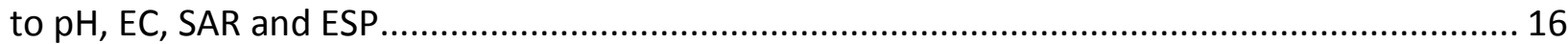

Figure 5: Relationship between ESP and Hydraulic Conductivity.......................................... 21

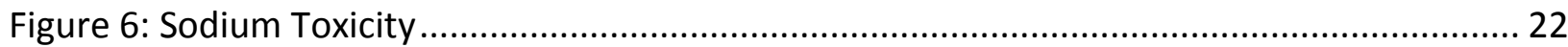

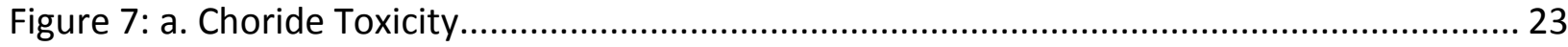

Table \#5: The Relative Tolerances of Turf Grass Species to Soil Salinity (ECe) ......................... 24

Figure 8: Average and Record Temperatures for Paso Robles, California............................... 27

Figure 9: Average Precipitation for Paso Robles, California .................................................. 27

Figure 10: Plant Species and Their Relative Salt Tolerance ..................................................... 29

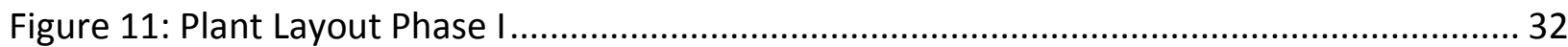

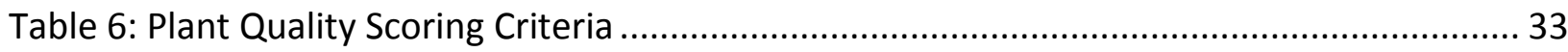

Table 7: Plant Species Media Combined for Analysis .............................................................. 34

Table 8: Plant Species and Their Relative Salt Tolerance ..................................................... 36

Figure 12: Phase I and Phase II Plant Layout ...................................................................... 39

Figure 13: Quality Results for Grasses Planted in 80\% Sand, 20 \% Peat Moss Media ................ 40 Figure 14: Quality Results for Grasses Planted in 40\% Sand, 40\% Peat Moss, and 20\% Perlite

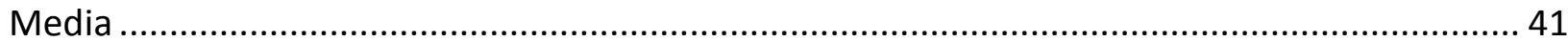

Figure 15: Quality Results for Herbaceous Perennials Planted in $80 \%$ Sand and 20\% Peat Moss Media.

Figure 16: Quality Results for Herbaceous Perennials Planted in 40\% Sand, 40\% Peat Moss, \& 20\% Perlite Media 
Figure 17: Quality Results for Shrubs Planted in 80\% Sand and 20\% Peat Moss Media..... 45

Figure 18: Quality Results for Shrubs Planted in 40\% Sand, 40\% Peat Moss, and 20\% Perlite Media 46

Figure 19: Quality Results for Annuals Planted in 80\% Sand and 20\% Peat Moss Media 48

Figure 20: Quality Results for Annuals Planted in 40\% Sand, 40\% Peat Moss, and 20\% Perlite Media 49

Figure 21: Quality Results of Shrubs Planted in 40\% Sand, 40\% Peat Moss, and 20\% Perlite Media 50

Figure 22: Quality results of Herbaceous Perennials Planted in $40 \%$ Sand, $40 \%$ Peat Moss, 20\% Perlite Media

Figure 23: Quality Results of Groundcovers Planted in 40\% Sand, 40\% Peat Moss, and 20\% Perlite Media. 53

Figure 24: Quality Results of Annuals Planted in 40\% Sand, 40\% Peat Moss, and 20\% Perlite Media 55

Figure 25: pH Results for 40\% Sand, 40\% Peat Moss, and 20\% Perlite Media (Phase I, Week 4).

Fig. 26: Electrical Conductivity $\left(\mathrm{EC}_{\mathrm{e}}\right)$ Results for $40 \%$ Sand, $40 \%$ Peat Moss, and $20 \%$ Perlite Media (Phase I, Week 4)

Fig. 27: Sodium Adsorption Ratio (SAR) Results for $40 \%$ Sand, $40 \%$ Peat moss, and $20 \%$ Perlite (Phase I, Week 4) 58

Fig. 28: pH Result for 40\% Sand, 40\% Peat Moss, and 20\% Perlite Media (Phase I, Week 12).... 59 Fig. 29: Electrical Conductivity ( $E C_{e}$ ) Results for $40 \%$ Sand, $40 \%$ Peat Moss, and $20 \%$ Perlite Media (Phase I, Week 12).

Fig. 30: Sodium Adsorption Ratio (SAR) Results for 40\% Sand, 40\% Peat Moss, and 20\% Perlite (Phase I, Week 12) 61

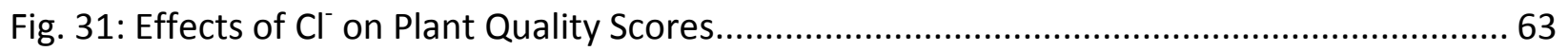

Fig. 32: Effects of Nitrogen in the media on Plant Quality Score ...........................................6 66

Fig. 33: Effects of Phosphorous in the media on Plant Quality Scores ...................................... 66

Fig. 34: Effects of Potassium in Media on Plant Quality Scores ............................................ 67

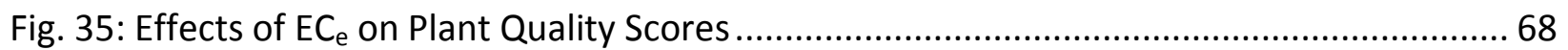

Figure 36: Estimate Marginal Mean by Media .................................................................... 79 


\section{$\underline{\text { Literature Review }}$}

\section{Introduction}

Proper irrigation of annual and perennial plants is important for their sustainable health, growth, and aesthetics in the landscape. As the quantity of freshwater availability worldwide declines, conservation efforts and the efficient use of this valuable resource become a pressing issue (Gross et al., 2007). Other than drinking and bathing, irrigation is one of the most important uses of water and accounts for $60 \%$ of the world's freshwater withdrawals (USGS). In arid regions of the world, the efficient distribution of freshwater or potable water for drinking and crop irrigation is of great importance. Since many of the western U.S. states are growing in population, the need for water in supporting that growth is critical, and will govern future growth of those areas (Kjelgren et al., 2000). When evaluating the vitality of freshwater resources and prioritizing its allocation, landscape plants usually move to the bottom of the list, behind drinking water and crop irrigation. Also, as the impact of humans on the environment increases, soil scientists have began to focus their work on the effects of agricultural and other land management practices on the environment (Bonds, 1998). The use of recycled water $(\mathrm{RW})$, also known as wastewater or reclaimed water, for irrigating landscape plants is one of these agricultural management practices used to help sustain healthy environmental conditions and natural resources.

Recycled water can be described as being previously used, has suffered a loss of quality, and has been properly treated for redistribution (Wu et al., 2001). The sources from which it is reclaimed include agricultural drainage water, runoff losses from agricultural irrigation systems and fields, sewage water from cities, leakage from water 
supply systems, high percolation losses from irrigated fields, wastewater from water treatment plants, and other water sources reaching these systems (Hussain and Al Saati, 1999). The value of recycled irrigation water is that it enables users to effectively maintain their landscapes without depleting freshwater resources. In arid areas of the United States, low rainfall can deprive landscapes not only of natural rain irrigation, but also limit freshwater resources available to the landscapes. A majority of plants require periods of consistent irrigation for proper root development in new landscapes (Kjelgren et al., 2000). Reclaimed water gives users alternative sources for watering landscape plants that undoubtedly need the water for their establishment.

The use of RW to irrigate multiple plant species is not widely practiced, due to the possible hazards such as salt injury (Niu and Rodriguez, 2006a). Since plant species have different thresholds for tolerating exposure to salts (i.e., through leaves or uptake in the roots), plant selection by users of recycled water can be difficult. For landscape plants, visual aesthetics are more important than maximum growth, and; therefore evaluation of salinity tolerance should focus on visual appearance along with plant growth response (Niu and Rodriguez, 2006a). In regards to RW and salt injury, salt tolerance of plants is an important factor that can affect visual aesthetics and overall plant health and development. Since there are numerous factors that play an integral part in sustainable plant health, it is important to understand which ones are most crucial.

Salinity (total dissolved salts) is the single most important parameter in determining the suitability of water used for irrigation (USEPA, 2004). In order to prevent salt damage to plants and expand the use of RW, salt tolerant landscape plant material must be identified (Niu and Rodriguez, 2006a.). Salinity in RW can affect 
proper plant growth. Using soil and water measures of $\mathrm{pH}, \mathrm{EC}, \mathrm{SAR}$ and/or ESP, help to determine and manage salinity. This thesis will focus on the effects of using recycled irrigation water on the aesthetics and growth of landscape plants and the soils in which they are grown.

\section{Salinity}

When evaluating recycled water and its use to irrigate landscape plants, it is important to understand the constituents in the water that are distributed throughout the soil. Soils contain a mixture of water-soluble salts that are necessary for plant growth and function; however, they can be injurious to plants at high concentrations (Costello et al., 2003). This excess accumulation of salts is described as salinization and these salts are mainly chlorides and sulfates of calcium, magnesium, potassium, and sodium (Brady and Weil, 2008) and are the salts that most commonly cause damage to plants within the soil (Costello et al., 2003). Sodium and other salts can accumulate through weathering of rocks and other material in the soil, or by addition to the soil from fertilizers, rain, and irrigation with recycled water (Costello et al., 2003). Salts in recycled irrigation water are absorbed by plants either through the roots or foliage of the plant.

Mechanisms have been developed to help manage and measure the amount of salts in the soil, as well as in irrigation water. These mechanisms of measuring salinity include: $\mathrm{pH}$, total dissolved solids (TDS), electrical conductivity (EC), and exchangeable sodium percentage (ESP) and/or sodium adsorption ratio (SAR), which are two expressions commonly used to characterize the sodium status of soils (Brady and Weil, 2008). The roles that EC, ESP and/or SAR, and pH play individually, as well as 
collectively, are critical factors for plant development in different soils, and help to measure the levels of salinity and sodium in soil and irrigation water. Table 1 shows the acceptable levels of salinity and salt exposure in soil and water for most plants.

Table 1. Guidelines for Interpreting Results of Salts in Soil \& Water (from Pettygrove and Asano 1985)

\begin{tabular}{|l|c|c|c|}
\hline & Generally Safe & $\begin{array}{c}\text { Slight to } \\
\text { Moderate }\end{array}$ & Severe \\
\hline Soil analyses & & & \\
\hline salinity $\left(\mathrm{EC}_{\mathrm{e}}\right.$ ), dS/m & $0.5-2.0$ & $2.0-4.0$ & 4.0 \\
\hline sodium adsorption ratio (SAR) & $<6$ & $7-9$ & $>9$ \\
\hline sodium, mg/l & $0.1-0.5$ & $1-5$ & $>5$ \\
\hline boron, mg/l & $<100$ & $100-200$ & $>250$ \\
\hline chloride, mg/l & $0-25$ & $>25$ & \\
\hline ammonium, mg/l & $<450$ & $450-2000$ & $>2000$ \\
\hline Water analyses & $<0.7$ & $0.7-3.0$ & $>3.0$ \\
\hline total dissolved solids (TDS), mg/l & $<0.5$ & $0.5-1.0$ & $>1.0$ \\
\hline salinity $(\mathrm{EC}$ w), dS/m & $<140$ & $140-300$ & $>350$ \\
\hline boron,mg/l & $<100$ & $>100$ & $>9$ \\
\hline $\begin{array}{l}\text { Chloride } \\
\text { surface irrigation, mg/l } \\
\text { sprinkler irrigation, mg/l }\end{array}$ & $<3$ & $3-9$ & \\
\hline $\begin{array}{l}\text { Sodium } \\
\text { surface irrigation }(\mathrm{SAR}) \\
\text { sprinkler irrigation, mg/l }\end{array}$ & $<70$ & $>70$ & \\
\hline
\end{tabular}

\section{Electrical Conductivity (EC) as a Description of Salinity}

Measuring the salinity of soil is an important determinant when selecting plants for landscape settings. Soil salinity can be found by taking the electrical conductivity $\left(\mathrm{EC}_{\mathrm{e}}\right)$ of solution which is measured in a water-saturated soil paste and expressed in units of decisiemen (dS/m) (Kotuby-Amacher et al., 2000). Water salinity can be expressed as total dissolved solids (TDS) and $\left(\mathrm{EC}_{\mathrm{w}}\right)$. Table 1 also gives an interpretation of ranges for specific constituents and their acceptable and non-acceptable levels in the soil and water. 
When $\mathrm{EC}_{\mathrm{e}}$ levels exceed $4 \mathrm{dS} / \mathrm{m}$, salt sensitive plants may be damaged. Woody plants considered to be salt tolerant may not show damage until levels reach $10 \mathrm{dS} / \mathrm{m}$. For most plants, TDS should be below 1,000 ppm and $\mathrm{EC}_{\mathrm{w}}$ should be below $2 \mathrm{dS} / \mathrm{m}$ (Costello et al., 2003). Since salt tolerance is variable among different species of plants, a number of experiments have been conducted in order to identify effects that recycled water has on aesthetics and growth, and to identify the tolerances of many species of plants.

In a mock recycled water experiment by Niu and Rodriguez (2006a), saline irrigation water with EC values of $0.8,3.2,6.4$, and $12.0 \mathrm{dSm}^{-1}$ was added to the root substrate of eight herbaceous perennials for an 11 week period and analyzed for the effects on aesthetics and growth of the plants. Two species of plants with different salt tolerances (salt sensitive, Ceratostigma plumbaginoides and moderate to tolerant Delosperma cooperi) of the eight plants tested, demonstrated differences in root/shoot dry weight for each saline treatment (Table 2). Ceratostigma plumbaginoides grew less as EC increased while $\underline{\mathrm{D}}$. cooperi, had an increase in shoot dry weight throughout most of the treatments, with exception of the final most severe treatment where it decreased only slightly. Visual aesthetics was measured using a ranking of 1-5; with 1 being dead and 5 being perfect. Ceratostigma plumbaginoides exhibited a decreased in aesthetics from 5.0 (rated as excellent with vigorous growth and no damage) at $0.8 \mathrm{dS} / \mathrm{m}$ they found that aesthetics decrease to 1.7 (meaning severe stunted growth with $50 \%$ leaf injury) at 12.0 $\mathrm{dS} / \mathrm{m}$ Delosperma cooperi actually only slightly increased in aesthetics. Another experiment testing EC levels $(0.8,2.0$, and $4.0 \mathrm{dS} / \mathrm{m})$ on five different herbaceous perennials irrigated by saline solution, revealed no major reduction in plant growth or aesthetic change took place with any treatment (Niu and Rodriguez 2006 b). These two 
experiments show that salt tolerance varies from plant species to plant species and at different salinity levels.

Table 2: Effects of Electrical Conductivity (EC) of Irrigation Water on Aesthetics and Growth of Selected Perennials and Groundcovers (Exerpeted from (Niu and Rodriguez 2006 a)

\begin{tabular}{|c|c|c|c|c|c|c|c|c|c|}
\hline Species & 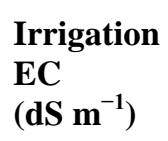 & $\begin{array}{l}\text { Root } \\
\text { DW } \\
\text { (g) }\end{array}$ & $\begin{array}{l}\text { Shoot } \\
\text { DW } \\
\text { (g) }\end{array}$ & $\begin{array}{l}\text { Leaching } \\
\text { EC } \\
\left(\mathrm{dS} \mathrm{m}^{-1}\right)\end{array}$ & $\begin{array}{l}\text { Aesthetic } \\
\text { Score per } \\
\text { treatment }\end{array}$ & $\begin{array}{l}\mathrm{Ca} \\
(\mathrm{mg} / \mathrm{g})\end{array}$ & $\begin{array}{l}\mathrm{Mg} \\
(\mathrm{mg} / \mathrm{g})\end{array}$ & $\begin{array}{l}\mathrm{Na} \\
(\mathrm{mg} / \mathrm{g})\end{array}$ & $\begin{array}{l}\mathrm{Cl} \\
(\mathrm{mg} / \mathrm{g})\end{array}$ \\
\hline \multirow[t]{4}{*}{ C. plumbaginoides } & 0.8 & 7.72 & 51.02 & 2.65 & 5.0 & $\begin{array}{l}\text { S-7.70 } \\
\text { R-3.35 }\end{array}$ & $\begin{array}{l}\text { S-4.03 } \\
\text { R-1.78 }\end{array}$ & $\begin{array}{l}\text { S-2.58 } \\
\text { R-2.05 }\end{array}$ & $\begin{array}{l}\text { S-8.57 } \\
\text { R-5.74 }\end{array}$ \\
\hline & 3.2 & 6.68 & 27.12 & 8.60 & 2.9 & $\begin{array}{l}8.70 \\
3.28\end{array}$ & $\begin{array}{l}5.35 \\
1.98\end{array}$ & $\begin{array}{l}8.53 \\
3.95\end{array}$ & $\begin{array}{l}30.31 \\
11.74\end{array}$ \\
\hline & 6.4 & 4.21 & $\begin{array}{c}19.1 \\
1\end{array}$ & 12.88 & 2.9 & $\begin{array}{l}10.35 \\
2.90\end{array}$ & $\begin{array}{l}6.23 \\
1.78\end{array}$ & $\begin{array}{c}20.88 \\
4.95\end{array}$ & $\begin{array}{l}58.89 \\
13.14\end{array}$ \\
\hline & 12.0 & - & - & - & 1.3 & $\begin{array}{l}- \\
-\end{array}$ & $\begin{array}{l}- \\
-\end{array}$ & $\begin{array}{l}- \\
-\end{array}$ & $\begin{array}{l}- \\
-\end{array}$ \\
\hline \multirow[t]{4}{*}{ D. cooperi } & 0.8 & 2.95 & 28.38 & 1.83 & 3.8 & $\begin{array}{l}\text { S-12.73 } \\
\text { R-16.93 }\end{array}$ & $\begin{array}{l}\text { S-14.58 } \\
\text { R- } 3.93\end{array}$ & $\begin{array}{c}\text { S-4.23 } \\
\text { R-16.78 }\end{array}$ & $\begin{array}{c}\text { S-46.96 } \\
\text { R-5.08 }\end{array}$ \\
\hline & 3.2 & 3.71 & 30.94 & 6.85 & 4.3 & $\begin{array}{l}12.63 \\
16.27\end{array}$ & $\begin{array}{c}15.60 \\
3.98\end{array}$ & $\begin{array}{c}4.75 \\
17.97\end{array}$ & $\begin{array}{l}80.99 \\
10.54\end{array}$ \\
\hline & 6.4 & 3.41 & 33.71 & 10.95 & 4.0 & $\begin{array}{l}12.55 \\
15.10\end{array}$ & $\begin{array}{c}13.10 \\
3.23\end{array}$ & $\begin{array}{c}8.50 \\
17.60\end{array}$ & $\begin{array}{l}97.17 \\
15.51\end{array}$ \\
\hline & 12.0 & 2.95 & 21.54 & 18.43 & 4.0 & $\begin{array}{l}10.83 \\
16.85\end{array}$ & $\begin{array}{c}10.40 \\
3.78\end{array}$ & $\begin{array}{l}12.90 \\
22.45\end{array}$ & $\begin{array}{l}99.14 \\
23.92\end{array}$ \\
\hline \multicolumn{10}{|c|}{$\begin{array}{l}\text { (- Indicates plants dead and data unable to be collected) } \\
\text { (S-Shoot R- Root) (Aesthetic Score } 0 \text {, dead; } 1 \text {, severe stunted growth with over } 50 \% \text { leaf injury; } 2 \text {, somewhat stunted } \\
\text { growth with moderate }(25-50 \%) \text { leaf injury; } 3 \text {, average quality with slight }(<25 \%) \text { leaf injury; } 4 \text {, good quality with } \\
\text { acceptable growth reduction and little leaf injury; } 5 \text {, excellent with vigorous growth with no leaf injury. Irrigation water } \\
\text { of } 0.8 \mathrm{dS} \mathrm{m}{ }^{-1} \text { was tap water.) }\end{array}$} \\
\hline
\end{tabular}


Ions such as $\mathrm{Na}^{+}, \mathrm{K}^{+}$, and $\mathrm{Cl}^{-}$may be directly harmful and must be carefully regulated by plants to avoid toxicities (Quist and Williams, 1999). Delosperma cooperi in Niu and Rodriguez' (2006 a) experiment exhibited the ability to physiologically regulate these harmful salts at different EC levels, while even at lower EC levels, $\underline{\mathrm{C}}$. plumbaginoides could not. An important finding worth noting was that $\underline{\mathrm{D}} \underline{\text { cooperi, }}$ although salt tolerant, contained higher ionic concentrations in shoots and roots in

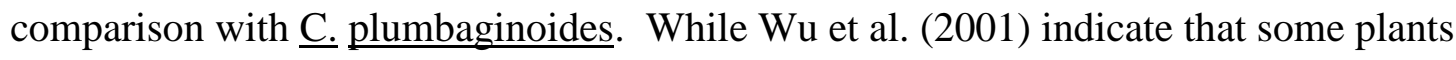
with higher thresholds for salt tolerance tend to accumulate less salt than plants with lower thresholds for salt tolerance, the Niu and Rodriguez (2006 a) experiment confirmed that certain salt tolerant plants can contain higher concentrations of salts without showing signs of salt damage.

Plant roots have the ability to limit or exclude uptake of salts better than plant leaves (Miyamoto, 2006). For this reason, irrigation practices can be manipulated to reduce damage on the leaf surface. Plants are usually damaged at lower salt concentrations when recycled water is applied to the foliage as opposed to the soil (Costello et al., 2003). An experiment by Wu et al. (2000-2001) compared sprinkler irrigation to drip irrigation to determine the reaction plants have to these two irrigation techniques. Selected woody plant species and native grasses were tested over a six week period, under different levels of $\mathrm{NaCl}$ as well as two different irrigation methods (Table 3). 
Table 3: Chemical Properties of Field and Container Soils After 6 weeks of Irrigation with Sprinkler and Drip Systems and Three Salt Concentrations. (from Wu et al. 2000-2001)

\begin{tabular}{|c|c|c|c|c|c|c|}
\hline Irrigation Method & Salt Treatment & Planting & $\mathrm{EC}$ & $\mathrm{pH}$ & $\mathrm{Cl}$ & $\mathrm{Na}$ \\
\hline Sprinkler & $\begin{array}{c}\text { Control } \\
500 \\
1500\end{array}$ & Field & $\begin{array}{l}0.63 \\
0.98 \\
2.08\end{array}$ & $\begin{array}{l}6.70 \\
6.85 \\
6.73\end{array}$ & $\begin{array}{c}71 \\
384 \\
1201\end{array}$ & $\begin{array}{c}45 \\
209 \\
794\end{array}$ \\
\hline Sprinkler & $\begin{array}{l}\text { Control } \\
500 \\
1500 \\
\end{array}$ & Container & $\begin{array}{l}0.32 \\
1.20 \\
1.81\end{array}$ & $\begin{array}{l}7.11 \\
7.02 \\
7.01\end{array}$ & $\begin{array}{c}44 \\
794 \\
1479\end{array}$ & $\begin{array}{c}22 \\
253 \\
757\end{array}$ \\
\hline Drip & $\begin{array}{l}\text { Control } \\
500 \\
1500\end{array}$ & Field & $\begin{array}{l}0.32 \\
1.18 \\
2.48\end{array}$ & $\begin{array}{l}6.70 \\
6.47 \\
6.80\end{array}$ & $\begin{array}{c}80 \\
416 \\
1356\end{array}$ & $\begin{array}{c}59 \\
314 \\
823\end{array}$ \\
\hline Drip & $\begin{array}{l}\text { Control } \\
500 \\
1500\end{array}$ & Container & $\begin{array}{l}0.30 \\
1.21 \\
2.30\end{array}$ & $\begin{array}{l}6.50 \\
7.05 \\
6.80\end{array}$ & $\begin{array}{c}62 \\
749 \\
1127\end{array}$ & $\begin{array}{c}31 \\
244 \\
755\end{array}$ \\
\hline \multicolumn{7}{|c|}{$\begin{array}{l}\text { Salt Treatment }=\left(\mathrm{mgL}^{-1}\right) \\
\mathrm{EC}=\left(\mathrm{dSm}^{-1}\right), \\
\mathrm{Cl}^{-} \text {and } \mathrm{Na}^{+}=\left(\mathrm{mg} \mathrm{kg}^{-1}\right)\end{array}$} \\
\hline
\end{tabular}

As plants were exposed to increased salt levels in the soil throughout the experiment, an increase in $\mathrm{EC}_{\mathrm{e}}$ was evident in all samples, as expected. The important finding in the test, however, was that although $\mathrm{EC}_{\mathrm{e}}$ levels for drip irrigated soils were actually higher than that of sprinkler irrigated soils, plants showed greater stress symptoms in sprinkler irrigated samples, while no symptoms were found in drip irrigated samples. Of the 38 plant species and 10 native grasses irrigated by sprinklers, only 12 $(31 \%)$ and $5(50 \%)$ respectively, were tolerant at the highest salt treatment $\left(1500 \mathrm{mgL}^{-1}\right)$. At the lowest salt treatment $\left(500 \mathrm{mgL}^{-1}\right)$ only 21 woody species $(55 \%)$ and $7(70 \%)$ native grasses were tolerant, while for drip irrigated treatments, no salt stress symptoms were found and all plants were tolerant at any treatment levels. Miyamoto (2006) showed that leaf morphology according to Miyamoto (2006) is a big determinant of plants salt adsorption through foilage from overhead irrigation practices. 


\section{Effect of Foliar and Root Absorbed Salts on plants}

Foliar and root absorption symptoms on plants vary slightly based on the degree of salt exposure, and on the sensitivity of the plant species. Foliar absorbed salt stress symptoms in broad leaf plants include marginal necrosis, defoliation, premature fall coloration and delayed spring leaf-out. Conifers absorbing salt through their needles show reddish-brown discoloration from the leaf tips working down the as they get darker brown before abscising (Figure 1a). Buds, twigs, branches or in more severe cases, the entire plant can die. For root absorbed salt stress, plants will exhibit leaf chlorosis and necrosis, with defoliation quickly following. Leaf tips and margins of the oldest leaves are the location for this stress symptom in broadleaf plants (Figure 1b), while in conifers yellowing of needles is the first symptom proceeding a brown discoloration from the tip down, before defoliation occurs (Costello et al 2003).

1a. Foliar Absorbed Salt Damage

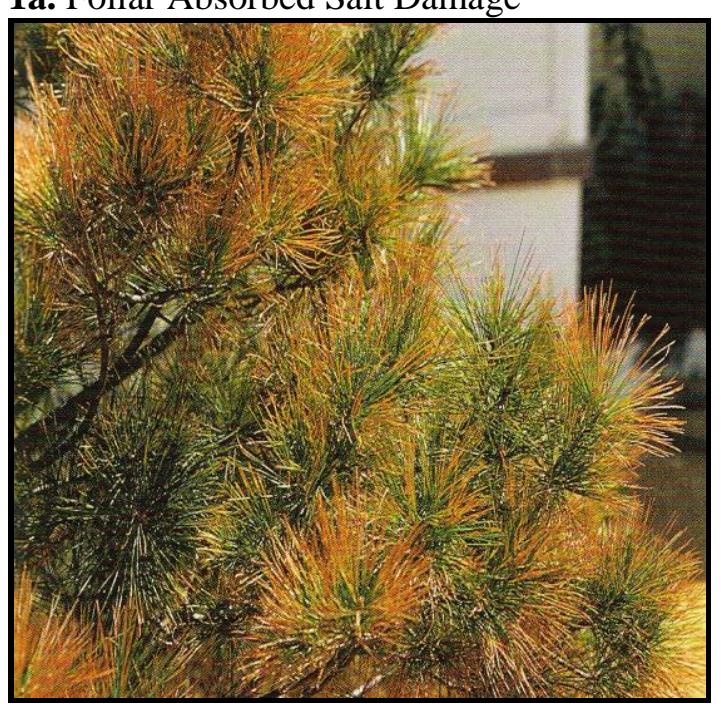

1b. Root Absorbed Salt Damage

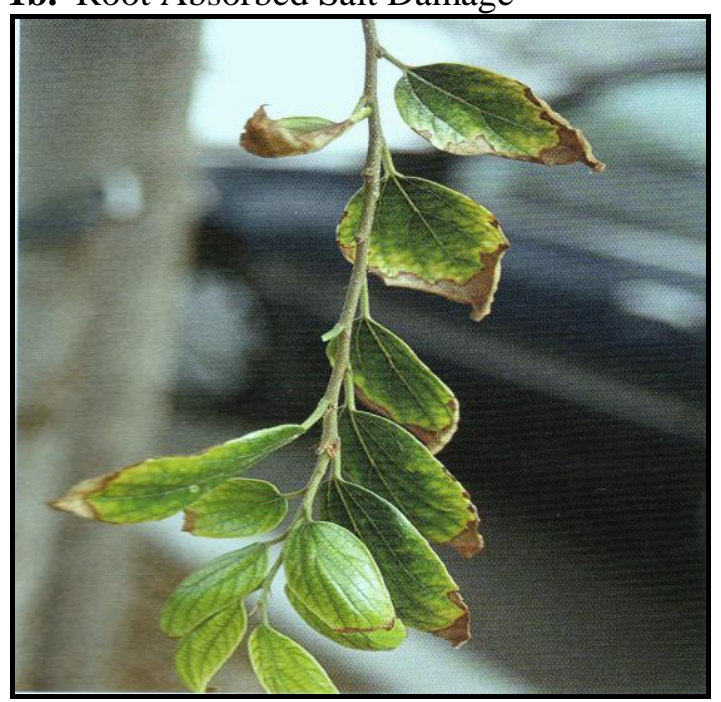

Figure 1. Root and Foliar Absorbed Salt Damage (From Costello et al., 2003) 


\section{$\underline{\text { Environmental Factors influencing Salt Accumulation }}$}

Environmental factors such as temperature and the precipitation frequency influence the amount of salts that accumulate in the soil. The extent of salt accumulation in the soil also depends on the concentration of salts in the irrigation water, and the rate at which salts are removed by leaching (USEPA, 2004). As temperature increases, effective precipitation levels decrease due to evaporation factor; thus, leaving an accumulation of salt in the soil. In Mediterranean climates, October salinity levels were at their highest for all treatments in an experiment by Wu et al. (2000-2001) and at their lowest in spring months after rain cessation. Since arid regions have low precipitation rates, salts accumulate in the upper soil zones where plant roots are located. The insufficient amount of precipitation prevents the leaching of salts from these crucial upper soil zones (Brady and Weil, 2008).

On the other hand, if irrigation with high salt recycled water is too frequently applied to the soil; harmful salts accumulate and can have detrimental effects on soil properties and plant physiology. As noted by Brady and Weil (2008), in dry climates salts usually become more of a problem when too much water is supplied, not too little. As a result, it is essential that recycled irrigation water be processed and managed to allow adequate leaching of salts from the root zone (Bonds, 1998). The media leachate in the experiment by Niu and Rodriguez (2006b) was tested and found to have a higher salinity than the water applied to the soil, proving that when proper leaching occurs, salts are leached from the root zone. 


\section{pH Effect on Soil Characteristics}

Soil $\mathrm{pH}$ has an effect on plant nutrition as the availability of certain macro and micro-nutrients essential for plant growth becomes limited when soil $\mathrm{pH}$ is compromised (Costello et al., 2003; Brady and Weil, 2008; Taiz and Zeiger, 2006). The unavailability of one or more of these essential nutrients due to an increase or decrease in $\mathrm{pH}$ can have significant effects on most plants. Recycled water typically has $\mathrm{pH}$ levels that are alkaline. When soils' alkalinity increases (greater than 7.5), iron, manganese, zinc, and copper become unavailable for plant use (Brady and Weil, 2008) (Figure 2) and a saline condition is also created. As soils $\mathrm{pH}$ reach greater than or equal to 8.5 , they become sodic and can become directly toxic to plants. Secondary problems affected by soil $\mathrm{pH}$ include changing the population and activity of soil microorganisms, which affect the root cell function, particularly in regards to water, and nutrient uptake (Costello et al. 2003 and Brady and Weil, 2008). Although some plants can survive, or even thrive in conditions where $\mathrm{pH}$ levels are above or below the optimal range, most plants flourish in a more neutral environment. 


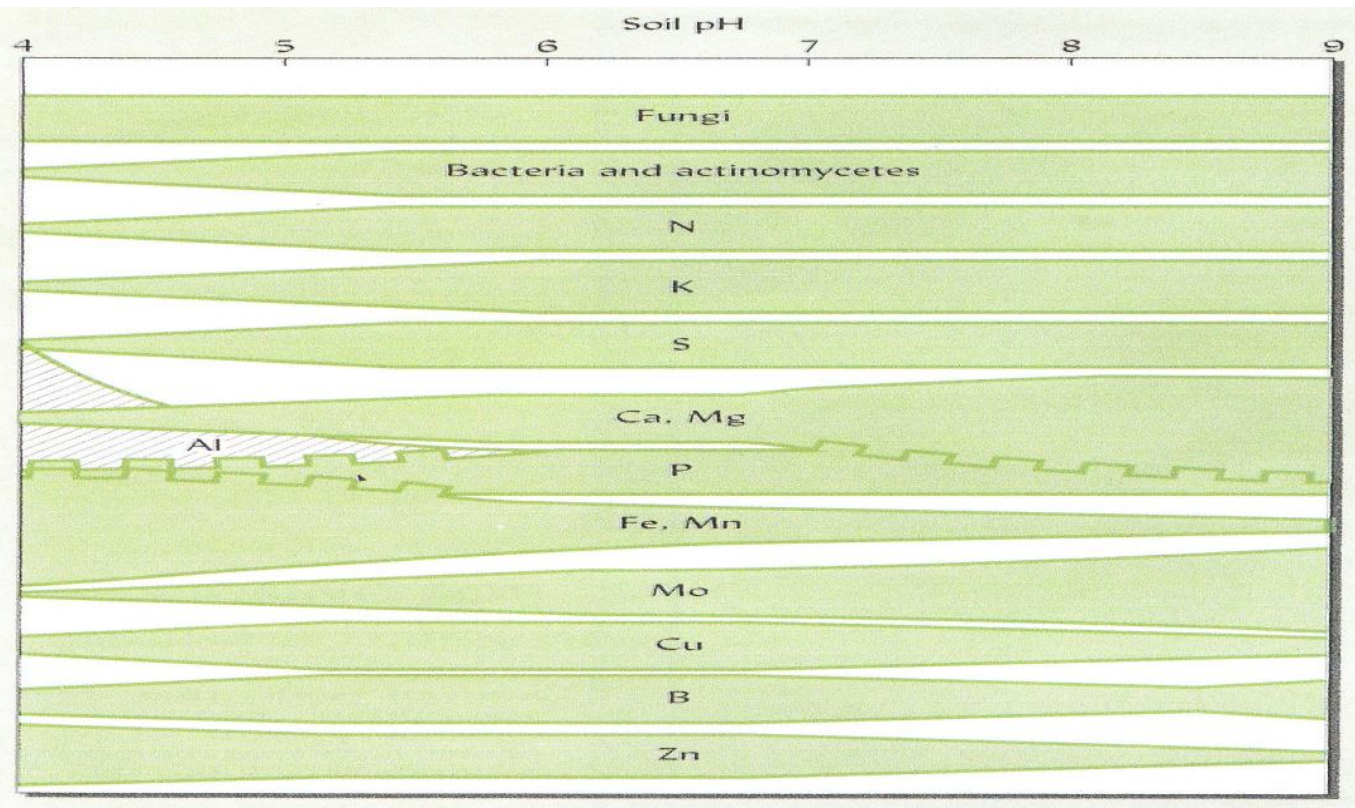

Figure 2: Availability of Nutrients at Different pH Levels (Excerpted from Brady and Weil, 2008 p.385)

\section{pH Symptoms on Plants}

The availability of specific nutrients such as iron, zinc, and manganese can be minimized when soil pH increases above 7.5 (Costello et al., 2003 and Brady and Weil, 2008). Therefore, recycled water that increases the soil $\mathrm{pH}$ may cause many stress symptoms in plant leaves with varying patterns of chlorosis. A deficiency in iron will cause interveinal chlorosis with narrow bands of green on and along the veins (Figure 3a). As iron is immobile in plants, older basal leaves remain green while young leaves become chlorotic. Zinc deficiency causes a mottled chlorosis pattern with abnormally small leaves and internodes (Figure 3b), while manganese deficiency causes new leaves to become yellow with wide green bands along the veins (Figure 3c) and leaves in certain species of plants have been known to have wavy crinkled or curled leaf margins (Costello et al., 2003). 


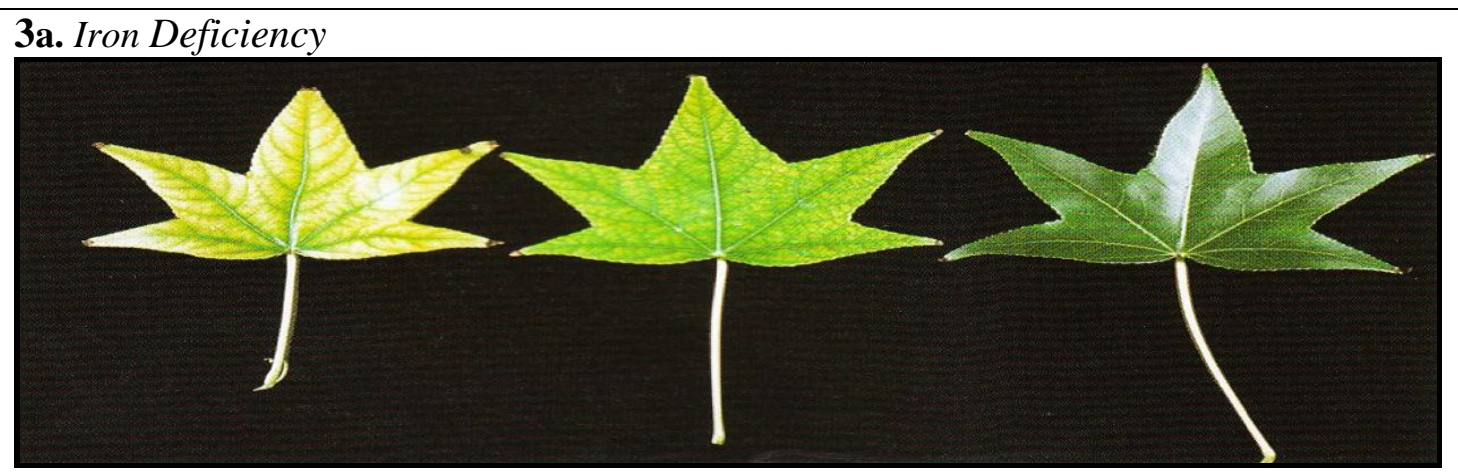

\section{3b. Zinc Deficiency}

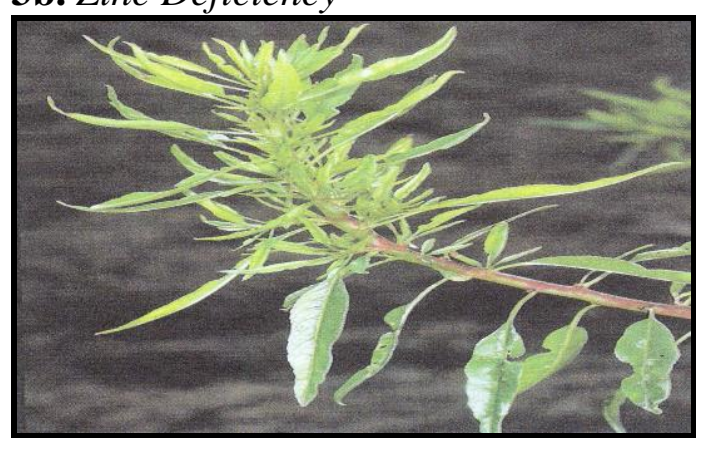

3c. Manganese Deficiency

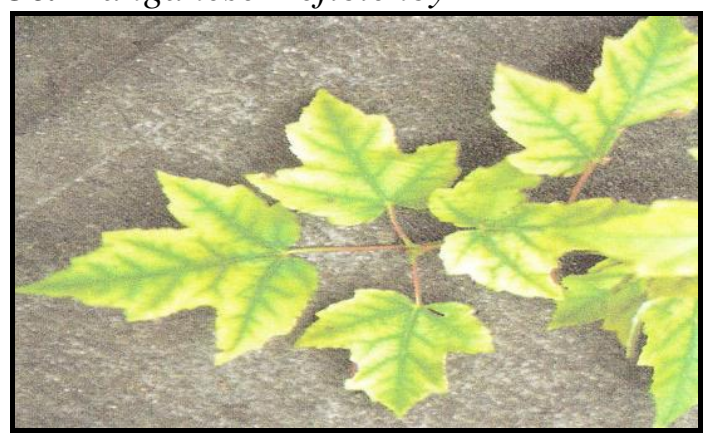

Figure 3: Nutrient Deficiency Symptoms (Excerpted from Costello et al., 2003)

An experiment by Lubello et al. (2004) demonstrated the effect recycled water had on growth and aesthetics of selected plants. The mean $\mathrm{pH}$ of recycled effluent water was 7.5, in Pistoia, Italy and was much higher in comparison to the potable water from a well source which was 6.76 (Table 4). In this experiment, a nutrient deficiency, most likely caused by $\mathrm{pH}$ changes in the recycled water, caused one of the six species of trees and shrubs (Arbutus spp.) to show major stress symptoms and a decrease in overall growth. The reduction in growth in this experiment was measured by destructively harvesting the plants and taking the leaf area, as well total plant weight of shoots and roots. Data in Table 4 shows the results from this experiment which reveal that, other than Arbutus spp., all of the other plants produced steady growth or no reaction when 
irrigation was changed from potable, to recycled water. These findings show that with the exception of salt sensitive plants, there were no limitations to the use of recycled water in this region, and the nutrient content of the irrigation water maintained good plant growth. The author attributes the positive reaction by certain plants to the amounts of nitrogen content in the water and the negative effects of recycled water to species' sensitivity to salt.

Table 4: Contrast and Effect of Potable and Recycled Water on Selected Plants (Lubello et al., 2004) (Redrawn)

\begin{tabular}{|c|c|c|c|c|}
\hline Treatment & $\frac{\text { Dry }}{\text { Root }}$ & Shoot & $\frac{\text { Matter }(\mathbf{g})}{\text { Total }}$ & Leaf Area $\left(\mathrm{cm}^{2}\right)$ \\
\hline $\begin{array}{l}\text { Arbutus } \\
\text { Potable } \\
\text { Recycled Water }\end{array}$ & $\begin{array}{l}59.52 \\
29.83 \\
\end{array}$ & $\begin{array}{l}7.96 \\
7.06 \\
\end{array}$ & $\begin{array}{l}67.48 \\
36.89 \\
\end{array}$ & $\begin{array}{c}13.06 \\
9.08 \\
\end{array}$ \\
\hline $\begin{array}{l}\text { Cypress } \\
\text { Potable } \\
\text { Recycled Water }\end{array}$ & $\begin{array}{l}32.17 \\
28.57\end{array}$ & $\begin{array}{l}5.59 \\
7.24\end{array}$ & $\begin{array}{l}37.76 \\
35.81\end{array}$ & $\begin{array}{l}- \\
-\end{array}$ \\
\hline $\begin{array}{l}\text { Juniper } \\
\text { Potable } \\
\text { Recycled Water }\end{array}$ & $\begin{array}{l}34.77 \\
35.43 \\
\end{array}$ & $\begin{array}{c}7.66 \\
13.92\end{array}$ & $\begin{array}{l}42.43 \\
49.35 \\
\end{array}$ & - \\
\hline $\begin{array}{l}\text { Myrtle } \\
\text { Potable } \\
\text { Recycled Water }\end{array}$ & $\begin{array}{l}66.56 \\
58.65 \\
\end{array}$ & $\begin{array}{l}14.02 \\
18.57 \\
\end{array}$ & $\begin{array}{l}80.58 \\
77.22 \\
\end{array}$ & $\begin{array}{l}2.49 \\
2.30 \\
\end{array}$ \\
\hline $\begin{array}{l}\text { Spirea } \\
\text { Potable } \\
\text { Recycled Water }\end{array}$ & $\begin{array}{c}15.01 \\
8.90\end{array}$ & $\begin{array}{l}16.00 \\
18.23\end{array}$ & $\begin{array}{l}31.01 \\
27.13\end{array}$ & $\begin{array}{l}2.30 \\
2.28\end{array}$ \\
\hline $\begin{array}{l}\text { Weigelia } \\
\text { Potable } \\
\text { Recycled Water }\end{array}$ & $\begin{array}{l}17.35 \\
16.70\end{array}$ & $\begin{array}{l}19.54 \\
18.02\end{array}$ & $\begin{array}{l}36.89 \\
34.72 \\
\end{array}$ & $\begin{array}{l}15.54 \\
12.19\end{array}$ \\
\hline
\end{tabular}




\section{Sodium Adsorption Ratio (SAR)/ Exchangeable Sodium Percentage (ESP)}

Sodium Adsorption Ratio (SAR) and Exchangeable Sodium Percentage (ESP) are two measurements used to characterize the sodium status of soils, although SAR is the most widely used measurement. The reason for this is that SAR compares the

concentrations of $\mathrm{Na}^{+}, \mathrm{Ca}^{2+}$, and $\mathrm{Mg}^{2+}$ (Eq. 1) whereas ESP compares exchangeable sodium to the cation exchange capacity (Eq. 2) (Brady and Weil, 2008 and Halliwell et al., 2001).

$$
\mathrm{SAR}=\left[\mathrm{Na}^{+}\right] \div\left(0.5\left[\mathrm{Ca}^{2+}=\right]+0.5\left[\mathrm{Mg}^{2+}\right]\right)^{1 / 2}
$$

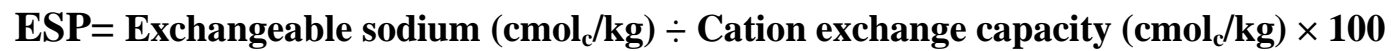

A soil SAR value should be less than 6.0 in soil to be in the general safe zone for a majority of plants (Table 1). The ESP value should be below 15. Soils that exceed these thresholds usually have severely deteriorated physical properties and $\mathrm{pH}$ values of 8.5 and above (Brady and Weil, 2008 and Costello et al., 2003). Figure 4 describes the relationship SAR and ESP have with $\mathrm{EC}_{\mathrm{e}}$, these relationships help to measure salt affected soils and the threshold capability of certain salt tolerant plants. As SAR/ESP increases in soil and decreases in EC, $\mathrm{pH}$ increases and sodic soil conditions are created. On the other hand, when EC increases in the soil and SAR/ESP decreases, saline soil conditions are created. 

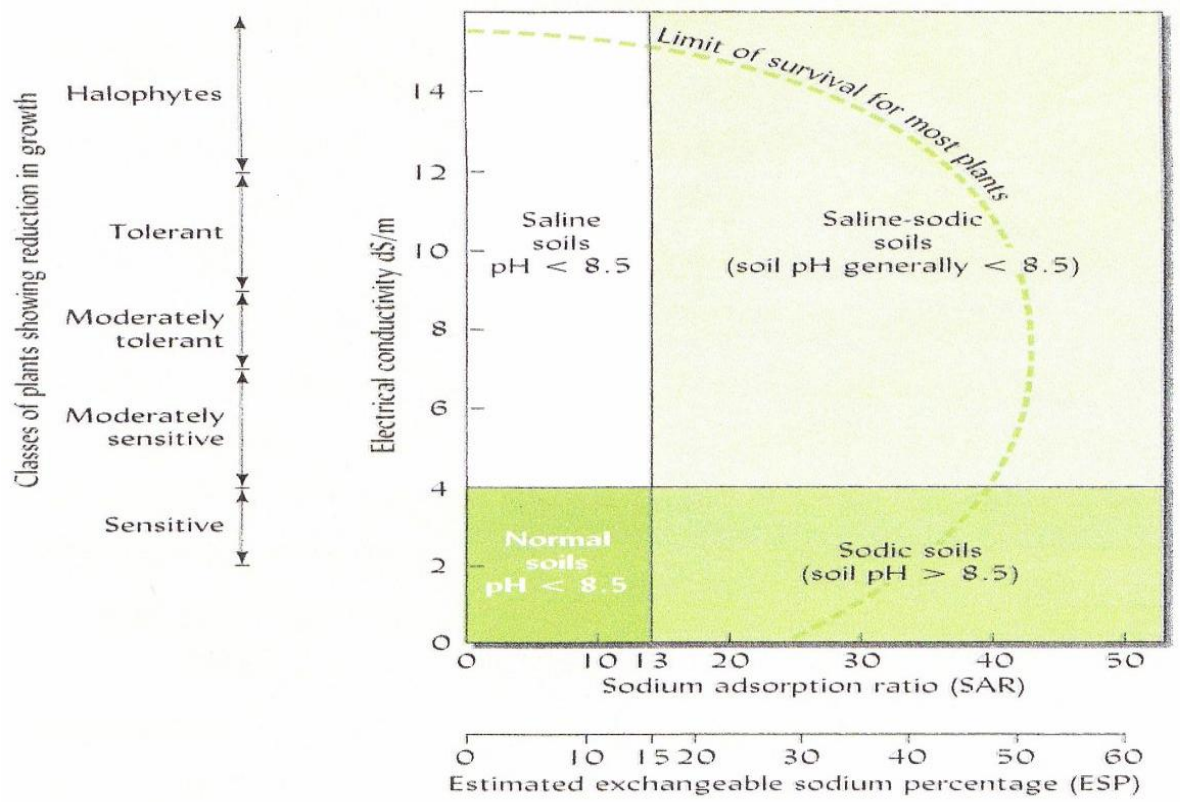

Figure 4: Relationship of salt affected soils to pH, EC, SAR and ESP (Brady and Weil 2008 p.419) Class of Soils in relation to $\mathbf{p H}, \mathbf{E C}, \mathbf{S A R}$ and ESP

\section{Types of Salt-Affected Soils and Their Effect on Plants}

\section{$\underline{\text { Saline Soils }}$}

Using EC, SAR and/or ESP, and soil pH, classification of salt affected soils can be determined (Figure \#3). When soils are not highly affected by salts they are considered normal (Brady and Weil, 2008). Normal soils have $\mathrm{EC}_{\mathrm{e}}$ less than or equal to 4dSm, ESP less than or equal 15, and a SAR less than 13. Soils that contain high concentrations of salt are classified as saline soils, and these soils are formed when water with high salinity is added to the growing media over a period of time under high evaporative demand, and/or when soil drains poorly (Costello et al., 2003). When soils contain sufficient salts to give $\mathrm{EC}_{\mathrm{e}}$ values greater than $4 \mathrm{dS} / \mathrm{m}$ and $\mathrm{SAR}$ of less than 13 
(ESP less than 15) the soils are considered saline. Saline soils have a soil $\mathrm{pH}$ that is below 8.5 and high levels of salt, mainly calcium and magnesium, which dominate the exchange complex (Brady and Weil, 2008). Recycled water with properties that are saline in nature will not prevent plant growth in tolerant species unless the high EC prevents adequate water uptake by plants. Soluble salts in saline soils may help prevent the dispersion of soil; providing adequate aeration, and therefore, and stabilize soil aggregates (Brady and Weil, 2008). Plants that are moderately salt tolerant to tolerant typically are unaffected by the salts in saline soils (Brady and Weil, 2008). Salt sensitive plants that do experience problems from the saline soils and saline irrigation, however, will exhibit stunted growth, chlorosis, leaf tip and marginal burn, defoliation, and/or death.

\section{$\underline{\text { Saline-Sodic Soils }}$}

Soils that contain salts and high levels of exchangeable sodium are considered saline-sodic according to Brady and Weil (2008) and Costello et al. (2003). These soils contain characteristics of both saline and sodic soils, having $\mathrm{EC}_{\mathrm{e}}$ greater than $4 \mathrm{dSm}$ (from high concentrations of soluble salts) and ESP greater than 15, and a SAR measurement greater than 13 (from high sodium concentrations). Many of the properties of recycled water can create saline-sodic soils. Saline-sodic soils contain soluble salts (calcium and magnesium), that act as stabilizing ions and actually prevent the dispersion of soil aggregates caused by high concentrations of sodium, a destabilizing ion. Moderately tolerant plant species and tolerant plant species are capable of surviving and 
developing at both high levels of ESP and EC because of the balance of other salts to sodium.

Plants classified as sensitive in saline-sodic conditions will show stunted growth, chlorosis, necrosis, and death. The soils could have white or black crust on the surface, and ponding on the soil surface could be present after irrigation with recycled water (Costello et al., 2003). According to Figure 4 moderately sensitive, moderately tolerant, and tolerant plants can survive in this type of soil. The problem with saline-sodic soils is that when soluble salts are leached from the soil using recycled water sodium can accumulate in the root zone, and can cause the soil to change from saline-sodic to sodic.

\section{$\underline{\text { Sodic Soils }}$}

Soils that are high in exchangeable sodium (ESP 15 and SAR 13) but contain low soluble salts (ECe less than $4 . \mathrm{dS} / \mathrm{m}$ ) are considered sodic soils. Sodic soils can be caused by high levels of sodium found in recycled water and that have $\mathrm{pH}$ levels above 8.5 due toNa $\mathrm{CO}_{3}+\mathrm{NaHCO}_{3}$ (Brady and Weil, 2008 and Costello et al., 2003). The poor structure of sodic soils causes a decrease in water and air permeability, therefore reducing drainage. According to Bond (1998), plants may show minimal problems during periods where soils are irrigated with recycled water containing high sodium and low salts, although once the use of effluent irrigation is stopped, detrimental effects of sodicity become noticeable. Plants growing in these conditions may show signs of stunted growth, chlorosis, necrosis and death. Also, soil may have a white or black crust on the surface and standing water on the soil surface from poor permeability (Costello et al., 2003). 


\section{Effects of Osmotic Potential and Ion Toxicity on Plants From Salt-Affected Soils}

Other than soil degradation, osmotic potential and ion toxicity are two conditions that can affect plant growth and aesthetics from salinity in recycled water (USEPA, 2004). Osmotic potential is a measure of water's attraction to salts and affects the ability of roots to uptake water from the soil and supply it to plants. Niu and Rodriguez (2006 a) showed that as salinity increased $\left(\mathrm{EC}=0.8,3.2,6.4 \& 12.0 \mathrm{dS} \mathrm{m}^{-1}\right)$ there was a decrease in osmotic potential in all plants. Control plants irrigated with low EC potable water had higher osmotic potential than all plants irrigated with saline treatments. Although the decrease in osmotic potential was detrimental to some of the plants tested, Niu and Rodriguez (2006a) found that osmotic adjustment is a mechanism in salt tolerance, and in

all species tested (even the ones that died) each had some amount of osmotic adjustment. These osmotic adjustments require plants to expend more energy to lower the osmotic potential inside their cells in the process of accumulating organic and inorganic solutes. This, in turn, compensates for the lower osmotic potential in the soil. The result is a reduction of growth in the plant (Brady and Weil, 2008).

Some plants tolerate salt stress by avoiding absorbing certain toxic ions or by tolerating certain ionic concentrations in the tissue (Niu and Rodriguez, 2006a). The type of salt, or ion, and the species of plant determines how the plants respond to salinity. Ions such as sodium and chloride are the most abundant in recycled water (Wu et al., 20002001) and quite toxic to plants at high concentrations (Brady and Weil, 2008). Since sodium competes with the essential nutrient potassium $\left(\mathrm{K}^{+}\right)$, high levels of sodium make it difficult for plants to obtain the amounts of $\mathrm{K}^{+}$they need, especially in harsh soil conditions (Brady and Weil, 2008). The SAR demonstrates the importance of the 
relationship between sodium to calcium and magnesium in determining soil balance. Calcium and magnesium help to counteract the effects of sodium, thus balancing the concentrations of the ions.

The experimental data in Tables 2 and 3 show the level of specific ionic concentration after different salinity treatments. The two important findings in these experiments revealed that the amount of specific ion uptake in plants varied from species to species and that sodium and chloride were most abundant in all of the samples.

\section{Sodium}

According to Toze (2006), the salinity of recycled water is directly affected by the concentration of sodium. For this reason, salinity in the form of sodium can directly affect soil properties through soil swelling and dispersion (Halliwell et al., 2001). In simplest terms, exchangeable sodium increases the tendency of soil aggregates to break apart when wet. When this happens, the clay and silt soil particles are washed into the soil profile and eventually clog soil pores. Swelling occurs in soils containing expanding clays, where, as the saturation of sodium increases the degree of swelling increases. As clay swells, it decreases the ability of large pores to drain water. When high sodium concentrations and low total dissolved salt concentrations are present, the result is soil dispersion (Brady and Weil, 2008).

Water permeability, and therefore, soil drainage is measured by hydraulic conductivity the velocity at which water moves through the soil profile. Increased ESP and decreased hydraulic conductivity, causes water to remain on the surface causing ponding, resulting in reduced levels of water essential for plant growth (Toze, 2005). An 
analysis of Figure 5 shows this the relationship that ESP has with saturated hydraulic conductivity.

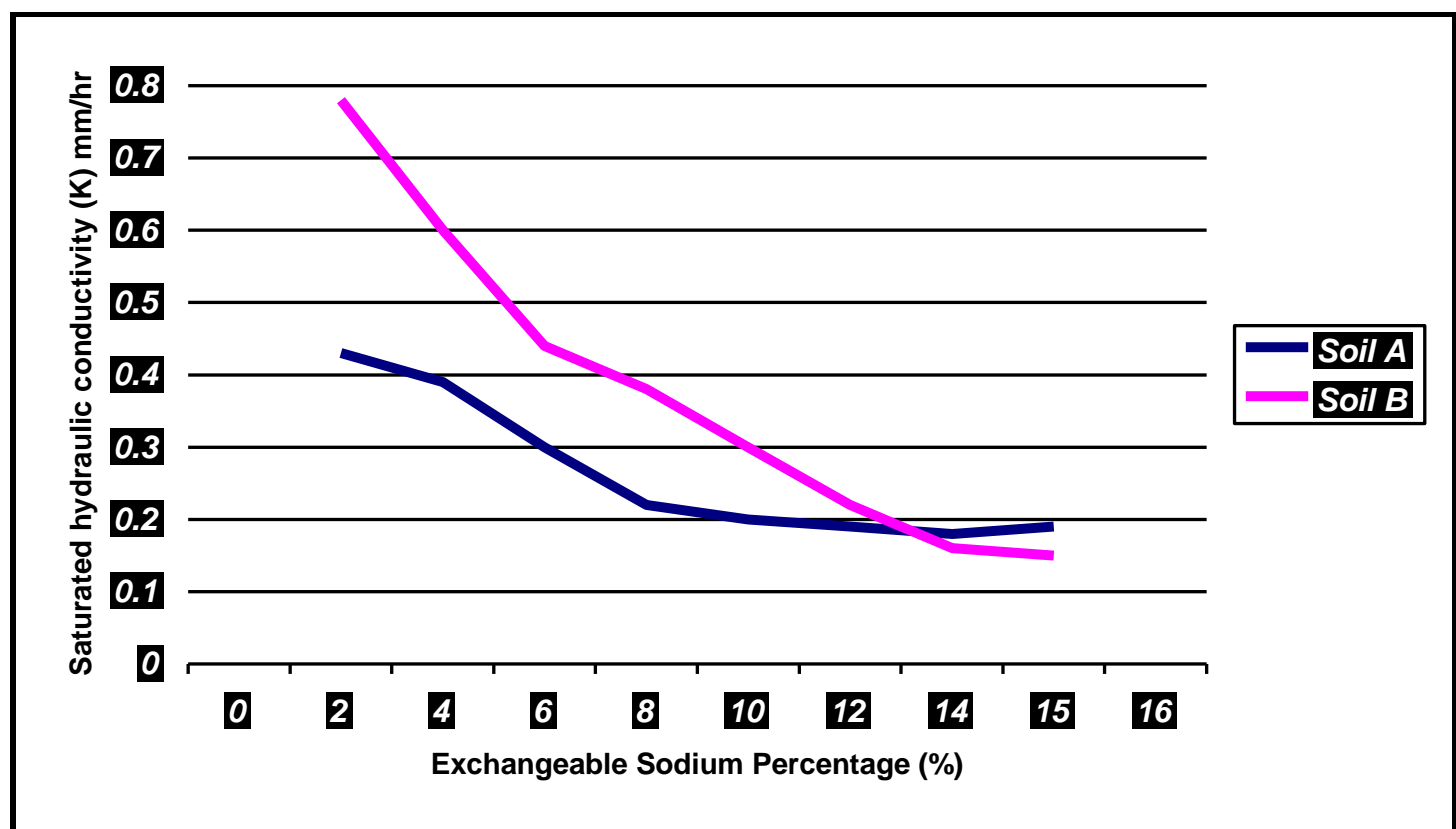

Figure 5: Relationship between ESP and Hydraulic Conductivity (Brady and Weil, 2008)

Since plant roots absorb sodium and transport it to leaves, sodium can accumulate and cause leaf injury. Although sodium can be directly toxic to plants, its most harmful effects are indirect; mainly effecting soil structure (Harivandi, 2004). Therefore, sodium does not impair the uptake of water by plant roots but rather effects soil percolation and water availability to plants. Plants suffering from excess sodium in the soil will exhibit mottled and interveinal chlorosis (Figure 6), progressing to the leaf tips, necrotic margins, and interveinal damage (Costello et al., 2003). These symptoms appear first and most severely on oldest leaves because to transpiring water accumulates salts over a period of time (Brady and Weil, 2008). 


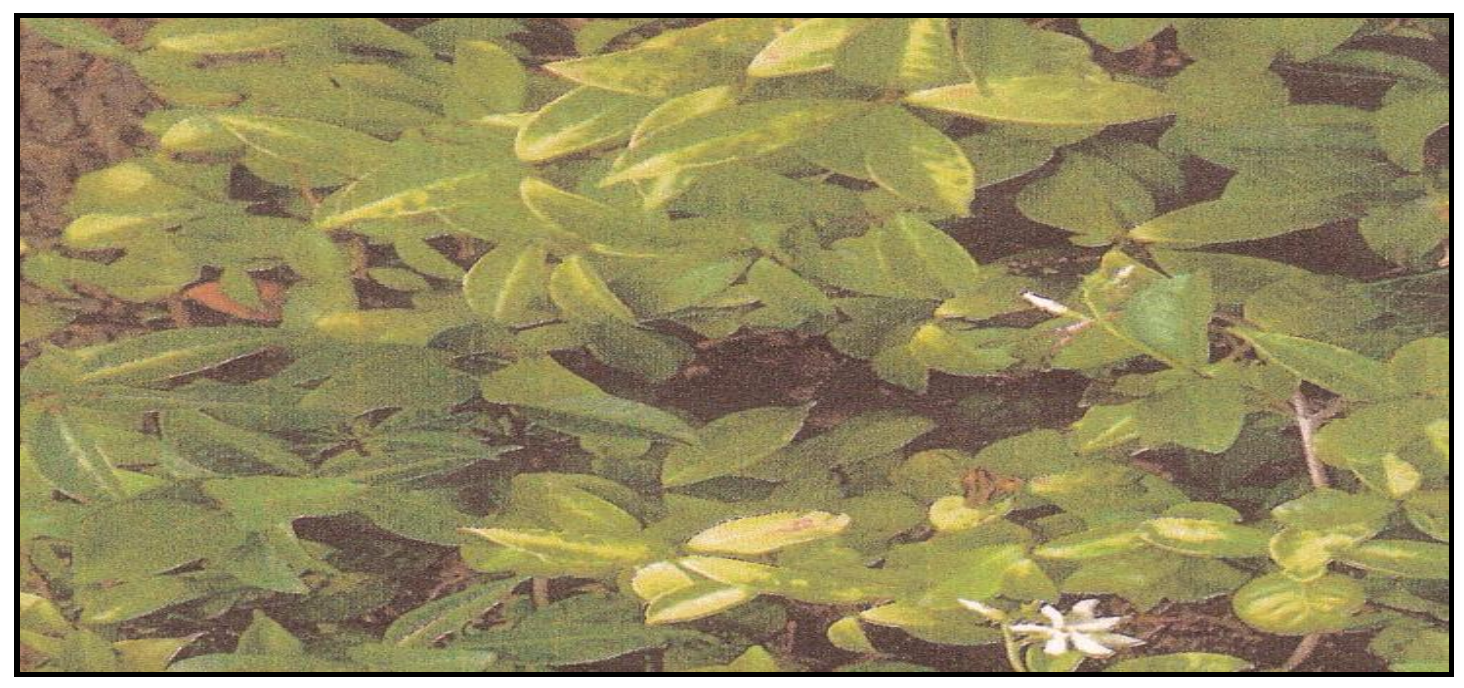

Figure 6: Sodium Toxicity (Costello et al. 2003 p.84)

\section{Chloride}

In addition to contributing to the total soluble salt concentration of irrigation water, chloride can be directly harmful to plants when it is absorbed by the roots, transported to leaves, and accumulates in leaf tissue (Harivandi, 2004). The accumulation of chloride in sensitive plants leads to reduced leaf size, and slower growth rate, necrosis of leaf tips or margins, bronzing, premature yellowing and abscission of leaves and chlorosis (Figure 7a and 7b) (Costello et al., 2003 and Harivandi, 2004). Chloride is extremely soluble and is easily leached, however, as levels of chloride become greater than $250 \mathrm{mg} / \mathrm{L}$ in the soil and greater than $350 \mathrm{mg} / \mathrm{L}$ in recycled water, sensitive plants will become damaged (Pettygrove and Asano 1985). Depending on the source from which recycled water is collected and distributed, chloride is usually below the harmful detectable limits (Lubello et al., 2004). 


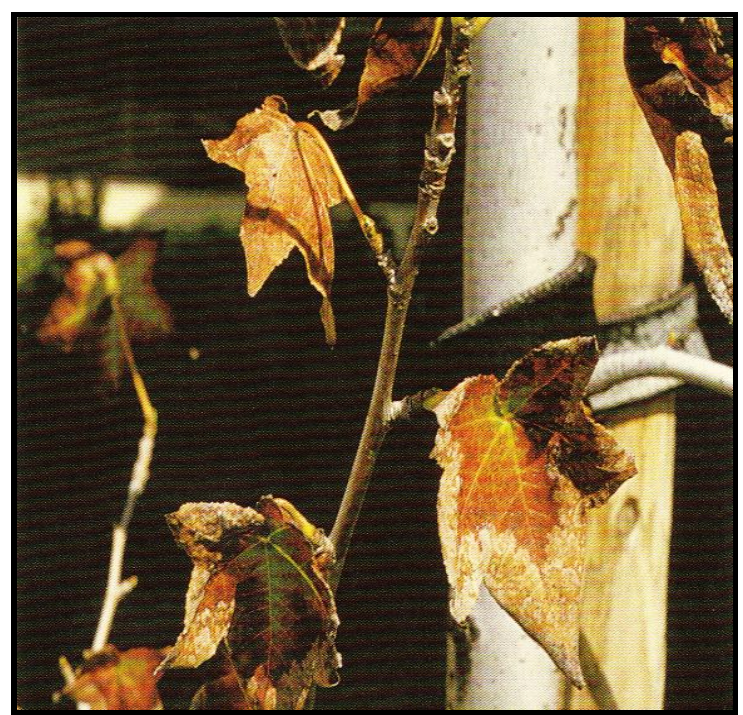

a.

Figure 7: a. Choride Toxicity (Sweetgum) and b. Chloride Toxicity (European hackberry) (Costello et al. 2003)

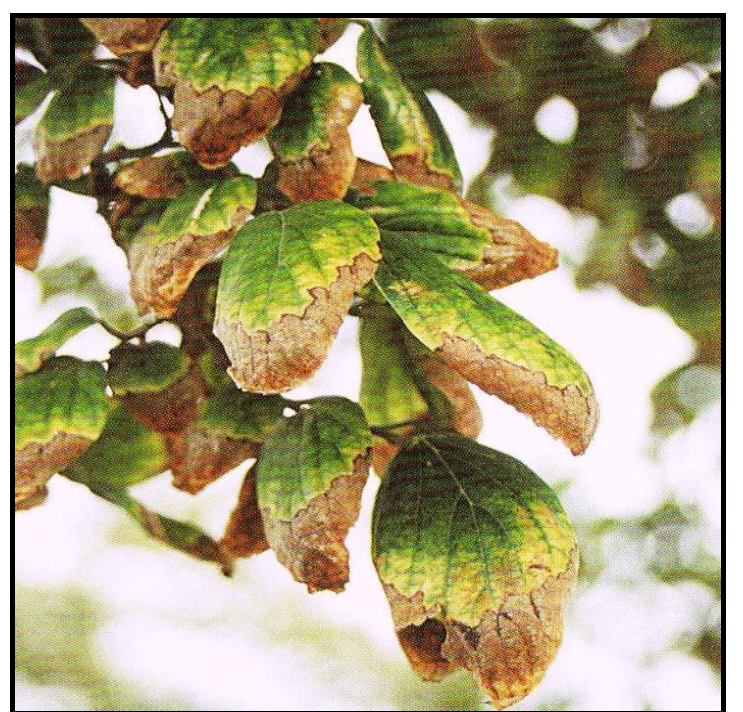

b.

\section{The Effect of Recycled Water on Turfgrasses}

Turfgrasses, like ornamental plants, play an important role in many landscapes. Golf courses throughout the United States have increased the use of recycled water irrigation, thus requiring new considerations and strategies for turfgrass management. Since recycled water contains levels of mineral salts and chemicals, determining the benefit of the recycled water is important. Many soluble salts are beneficial to the development and growth of turf, but other salts can be toxic at high concentrations (Harivandi, 2004). While turfgrasses differ from ornamental plants in their response to recycled water irrigation, a characteristic shared by both is the effect salts have when overhead sprinkler irrigation is applied overhead. Since roots can exclude the uptake of certain salts and toxic ions present in recycled water, irrigation techniques should be reconsidered and changes in water management should be employed. Although recycled 
water varies from different sources and can have harmful constituents, recent studies

have shown that salt levels in most recycled water are too low to cause stress on many grasses, which can tolerate up to $5000 \mathrm{mgL}^{-1}$. Table 1 is a comprehensive guide for managing acceptable parameters for salinity in recycled water and soil, in regards to turf grass. Salt tolerance of selected turfgrasses can be seen in Table 5.

\begin{tabular}{|c|c|c|c|}
\hline $\begin{array}{c}\text { Sensitive } \\
(<\mathbf{3 d S m - 1 )}\end{array}$ & $\begin{array}{c}\text { Moderately Sensitive } \\
(\mathbf{3 - 6} \text { dSm-1) }\end{array}$ & $\begin{array}{c}\text { Moderately Tolerant } \\
(\mathbf{6 - 1 0} \mathbf{d S m}-\mathbf{1})\end{array}$ & $\begin{array}{c}\text { Tolerant } \\
(>\mathbf{1 0} \mathbf{d S m}-\mathbf{1})\end{array}$ \\
\hline Annual Bluegrass & Annual Ryegrass & Perennial Ryegrass & Alkaligrass \\
\hline Colonial Bentgrass & Creeping Bentgrass & Tall Fescue & Bermudagrass \\
\hline Kentucky Bluegrass & Fine-leaf Fescues & Zoysiagrasses & Seashore Paspalum \\
\hline Rough Bluegrass & Buffalograss & & St. Augustinegrass \\
\hline \multicolumn{3}{|r}{}
\end{tabular}

Table \#5: The Relative Tolerances of Turf Grass Species to Soil Salinity (ECe). (From Harivandi et al. 1992)

\section{$\underline{\text { Conclusion }}$}

As the need to conserve freshwater resources increases, so does the pressure to use alternative methods of conservation to preserve the earth's most vital resource (Toze, 2005). With that said, there are many positive and negative factors to consider when using recycled water for irrigation as a water conservation practice. Although recycled water contains essential nutrients that can promote plant growth and development, it can also contain salts or other harmful elements that are detrimental to plant growth. Since recycled water can create an additional water resource for landscapers, the improper use and management of this new resource can damage soil properties and have a direct effect on landscape plants. Physiological differences among plant species make salt tolerance very species dependent. When landscape plants with vastly different salt tolerances are planted side by side and irrigated with recycled water, differential growth appears 
(Miyamoto, 2006). Therefore, the salt content in recycled irrigation water should be considered, along with combining species with similar salt tolerances in the areas of the landscape where this water may be used (Appendices 1-2)

Environmental conditions such as rainfall and temperature are additional factors that regulate the effect of recycled water on plants and in the soil. Areas with high precipitation rates leach harmful salts better than areas with lower precipitation rates. Therefore, some of the factors to consider when using recycled water to irrigate landscape plants are: salt tolerance of species, characteristics of recycled water from the source, characteristics of the growing media, and environmental conditions pertinent for growing plants. Planning for and recognizing these different factors can help practitioners avoid plant damage or stress. Using soil and water indices of salt concentrations such as $\mathrm{pH}, \mathrm{EC}, \mathrm{SAR}$ and/or ESP, management and strategic planning of sites can be closely monitored and manipulated. Overall results indicate that there are no major limitations to most irrigation uses of recycled water (Lubello et al., 2004). However, sources differ case by case and, therefore, should be examined before irrigation with RW is implemented. 


\section{$\underline{\text { Materials and Methods }}$}

\section{Phase I- Summer}

This project was conducted at the Paso Robles Waste Water Treatment Plant in Paso Robles, California from August 16, 2008- November 11, 2008. The officials in charge of managing the water plant provided sufficient resources for complete experimentation. These include: a graded area to perform the experiment, reclaimed irrigation water mainline and an irrigation clock, restricted animal fencing, and other personal resources to aid in the development and construction of this project. Materials purchased for this phase are listed in Appendix 3.

This site was located in Sunset Zone 7 characterized by dry summers and moist winters. Plants in this zone should be adaptable to hot summers and moderately cold winters. Figure 8 and Figure 9 show the average monthly temperatures and precipitation, as well as record high and low temperatures recorded in Paso Robles respectively. 
$\longrightarrow$ Record High Temp. $\rightarrow$ Average high Temp. $\rightarrow$ Average Low Temp. $\rightarrow$ Record Low Temp.

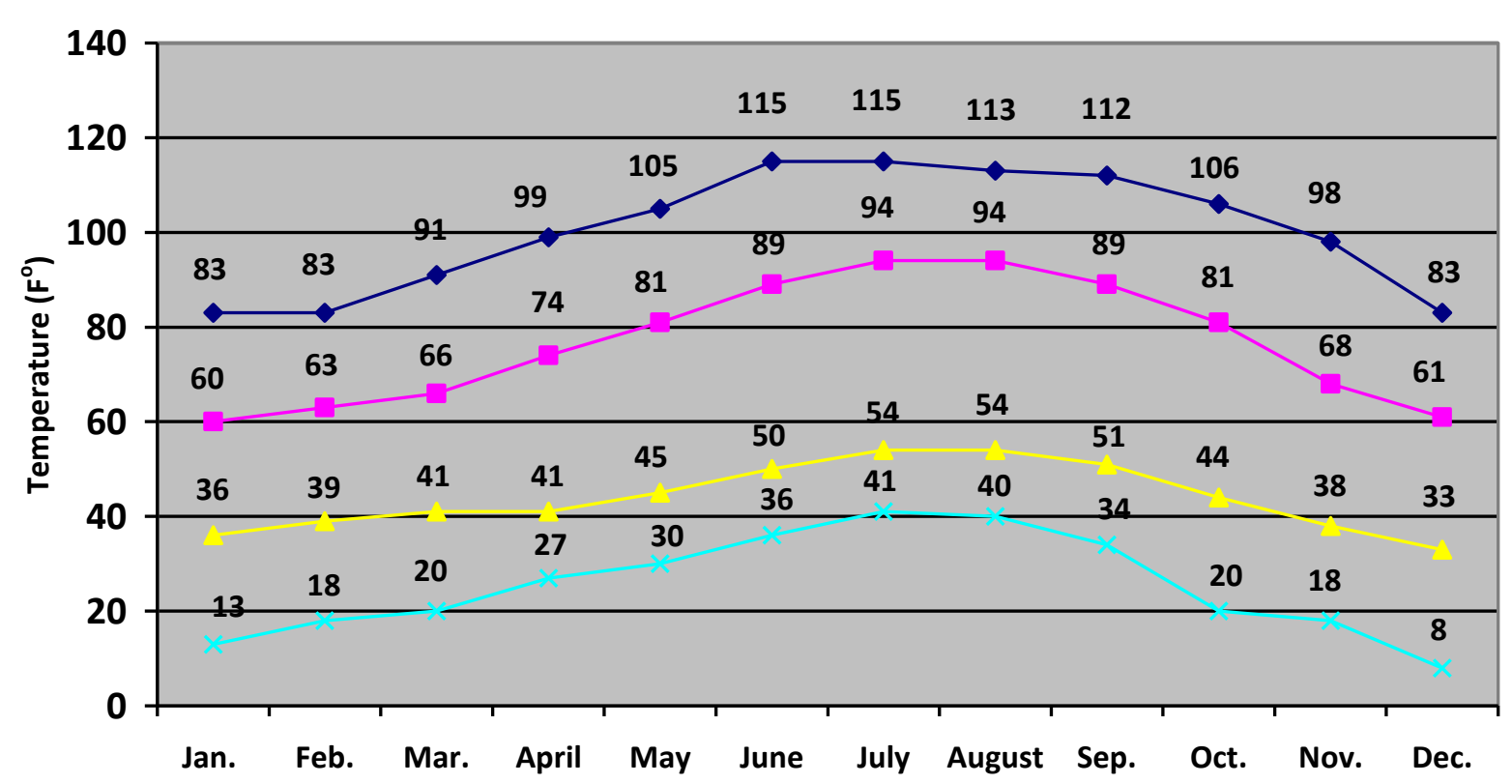

Figure 8: Average and Record Temperatures for Paso Robles, California (From http://www.weather.com/weather)

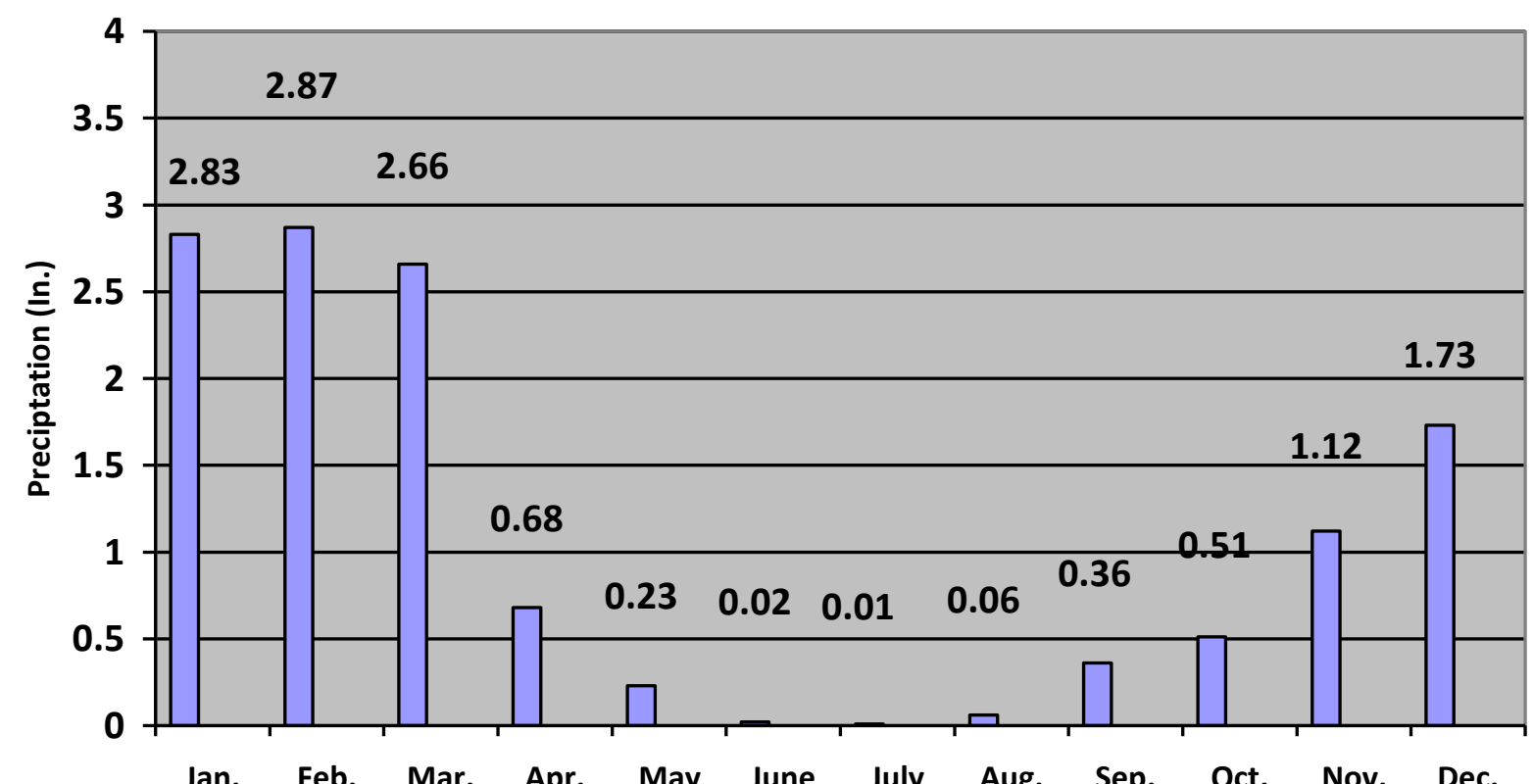

Figure 9: Average Precipitation for Paso Robles, California (From http://www.weather.com/weather) 
Plants for the first phase of this project were selected on the basis of their tolerance to the hot, dry summer heat (due to the summer growing season), tolerance to salt in irrigation water and soil, their popularity in landscapes throughout the Central Coast region of California, and their classifications as grasses, herbaceous perennials, shrubs, or annual plants. Figure 10 lists the plants that were selected for this experiment and their relative tolerance to salt.

All plants were purchased in Number 1 nursery containers, with exception of Gazania spp. and Osteospermum fruticosum, which were bought in flats and transplanted into Number 2 nursery containers. All black Number 2 nursery containers were spray painted with white paint. This was done to prevent the high summer temperatures of Paso Robles, California from overheating the black pots and affecting the roots. Two different media were prepared for Phase 1 of this project on the basis of their water holding capacities. 


\begin{tabular}{|c|c|c|c|c|c|}
\hline \multirow{2}{*}{$\begin{array}{c}\text { Scientific Name } \\
\text { Grasses }\end{array}$} & \multirow{2}{*}{$\begin{array}{c}\text { Common } \\
\text { Name } \\
\end{array}$} & \multicolumn{4}{|c|}{ Salt Tolerance } \\
\hline & & Sensitive & $\begin{array}{l}\text { Moderately } \\
\text { Sensitive }\end{array}$ & $\begin{array}{l}\text { Moderately } \\
\text { Tolerant }\end{array}$ & Tolerant \\
\hline Cynodon dactylon & Bermuda & & & & $\mathrm{X}^{1}$ \\
\hline Paspalum vaginatum & $\begin{array}{l}\text { Seashore } \\
\text { paspalum }\end{array}$ & & & & $\mathrm{X}^{1,2}$ \\
\hline Yucca spp. & Yucca & $X^{1}$ & & & $\mathrm{X}^{2}$ \\
\hline Buchloe spp. & Buffalo grass & & $\mathrm{X}^{1}$ & & \\
\hline \multicolumn{6}{|l|}{$\begin{array}{c}\text { Herbaceous } \\
\text { Perennials } \\
\end{array}$} \\
\hline $\begin{array}{l}\text { Osteospermum } \\
\text { fruticosum }\end{array}$ & $\begin{array}{l}\text { Trailing African } \\
\text { Daisies }\end{array}$ & $\mathrm{U}^{*}$ & & & \\
\hline Lantana camara & Lantana & & $\mathrm{X}^{1}$ & & \\
\hline Tagetes lemmonii & $\begin{array}{l}\text { Copper Canyon } \\
\text { Daisy }\end{array}$ & $\mathrm{U}^{*}$ & & & \\
\hline Fragaria chiloensis & Beach Strawberry & & & & $\mathrm{X}^{1}$ \\
\hline Lavandula angustifolia & Lavender & $\mathrm{U}^{*}$ & & & \\
\hline \multicolumn{6}{|l|}{ Shrubs } \\
\hline Myrica californica & Myrica & & $\mathrm{X}^{2}$ & & \\
\hline Cistus purpureus & Orchid Rockrose & $\mathrm{U}^{*}$ & & & \\
\hline $\begin{array}{l}\text { Trachelospermum } \\
\text { jasminoides }\end{array}$ & Star Jasmine & & $X^{1,2}$ & & \\
\hline Coprosma repens & Mirror Plant & & & & $\mathrm{X}^{2}$ \\
\hline Dodonea viscose & Purple Hop Bush & & $\mathrm{X}^{2}$ & & \\
\hline \multicolumn{6}{|l|}{ Annuals } \\
\hline Senecio cineraria & Dusty Miller & $\mathrm{U}^{*}$ & & & \\
\hline Pelargonium spp. & $\begin{array}{l}\text { Scented } \\
\text { Geraniums }\end{array}$ & & & $\mathrm{X}^{1}$ & \\
\hline $\begin{array}{l}\text { Begonia } \mathrm{x} \\
\text { semperflorens- } \\
\text { cultorum }\end{array}$ & Bedding Begonia & $\mathrm{X}^{1}$ & & & \\
\hline Gazania spp. & Gazania & & $\mathrm{X}^{1}$ & & $\mathrm{X}^{2}$ \\
\hline \multicolumn{6}{|c|}{$\begin{array}{l}\text { Tolerant- }\left(8-10 \mathrm{dSm}^{-1}\right) \text {, Moderately Tolerant }\left(6-8 \mathrm{dSm}^{-1}\right) \text {, Moderately Sensitive }\left(3-6 \mathrm{dSm}^{-1}\right) \text {, Sensitive }(<3 \\
\left.\mathrm{dSm}{ }^{-1}\right) \\
1 \text { - (Miyamoto et al., 2004), 2- (Costello et al., 2003) } \\
\mathbf{U}^{*}=\text { Undetermined }\end{array}$} \\
\hline
\end{tabular}

\section{Figure 10: Plant Species and Their Relative Salt Tolerance}

The first media prepared was $80 \%$ sand and $20 \%$ peat moss, a mixture containing mainly sand for sufficient drainage capability. The second prepared was $40 \%$ sand, $20 \%$ peat moss, and $20 \%$ perlite, a mixture containing perlite to promote aeration in 
the media. Ten plants of each species were transplanted from their nursery containers into number 2 spray painted nursery containers. Five plants of each species were planted in the $80 \%$ sand and $20 \%$ peat moss media and five in the $40 \%$ sand, $40 \%$ peat moss, and $20 \%$ perlite media. A total of 90 plants were planted in each media for a total of 180 plants for the first phase of this experiment.

Sunshine is the manufacturer of the Peat Moss used for the media in this experiment and it provides $7 \mathrm{ft}^{3}$, or $0.26 \mathrm{yd}^{3}$, of peat moss per bag. The $80 \%$ sand and $20 \%$ peat moss media requires that approximately half of one full bag of peat moss be used for the 90 pots of this mixture. Horti-Perl is the manufacturer of the perlite used for the $40 \%$ sand, $40 \%$ peat moss, and $20 \%$ perlite media and provides $5 \mathrm{ft}^{3}$, or $0.18 \mathrm{yd}^{3}$ of perlite. Approximately one full bag (.97 bags) of Sunshine peat moss was used in the 90 pots for this media, and approximately three quarters of one bag ( $0.68 \mathrm{bags})$ of perlite.

After potting, all plant material was irrigated with potable irrigation water at California Polytechnic State University, San Luis Obispo Horticulture Unit for a period of 9 days starting on Aug. 7, 2008 and ending on August 16, 2008 for proper root establishment. Once established, all plants were transported to the experimental site at the Paso Robles Waste Water Treatment Plant.

A drip irrigation system was installed to provide sufficient distribution of recycled water to the plants. Plants were placed in four sections divided by class 200 PVC pipe irrigation lines and half inch drip tubing line. PVC 3/4" manifolds were assembled according to the location of the drip line between the Number 2 nursery plant pots. Each row of plants was divided by the $3 / 4$ "drip tubing. Next, 180 black spaghetti drip emitters were punched into the $3 / 4$ " black tubing and placed into the media that is in each 
individual number 2 container. Figure 11 shows the layout design for the first phase of the project. The irrigation clock was provided by the Paso Robles Waste Water Treatment Plant, which allowed a controlled irrigation schedule.

The irrigation schedule for all plants was Monday through Saturday, for 10 minutes a day, at $9 \mathrm{am}$. An increase in water pressure after the first month of irrigation caused a change in watering schedule, from 10 minutes a day to 7 minutes a day, to prevent water stress to plants. This change took place on September 29, 2008, 44 days into the project. 
Plant Layout Phase \#1

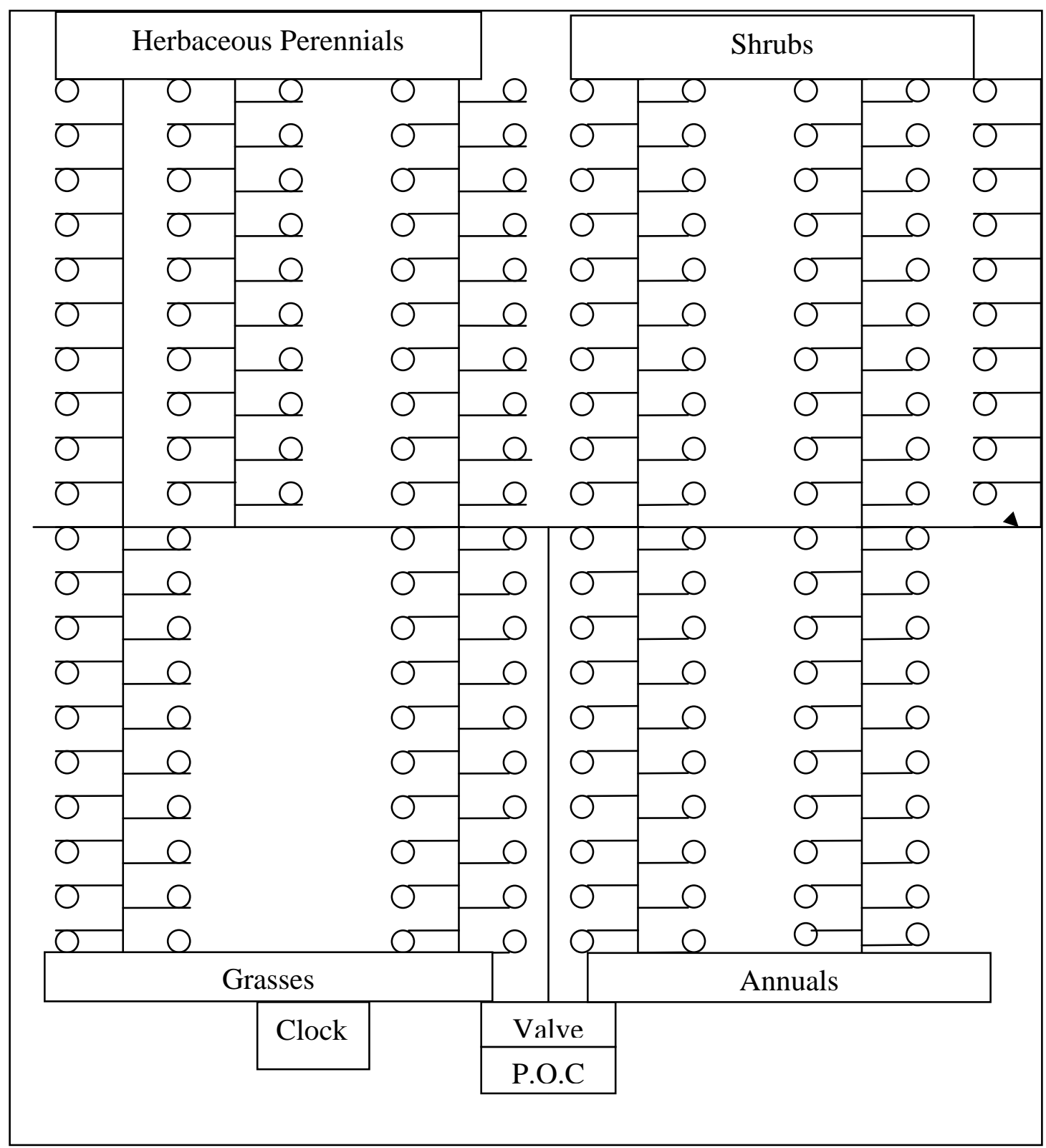

Figure 11

Observations were taken weekly to assess the visual aesthetics of the plants in response to the reclaimed water. A score was given to each plant which represent the 5 plant samples in each media for a total of two scores per species. Plants were scored 
based on the overall health of the plant, leaf color, growth from previous weeks, and visible salt damage on leaves/flowers. Plants were scored on a scale from 1 (dead) to 5 (perfect) according to aesthetic judgment from week to week. Table 6 below is a representation of aesthetic scoring with pictures that were taken with a high resolution digital camera to capture and match scoring with visual aesthetics.

\section{Table 6: Plant Quality Scoring Criteria}

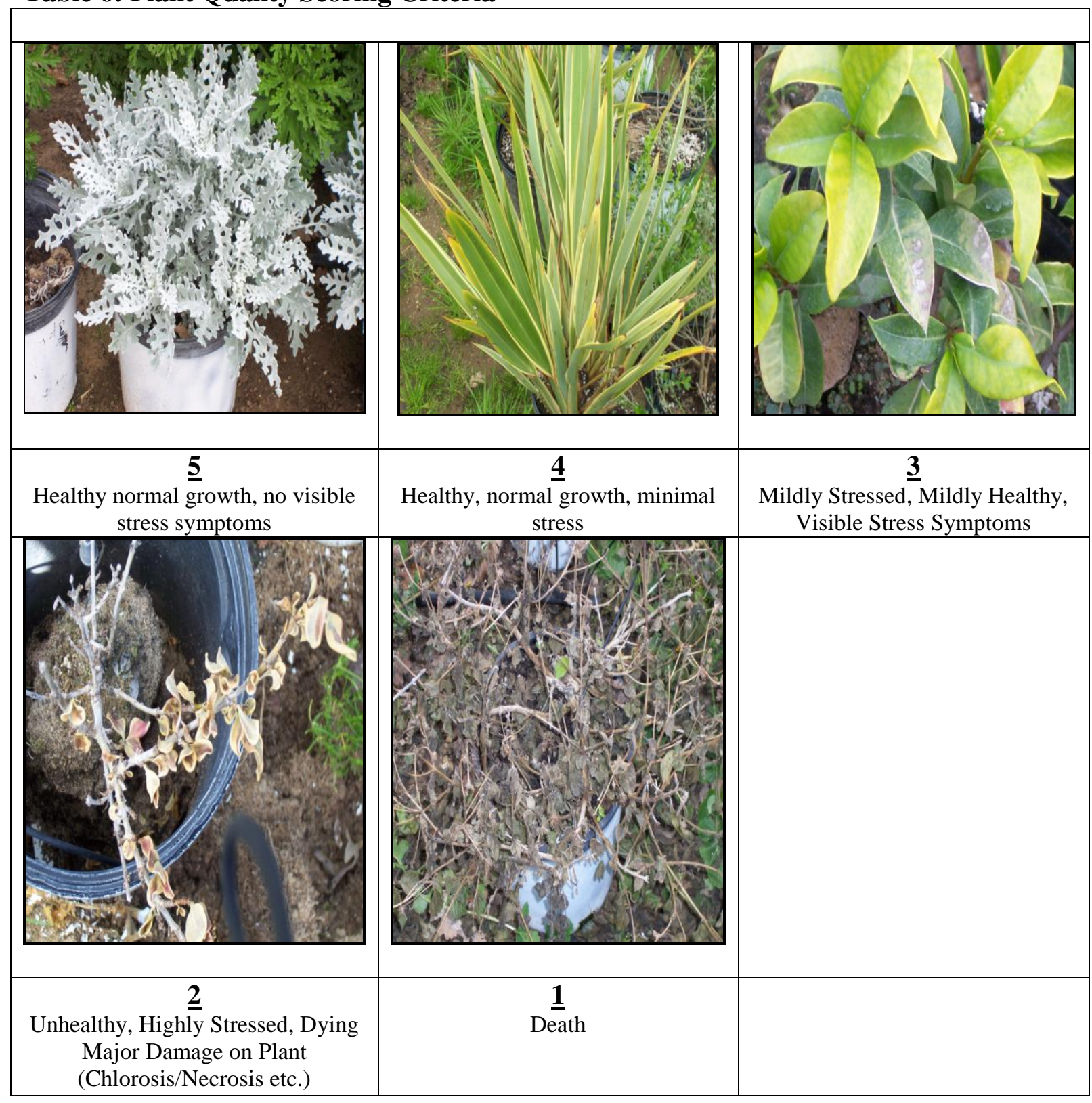


Media samples were taken at the beginning (Week 4) and end (Week 12) of the project to gain an understanding of the chemistry of the media after reclaimed water was used for irrigation. Two samples were taken for each species, one per media and two plant species with the same media were combined for funding purpose (Table 7). Soil was extracted from each of the 5 pots in each media, placed in a zip-lock sandwich bag, and marked according to the treatment. Water was collected from the irrigation system and put into a plastic bottle each time media samples were taken. The media and water samples were then sent to Fruit Growers Lab located in Santa Paula, California for analysis of sodium, chloride, $\mathrm{pH}, \mathrm{EC}$, and total dissolved salts (TDS).

\section{Table 7: Plant Species Media Combined for Analysis}

\begin{tabular}{|l|l|}
\hline \multicolumn{2}{|c|}{ Plants } \\
\hline Cynodon dactylon & Paspalum vaginatum \\
\hline Yucca spp. & Buchloe spp. \\
\hline Osteospermum fruticosum & Lantana camara \\
\hline Tagetes lemmonii & Fragaria chiloensis \\
\hline Lavandula angustifolia & Myrica californica \\
\hline Cistus purpureus & Trachelospermum jasminoides \\
\hline Coprosma repens & Dodonea viscose \\
\hline Senecio cineraria & Pelargonium spp. \\
\hline Begonia spp. & Gazania spp. \\
\hline
\end{tabular}

The final step of phase I was to perform a statistical analysis from the aesthetic score data received from the first 12 weeks of the project, on the 18 species of plants in 2 different media types. This analysis was a multivariate approach to investigating repeated data with minimal assumptions of results. Variables that were measured and compared were the effect of media and time on aesthetic score, the effect of time on aesthetic score, and the effect of soil on aesthetic score. 


\section{Phase 2-Winter}

The second phase of this project was conducted at the same location as Phase I, the Paso Robles Waste Water Treatment Plant (PRWWTP). Material used for the second phase II is listed in Appendix 3. Reclaimed irrigation water from the same source was used and the irrigation setup from Phase I was modified to accommodate the new plants. Phase I plants were also observed and scored again on a monthly basis to determine the long term effects of the reclaimed water. Phase II plants were observed and scored on a weekly basis for short term effects of the reclaimed water.

Plants for phase II were selected using the same criteria as Phase I, on the basis of their tolerance (sensitive, moderately sensitive, moderately tolerant, or tolerant) to salt in irrigation water and media, their popularity in landscapes throughout the Central Coast region of California, and their tolerance to conditions characteristic of the growing season (i.e., frost tolerant, winter flowering, etc.). Turfgrasses were not used in Phase II as groundcovers were substituted. Table 11 lists the plants that were selected for phase II and their relative tolerance to salt. All plants were purchased in Number 1 nursery containers, with exception of Hedera helix and Gazania spp., which were bought in flats and transplanted into the Number 2 nursery containers. 
Table 8: Plant Species and Their Relative Salt Tolerance

\begin{tabular}{|c|c|c|c|c|c|}
\hline Scientific Name & Common Name & \multicolumn{4}{|c|}{ Salt Tolerance } \\
\hline Shrubs & & Sensitive & $\begin{array}{l}\text { Moderately } \\
\text { Sensitive }\end{array}$ & $\begin{array}{l}\text { Moderately } \\
\text { Tolerant }\end{array}$ & Tolerant \\
\hline $\begin{array}{l}\text { Nandina } \\
\text { domestica }\end{array}$ & Heavenly bamboo & $X^{1,2}$ & & & \\
\hline Photinia fraseri & Red Tip photinia & $\mathrm{X}^{1,2}$ & & & \\
\hline Ilex cornuta & Chinese holly & $\mathrm{X}^{1,2}$ & & & $\mathrm{X}^{2}$ \\
\hline Eleagnus pungens & Silverberry & & $\mathrm{X}^{1,2}$ & & \\
\hline Baccharis pilularis & Coyotebush & & & $X^{1}$ & $X^{2}$ \\
\hline $\begin{array}{l}\text { Ceanothus } \\
\text { thyrsiflorus }\end{array}$ & California lilac & $\mathrm{U}^{*}$ & & & \\
\hline Thuja orientalis & Oriental arborvitae & & $X^{1,2}$ & & \\
\hline Nerium oleander & Oleander & & & $\mathrm{X}^{1}$ & $X^{2}$ \\
\hline \multicolumn{6}{|l|}{ Perennials } \\
\hline $\begin{array}{l}\text { Agapanthus } \\
\text { africanus }\end{array}$ & Lily of the Nile & $X^{1}$ & $X^{2}$ & & \\
\hline Lonicera japonica & Japanese honeysuckle & $\mathrm{X}^{1}$ & & & $\mathrm{X}^{2}$ \\
\hline Phormium tenax & New Zealand flax & $\mathrm{U}^{*}$ & & & \\
\hline $\begin{array}{l}\text { Pennisetum } \\
\text { setaceum }\end{array}$ & Purple fountain grass & & & $X^{1}$ & \\
\hline \multicolumn{6}{|l|}{. Groundcovers } \\
\hline Heuchera spp. & Coral Bells & $\mathrm{U}^{*}$ & & & \\
\hline $\begin{array}{l}\text { Rosmarinus } \\
\text { officinalis }\end{array}$ & Rosemary & & $X^{1}$ & & $X^{2}$ \\
\hline Vinca major & Vinca & $\mathrm{X}^{1}$ & & & $X^{2}$ \\
\hline Hedera helix & English ivy & $\mathrm{X}^{1}$ & & & $\mathrm{X}^{2}$ \\
\hline Gazania spp. & Gazania & & $X^{1}$ & & $\mathrm{X}^{2}$ \\
\hline Ceanothus griseus & Common creeper & $\mathrm{U}^{*}$ & & & \\
\hline \multicolumn{6}{|l|}{ Annuals } \\
\hline $\begin{array}{l}\text { Antirrhinum } \\
\text { majus }\end{array}$ & Snapdragon & $\mathrm{U}^{*}$ & & & \\
\hline Primula spp. & Primrose & $\mathrm{U}^{*}$ & & & \\
\hline Viola spp. & Pansy & $\mathrm{U}^{*}$ & & & \\
\hline $\begin{array}{l}\text { Calendula } \\
\text { officinalis }\end{array}$ & Calendula & $\mathrm{U}^{*}$ & & & \\
\hline \multicolumn{6}{|c|}{$\begin{array}{l}\text { Tolerant- }\left(8-10 \mathrm{dSm}^{-1}\right) \text {, Moderately Tolerant }\left(6-8 \mathrm{dSm}^{-1}\right), \text { Moderately Sensitive }\left(3-6 \mathrm{dSm}^{-1}\right), \text { Sensitive }(<3 \\
\left.\mathrm{dSm}{ }^{-1}\right) \\
1 \text { - (Miyamoto et al. 2004), 2- (Costello et al. 2003) } \\
\mathbf{U}^{*}=\text { Undetermined }\end{array}$} \\
\hline
\end{tabular}


The first step for Phase 2 of the project was to collect 180 Number 2 nursery containers. Spray paint was not needed for the black containers used in this phase of the project, which took place in the winter months, due to the absence of harsh, extreme, high light. After realizing that the $80 \%$ Sand and $20 \%$ Peat Moss media used in Phase I leached out of a majority of the pots, it was decided that the $40 \%$ Sand, $40 \%$ Peat Moss, and $20 \%$ Perlite media would be more effective for the second phase of the project in all containers. This media has better structure, water holding capacity, and did not leach out of the holes in the bottom of the pots.

The same Sunshine Peat Moss used in phase I was used for phase II of experimentation. As determined earlier, one bag of the Sunshine Peat Moss makes $7 \mathrm{ft}^{3}$, or $0.26 \mathrm{yd}^{3}$ of soil. Horti-perl was used for this phase of the project, and it made $5 \mathrm{ft}^{3}$ or $0.18 \mathrm{yd}^{3}$ of perlite. The amount of bags of peat moss needed in the pots for this phase of the project was approximately two bags (1.9 bags) and the number of bags of perlite used is approximately one and a half bags (1.4 bags). The redwood boxes required approximately two bags (2.06 bags) of Peat Moss and approximately one bag (1.03 bags) of Perlite.

All plant material was planted and irrigated with potable irrigation water at Miranda Ranch in Nipomo, California for a period of 17 days starting on December 26, 2008 and ending on January 12, 2009 for proper root establishment. Once established, all plants were transported to the experimental site at the Paso Robles Waste Water Treatment Plant.

Next step the irrigation system was modified to add an additional 180 pots to the previous layout from Phase I. The only modification to this system was an addition to 
the ends of both lateral lines, with additional drip irrigation tubes connected and the addition of a lateral line to transport water to the redwood boxes. Drip tube was installed down each row of plants and spaghetti drip emitters were connected to the drip line and placed in each plant pot. Figure 12 illustrates the alterations made to the irrigation system in phase II. The same irrigation schedule used in Phase I was used in Phase II. This schedule was 6 days a week, Monday through Saturday, for 7 minutes a day.

All plants were scored by the same criteria as in phase I, by overall health of the plant, leaf color, growth from previous weeks, and visible salt damage on leaves/flowers. A score was given for each set of plants from 1 to 5 and criteria for scoring is illustrated previously in Table 6. 


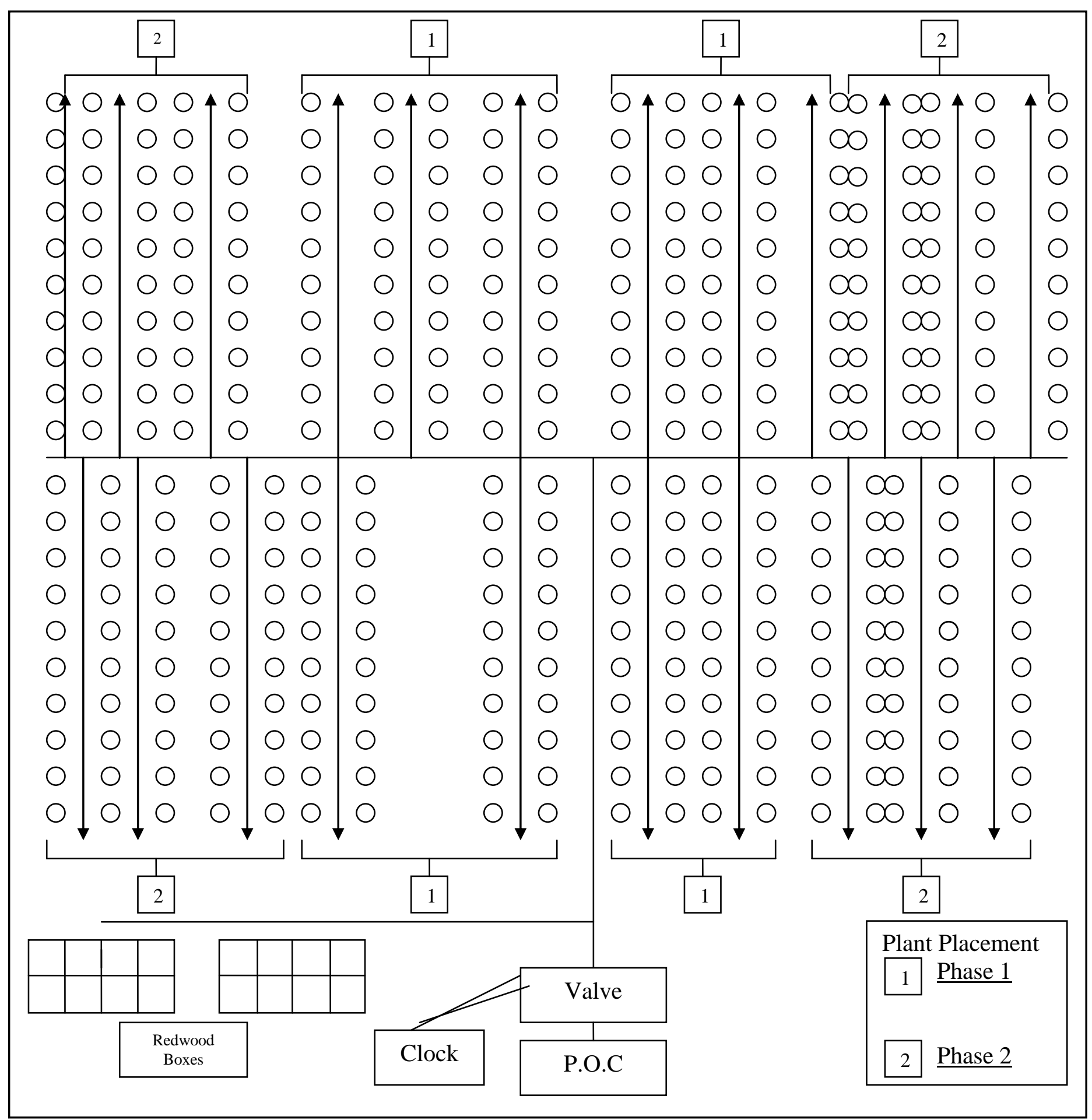

Figure 12: Phase I and Phase II Plant Layout 


\section{$\underline{\text { Results }}$}

\section{Quality Results Phase I}

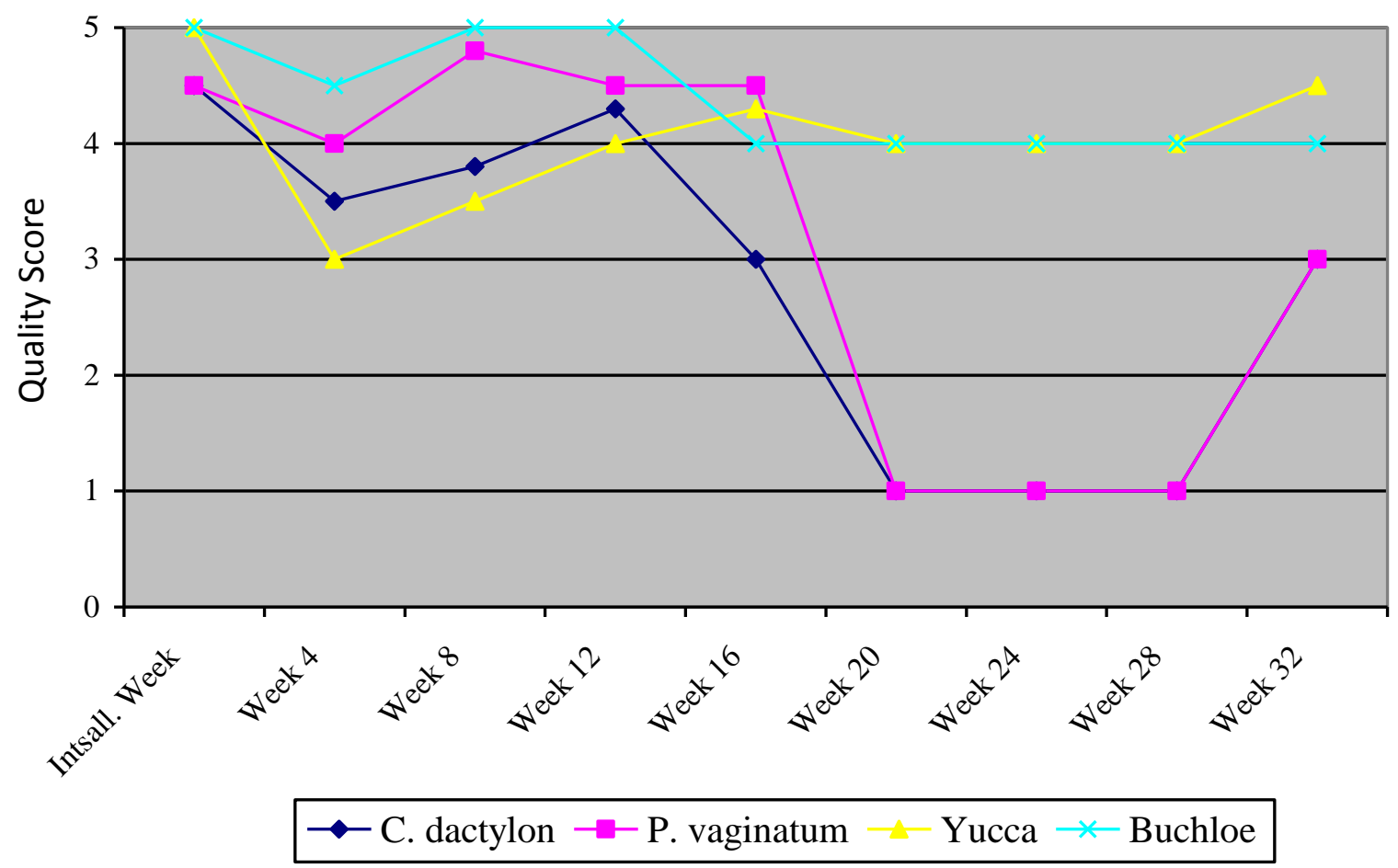

Figure 13: Quality Results for Grasses Planted in 80\% Sand, $20 \%$ Peat Moss Media (Installation week August 28, 2008- Week 32 April 6, 2009)

Grasses that were planted in $80 \%$ sand and $20 \%$ peat moss exhibited quality scores above 4.0, meaning that at the beginning of the experiment plants were healthy, with minimal (less than 10\%) to no stress. All of the grasses for the first 12 weeks (categorized as Phase I of the project) remained above the satisfactory level of quality scoring ( 3.0 being the minimum acceptable score). Yucca spp. at week 4.0 had an aesthetic score of 3 due to the lack of growth, discoloration on leaves, as well as tip necrosis. From week 4 to week 16, however, Yucca spp. increased in health and growth eventually leveling off to a consistent score of 4.0 throughout most of the project with minimal stress from tip necrosis. 


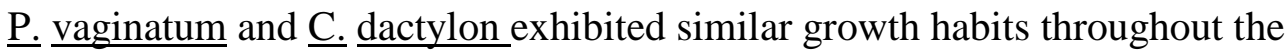
project with consistent growth until week 16 where $\underline{P}$. vaginatum dropped from quality score 4.5 to 1.0 and $\underline{\mathrm{C}}$. dactylon from 3.0 to 1.0 by week 20 . Both grasses sustained this score until the final 4 weeks of the project where scores increased to 3.0. Buchloe spp. sustained quality scores of 4.0 or better throughout the entire 32 weeks of the project.

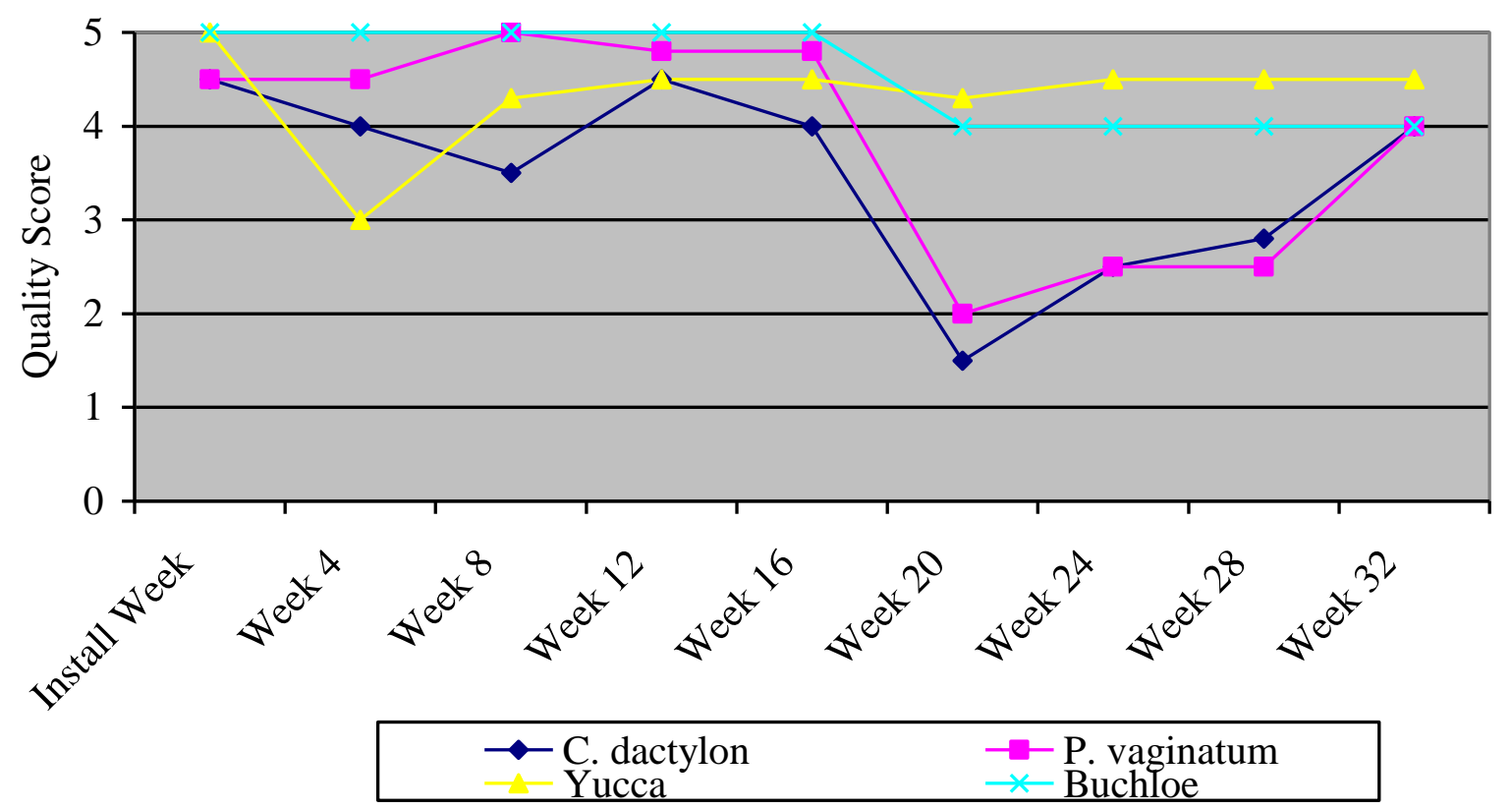

Figure 14: Quality Results for Grasses Planted in $40 \%$ Sand, 40\% Peat Moss, and 20\% Perlite Media

Grasses planted in $40 \%$ sand, $40 \%$ peat moss, and $20 \%$ perlite was all healthy with quality scores $\geq 4.5$ Yucca spp. at week 4 showed a decrease from 5.0 at installation to 3.0. From week 4 to week 32 Yucca spp. increased above 4.0 and sustained quality scores of 4.3 or above due to consistent growth with minimal stress (tip necrosis). In this media, $\underline{P}$ vaginatum and $\underline{\mathrm{C}} . \underline{\text { dactylon }}$ showed similar growing habits as in the other media in that between week 16 and week 20 grasses declined in quality from 4.8 to 2.0 and 4.0 
to 1.5 , respectively. $\underline{\text { P. vaginatum }}$ had some major dieback with orangish discoloration on leaves and $\underline{\mathrm{C}}$. dactylon showed a majority of leaves $(\geq 50 \%)$ with necrotic, yellow discoloration. Buchloe spp. consistently remained $\geq 4.0$ throughout the duration of experimentation.

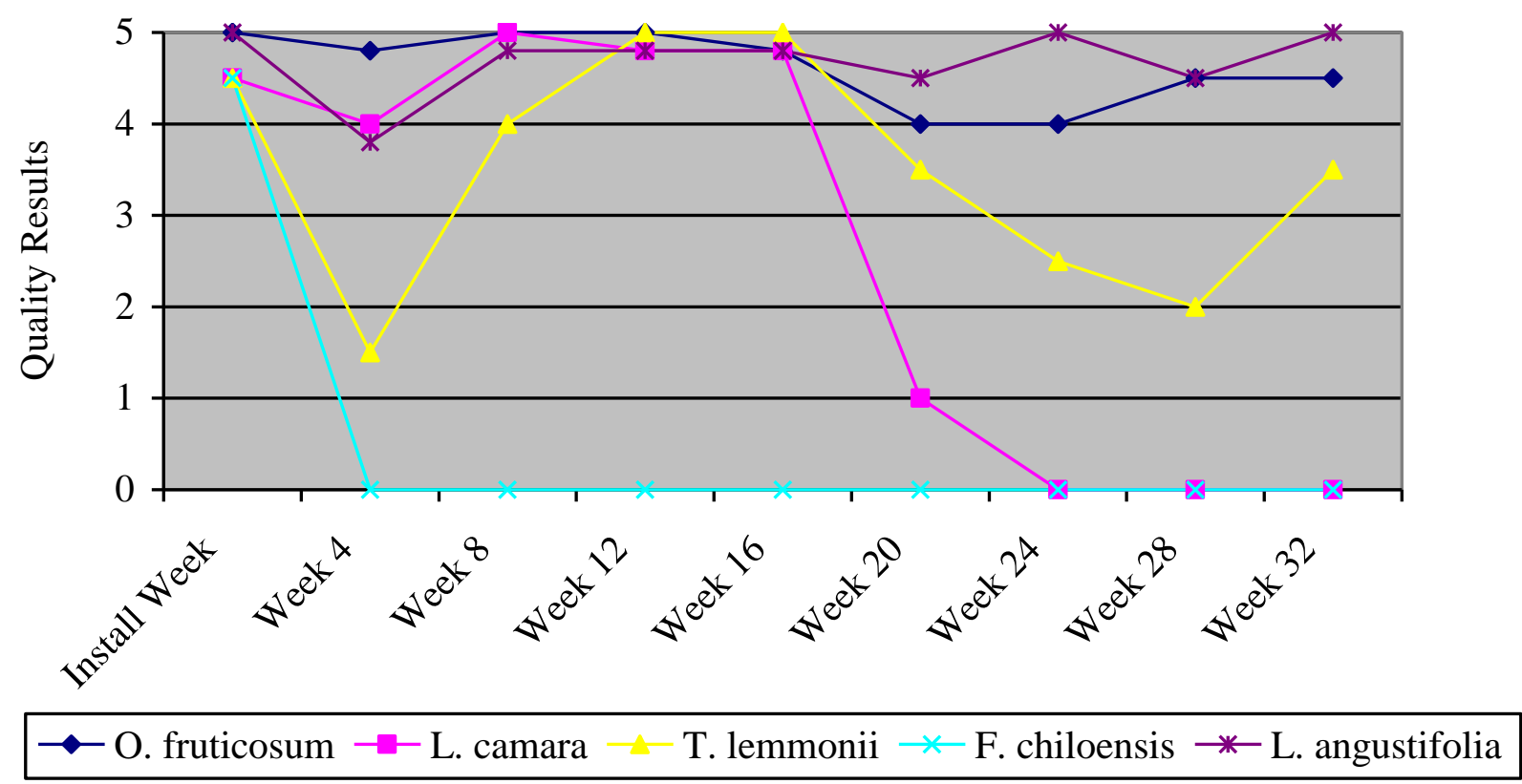

Figure 15: Quality Results for Herbaceous Perennials Planted in 80\% Sand and $20 \%$ Peat Moss

F. chiloensis declined immediately in aesthetic appearance in $80 \%$ sand and $20 \%$ peat moss after installation, where it started at 4.5. By week 4, quality score of all samples was 0 . Necrosis on entire plant was evident and soil structure was poor. $\underline{\text { L. }}$ camara for the first 16 weeks was healthy with quality scores ranging from 4.0 to 5.0. At

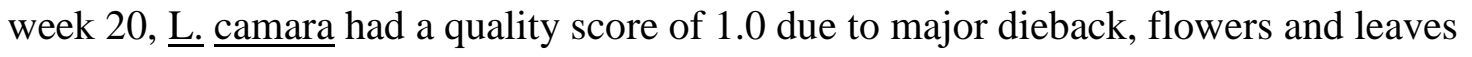


necrotic on almost all of the plant (approximately 90\%). By week 24, all samples planted in this media were dead and given a quality score of 0 . Tagetes lemmonii had inconsistent growth patterns with quality score of 4.5 at installation, and then dropped in quality to 1.5 in this media at week 4 because of necrotic leaves and flowers on more than $50 \%$ of plant, with only green at base of plant, and some leaf abscission. The score increased from 1.5 to 5.0 from week 4 to week 16 with lots of new green growth, flowers

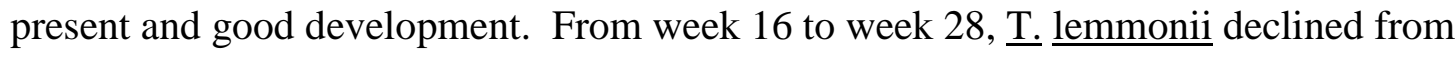
5.0 to 2.0 and then increased over the final 4 weeks with an aesthetic score of 3.0 at week 32. Osteospermum fruticosum and $\underline{\mathrm{L}}$. angustifolia exhibited the most consistent quality scores over the 32 weeks with scores not dropping below 3.8 and scores as high as 5.0. These herbaceous perennials had consistent green growth, minimal damage to plants (less than $10 \%$ ) on both species, and healthy development over the 32 week period. 


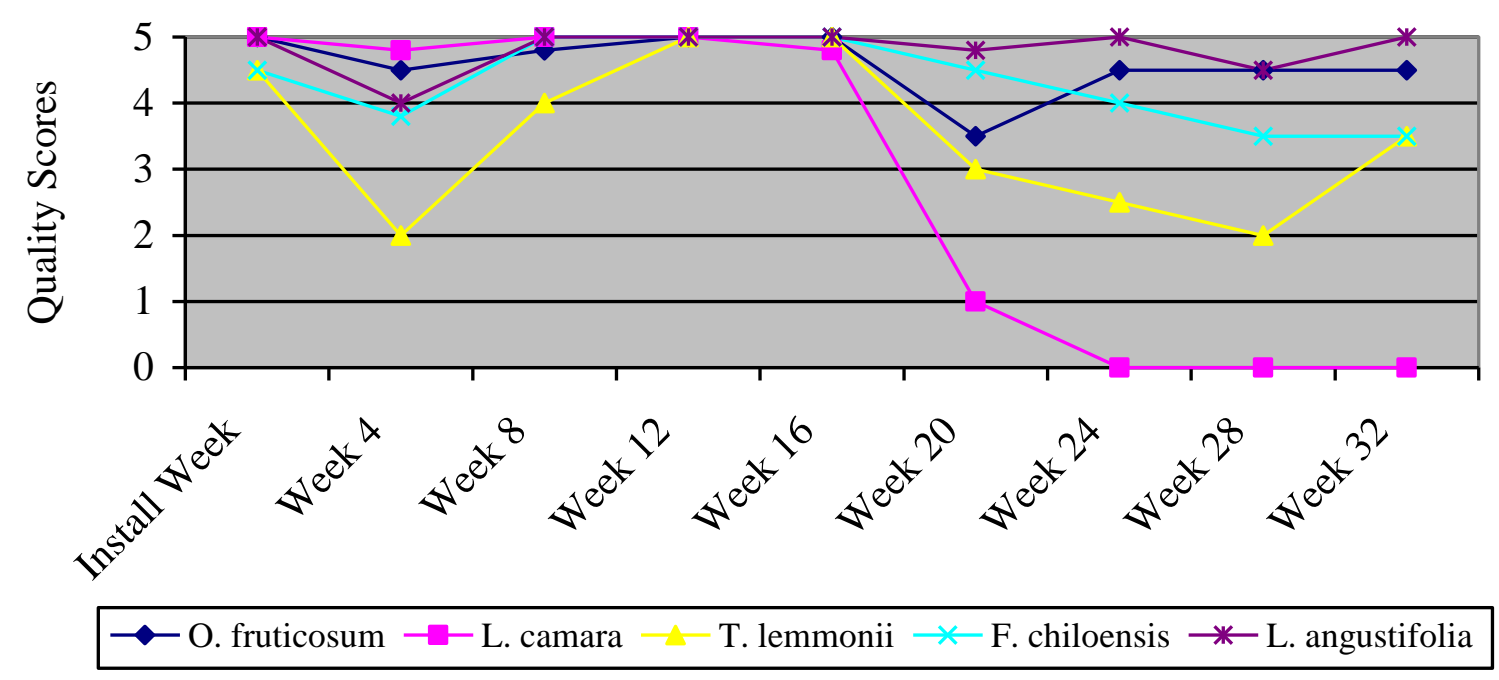

Figure 16: Quality Results for Herbaceous Perennials Planted in 40\% Sand, 40\% Peat Moss, and 20\% Perlite Media

L. camara is the only herbaceous perennial in $40 \%$ sand, $40 \%$ peat moss, and $20 \%$ perlite media to die during the duration of this project. Consistent growth occurred from installation to week 16 and quality scores never dropped below 4.8 during this period. After week 16, plants declined to1.0 score in week 20 and to 0 by week 24 . Leaves during this period were necrotic and eventually abscissed from plant canopy. Tagetes lemmonii was inconsistent in its growth habit over the duration of the experiment with identical scores as other samples grown in $80 \%$ sand and $20 \%$ peat moss media. Scores ranged from 4.5 at installation to 2.0 at week 4 , then back up to 5.0 at weeks 12 and 16 . At week 28 the quality score was 2.0 , before finishing the project with a quality score of 3.5. Osteospermum fruticosum, $\underline{\mathrm{L}}$ angustifolia, and F. chiloensis all remained above quality score of 3.5 with good development, healthy green growth, and minimal damage

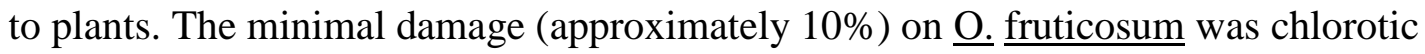
mottling and necrosis, while $\underline{\underline{L}}$ angustifolia had marginal chlorosis on a few lower, older 
leaves. F. chiloensis had chlorotic discoloration, red and bronze in color, and marginal necrosis on approximately $10 \%$ of the leaves.

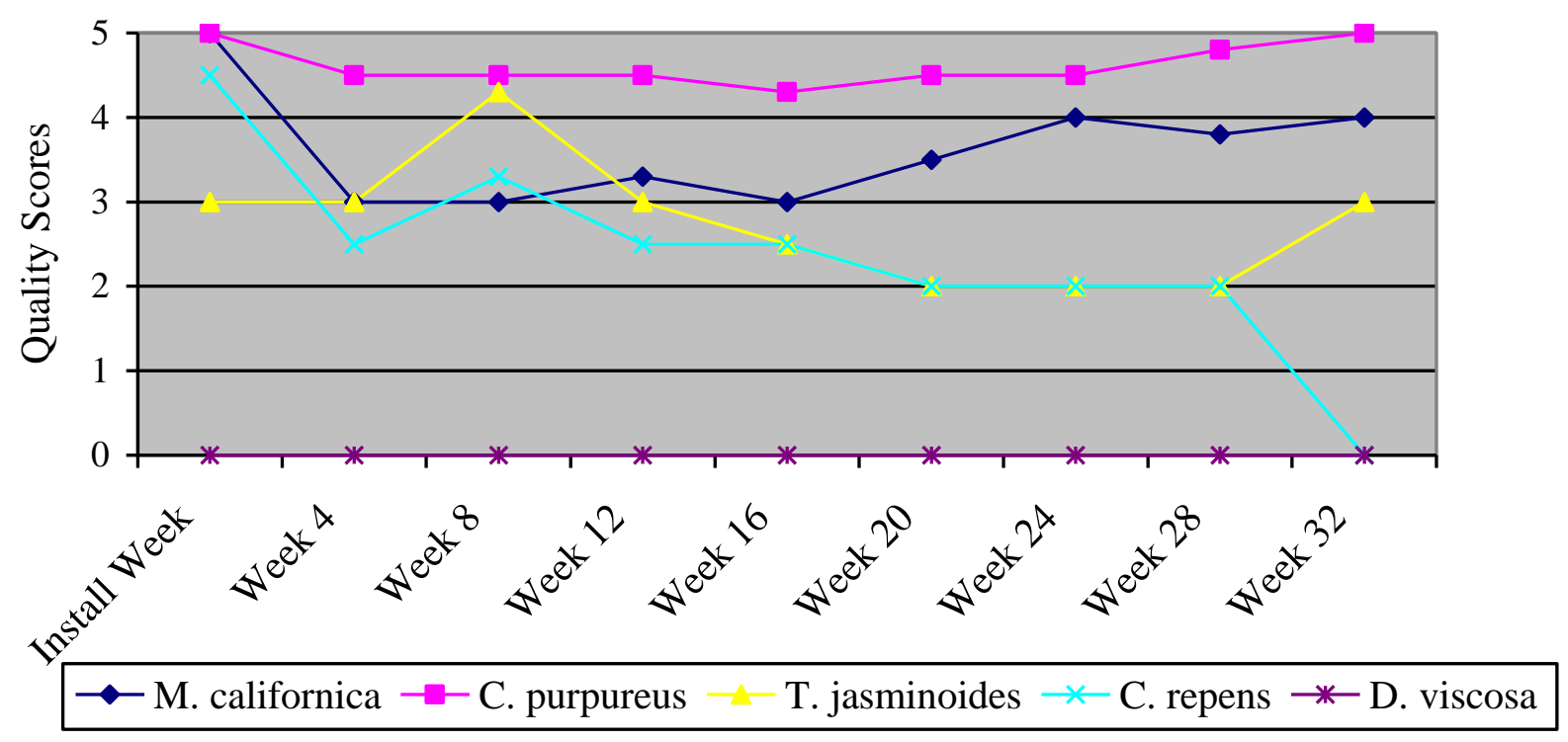

Figure 17: Quality Results for Shrubs Planted in 80\% Sand and 20\% Peat Moss Media

No results were recorded for D. viscosa due to theft of all samples in $80 \%$ sand/ $20 \%$ peat moss. Trachelospermum jasminoides had a beginning quality score of 3.0 and over the first 8 weeks increased in quality to its highest score of 4.3. During this time minimal chlorosis was present on leaves with new growth present and leaves were green throughout most of the plants. From week 8 to week 28 plants went from 4.3 score to 2.0 with a steady decline. Plants during this period of time exhibited major interveinal, mottled and irregular chlorosis, white discoloration on leaves, necrotic margins on some leaves, yellow and reddish discoloration of leaves. Trachelospermum jasminoides' week 


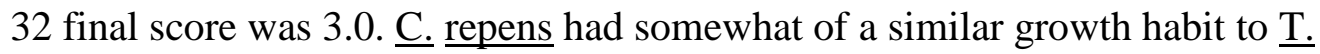
jasminoides in that from installation to week 32 there was a clear decline in quality scoring. The difference in the two species, however, was observed in week 32 where $\underline{\mathrm{C}}$. repens plants were $100 \%$ necrotic and leaves were beginning to abscise.

Myrica californica remained above satisfactory levels at the beginning of the experiment with a score of 5.0 and never dropped below a score of 4.0. Scores dropped to 3.0 because plants had bronzing on leaves, tip burn, marginal necrosis, and flecking on leaves. Cistus purpureus remained healthy throughout the project with a high score of 5.0 and a low score of only 4.3. Cistus purpureus remained green from week to week, with minimal to no damage, showing healthy new growth each week.

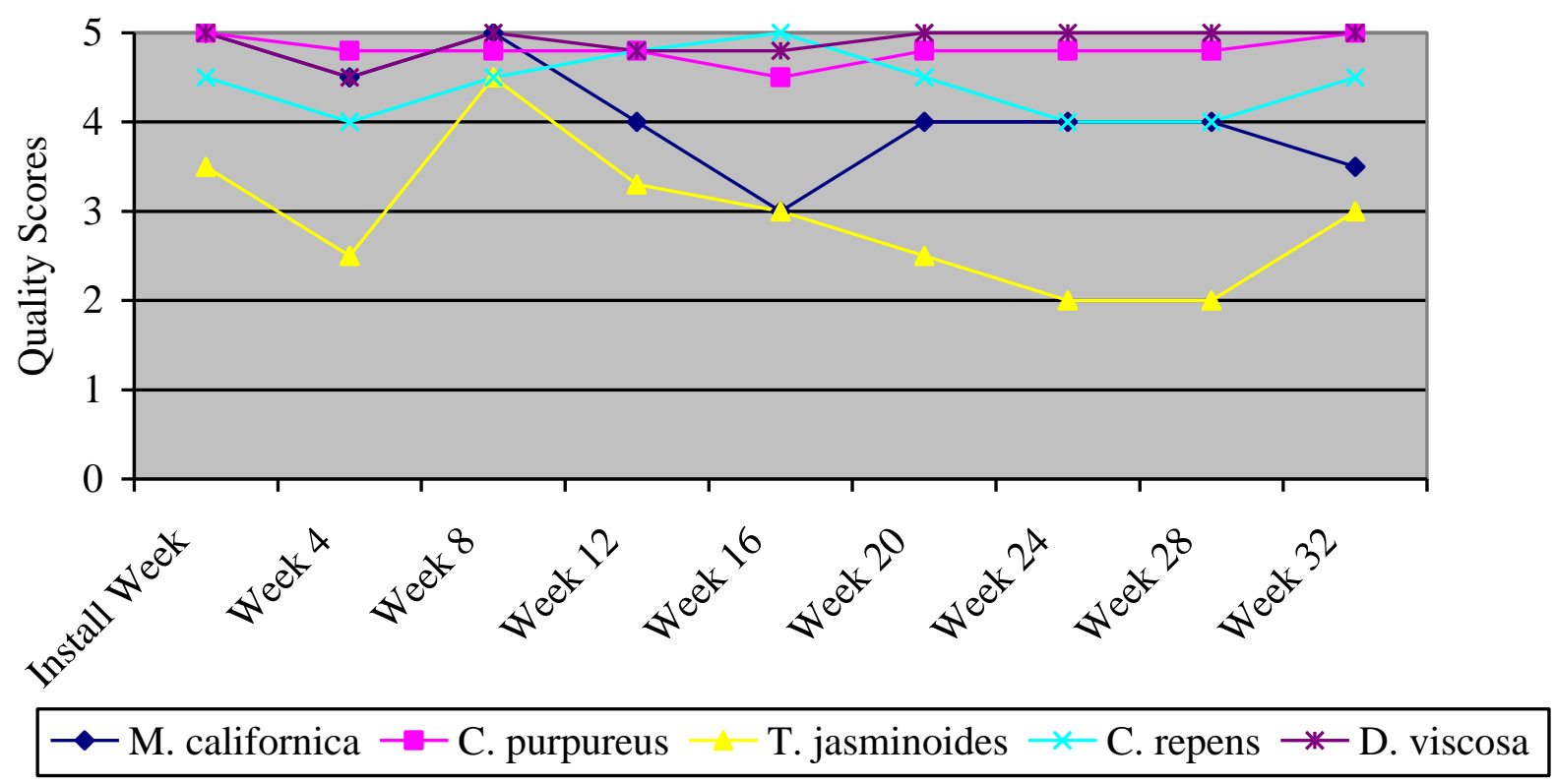

Figure 18: Quality Results for Shrubs Planted in $\mathbf{4 0 \%}$ Sand, $40 \%$ Peat Moss, and 20\% Perlite Media 
Trachelospermum jasminoides planted in $40 \%$ sand, $40 \%$ peat moss, and $20 \%$ perlite media was slightly stressed with some interveinal chlorosis, bronze mottled chlorosis and therefore received a quality score of 3.5 to start the project. Differential growth patterns for this species in this media were evident when at week 4 the quality score dropped to 2.5 due to more severe stress. At week $8 \underline{\mathrm{T}}$. jasminoides scored a 4.5 because of lots of new growth with no new chlorosis, new flowers and buds present and healthy normal development present. From week 8 to week 28 scores gradually declined to 2.0 due to continual chlorosis on more than $50 \%$ of the leaves, reddish/bronze mottling on some leaves, marginal necrosis, leaf abscission and stunted growth. Trachelospermum jasminoides finished with a 3.0 quality score in this media. Myrica californica, $\underline{\text { C. }}$

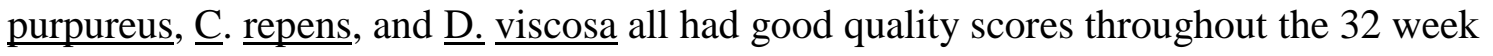
experiment and $\underline{\mathrm{M}}$ californica was the only shrub to drop below an aesthetic score of 4.0. Myrica californica still managed to score in the satisfactory range $(\geq 3)$ throughout the entire project, with scores as high as 5.0 in week 8 and a majority of the experiment above the range of 4.0. The score of 3.0 in week 16 was given because of yellow discoloration on leaves, necrotic flecking, and leaf curl on just below $25 \%$ of the plant.

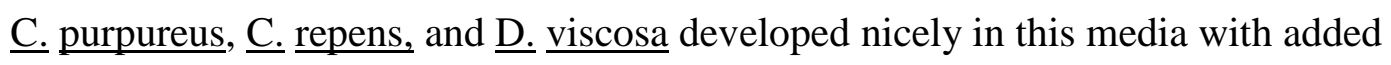
recycled water. Plants were healthy with natural plant coloration, lots of new growth from previous weeks and minimal $(\leq 10 \%$ of plant) to no damage on plants. 


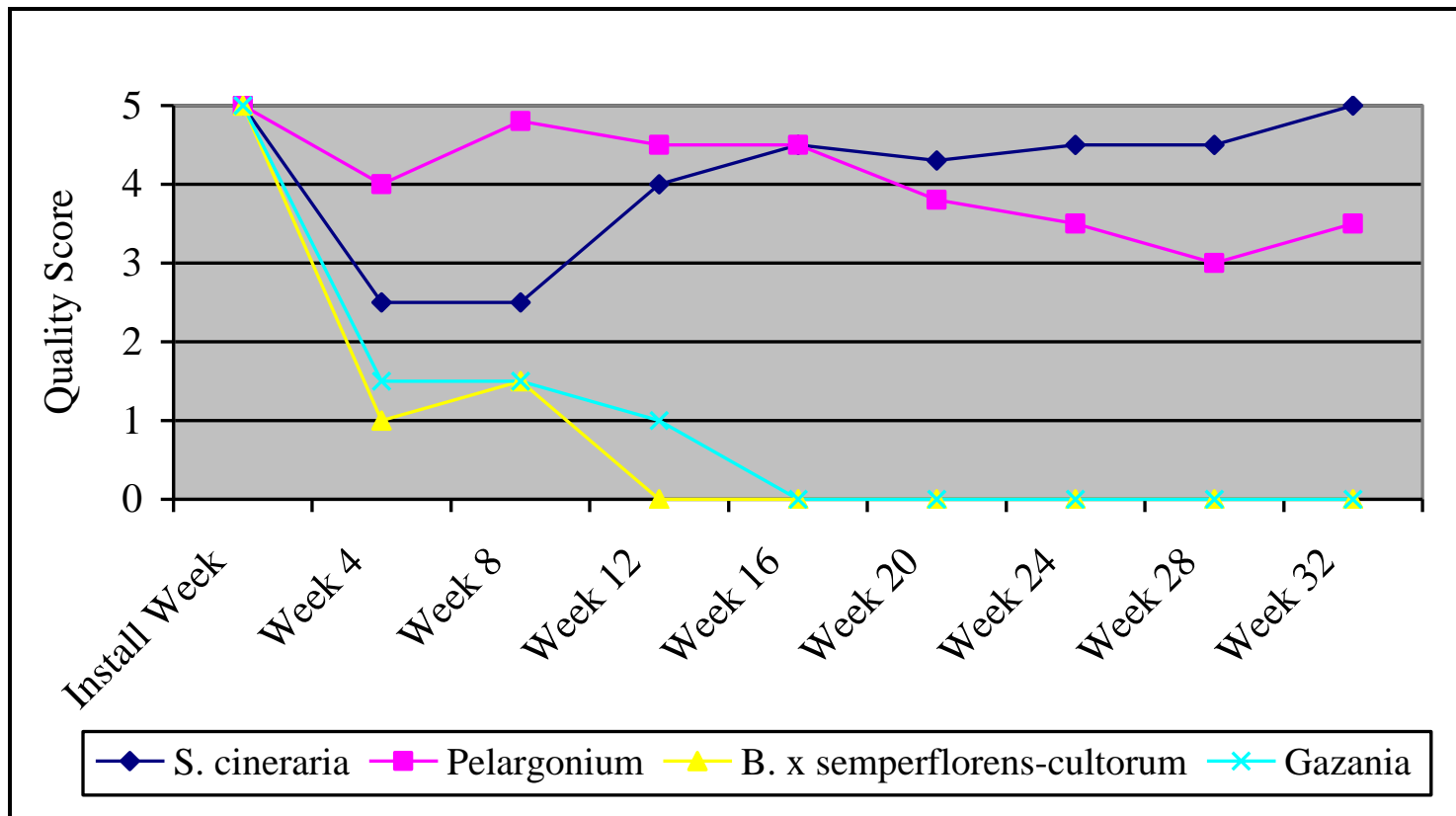

Figure 19: Quality Results for Annuals Planted in 80\% Sand and 20\% Peat Moss Media

Gazania spp. had no relevant data to measure in this experiment due to animal

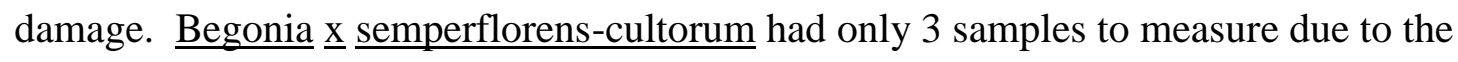
theft of two samples. An immediate decline in quality appearance was obvious from week to week until death occurred on week 12 . Plants had only stems with necrotic

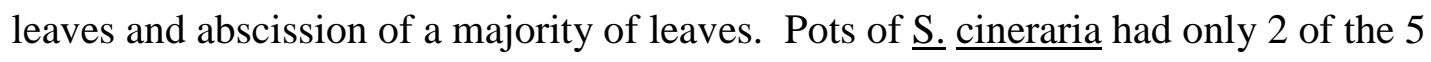
samples contain enough of the $80 \%$ sand and $20 \%$ peat moss for plant growth. Both of the remaining samples were very healthy showing consistent new growth and minimal damage to plants. Scores started at 5.0 for this species then dropped below satisfactory scores with a 2.5 aesthetic score on week 8 and week 12 due to leaf wilting, thin canopies, and stunted growth. The following weeks (16-32) plants increased quality appearance and rose from 2.5 at week 16 to 5.0 at week 32. Pelargonium spp. was the only consistent growing annual of the four species tested. Scores remained above the 
satisfactory level of 3.0 throughout the entire project, only decreasing because of necrotic leaves and some interveinal chlorosis on less than $25 \%$ of the leaves of the plants.

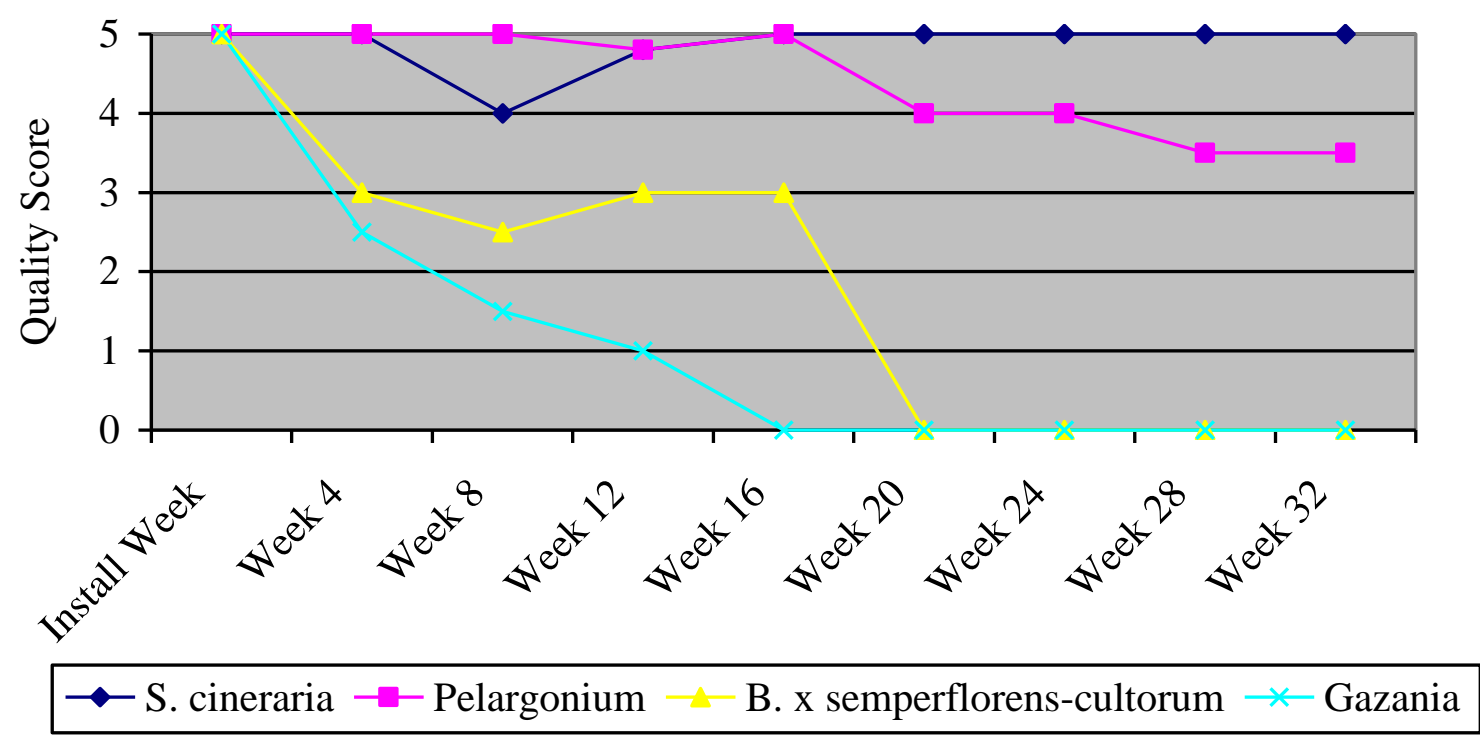

Figure 20: Quality Results for Annuals Planted in 40\% Sand, 40\% Peat Moss, and 20\% Perlite Media

Gazania spp. planted in $40 \%$ sand/ $40 \%$ peat moss/ $20 \%$ perlite, like the other media, had insignificant results due to animal damage to all samples. Scores were given based on the base of the plant that was left after animal damage. Therefore these results are not accurate.

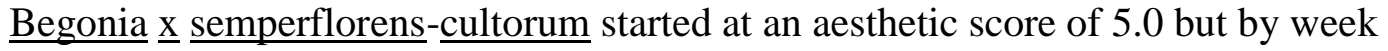
4 had decreased to 3.0. At week 8 samples decreased in appearance and received a score of 2.5, just under the satisfactory limit. Week 12 and 16 had equal scores of 3.0 before the plants died. Pelargonium spp. decreased in aesthetic appearance throughout the weeks due to some necrotic margins on upper leaves, as well as some interveinal 
chlorosis but never dropped below 3.5. In this media plants developed from week to week with green, abundant growth, and minimal damage (under 25\%). Senecio cineraria had scores above 4.0 through the 32 weeks and maintain a quality score of 5.0 for a majority of the experiment. Samples had growth throughout the experiment, with healthy normal development, and no visible damage on plants.

\section{Quality Results Phase II}

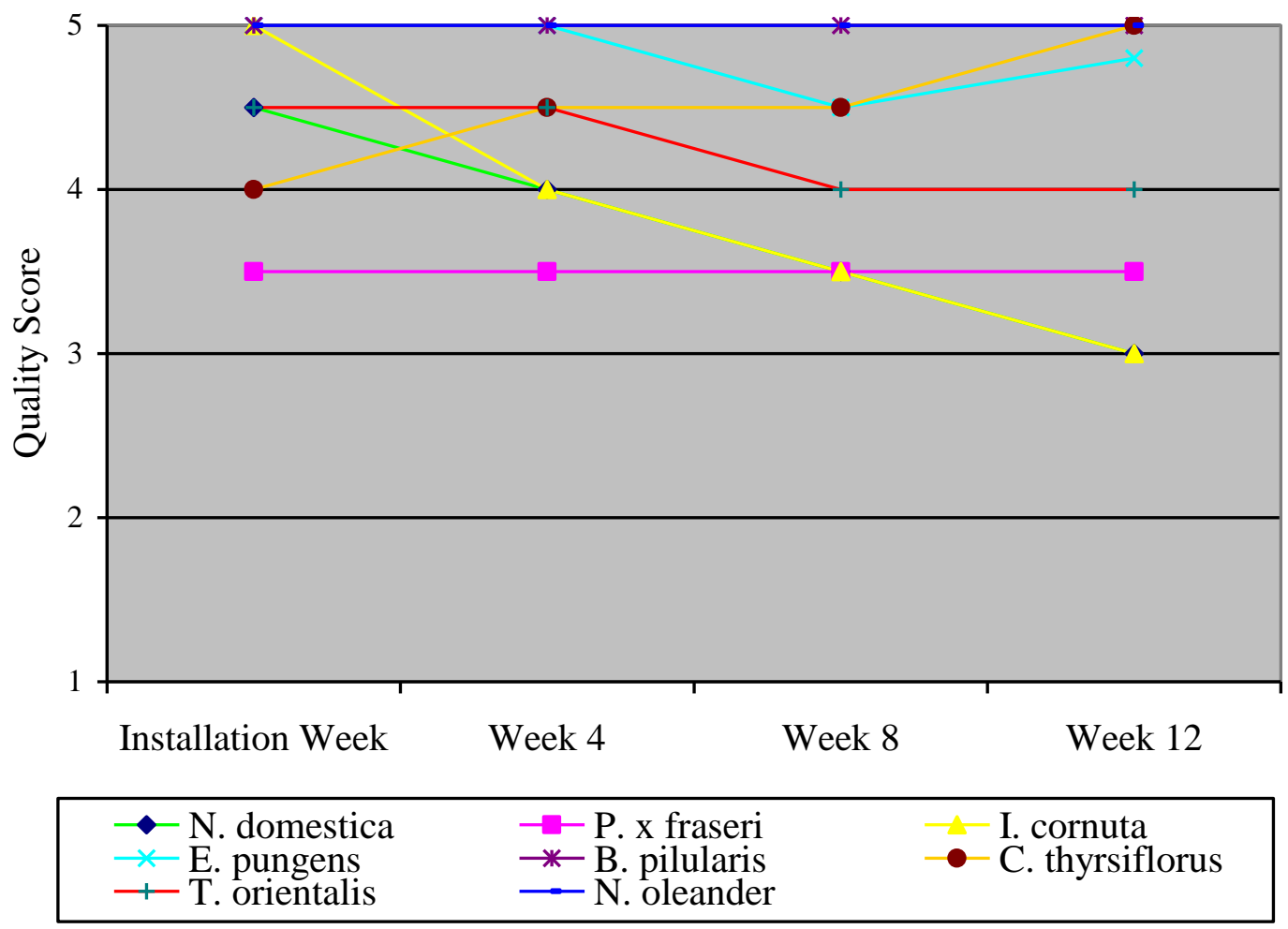

Figure 21: Quality Results of Shrubs Planted in $40 \%$ Sand, $40 \%$ Peat Moss, and 20\% Perlite Media

$\underline{\text { Nandina domestica, }} \underline{\mathrm{P}} \times \mathrm{x}$ fraseri, and $\underline{\mathrm{I}}$. cornuta showed a consistent decline in quality score over the 12 week period of testing for Phase II. Nandina domestica at the beginning of the project was a healthy green with minimal to no damage and was given a 
score of 4.5. A steady decline from installation to week 12 showed a significant decline in quality score from 4.5 to 3.0. Brown necrotic margins and tips, with chlorotic leaves, best describe all the species samples throughout the testing period. Also, little growth was measured from the beginning to the end of phase II. Photinia. $\mathrm{x}$ fraseri exhibited poor quality appearance from the start of this phase with a score of 3.5 and scores remained at

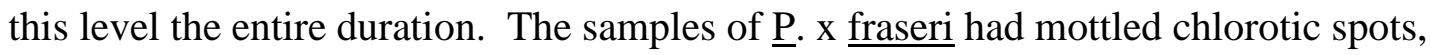
mottled red discoloration, and minimal growth. Ilex cornuta started very healthy, green, with minimal damage and immediately developed necrotic flecking on leaves which spread to almost every leaf. Samples had flecking on $100 \%$ of the leaves, with leaf abscission, leaf margin necrosis, minimal growth, but lots of green on leaves still present. Scores started at 5.0 and ended at 3.0.

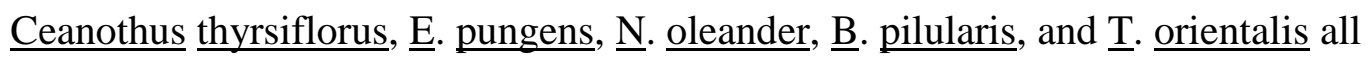
remained above an aesthetic score of 4.0. Thuja orientalis had a score of 4.5 at the onset of this phase and declined slightly, while still remaining above 4.0. Yellow discoloration at top of canopy was present on all samples of this species. Ceanothus thyrsiflorus on the other hand increased from 4.0 at the beginning to 5.0 by the end of the phase. Early necrotic margins on some (approximately 10\%) of the leaves prompted the lower score. Good flowering, consistent growth, and minimal damage is the reason for an increase in overall aesthetics of this species. Eleagnus pungens was consistently above 4.5 with a score of 5.0 through most of the period; however, a few of the leaves contained some interveinal chlorosis dropping the scores by a half a point to 4.5 from 5 between week 4 and 8. Eventually this score increased back to 5.0 at the end of testing. Baccharis 
pilularis and $\underline{\underline{N}}$. oleander had no visible damage to plants and consistent growth from week to week, and scored a 5.0 throughout the experiment.

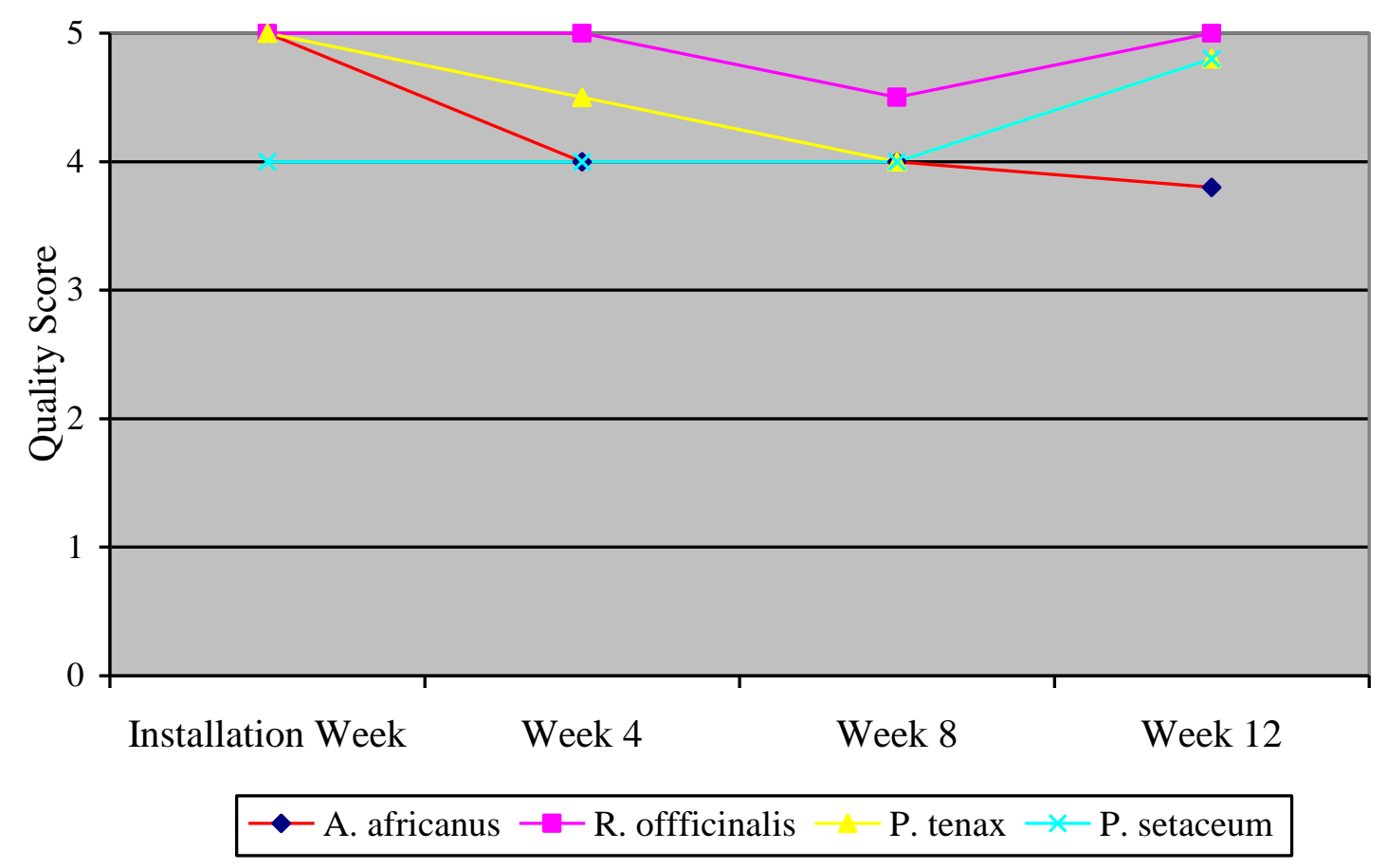

Figure 22: Quality results of Herbaceous Perennials Planted in 40\% Sand, 40\% Peat Moss, 20\% Perlite Media

The four herbaceous perennials tested in Phase II were $\underline{A}$. africanus, $\underline{\text { R. officinalis, }}$ P. tenax, and $\underline{\text { P. }}$ setaceum, each had quality scores that did not drop below 3.8. Agapanthus africanus was the only herbaceous perennial to drop below 4.0 and to decline steadily in Phase II, with a score of 5.0 to 3.8 throughout the experiment. The reason for this decline in scores was due to leaf wilting, chlorosis present on approximately $20 \%$ of the leaves, and tip necrosis present on some leaves. Phormium tenax dropped from 5.0 to 4.0 from installation to week 8 but then climbed up to 4.5 . Aesthetic score 4.0 was given due to some of the leaves exhibiting bronze flecking and tips of all plants had 
minor necrosis on them. Pennisetum setaceum was consistent throughout, exhibiting quality scores of 4.0 until the final week when it rose to 4.5 . Very little change was noted

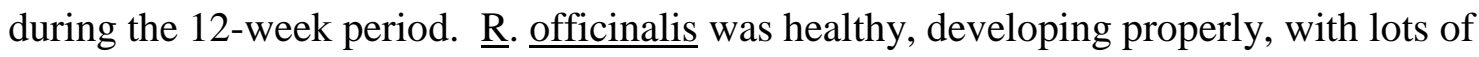
new growth observed on flowers, and minimal visual stress to plant observed. $\underline{\mathrm{R}}$. officinalis was given a 5 at installation, week 4 and week 12, while on week 8 it received a 4.5.

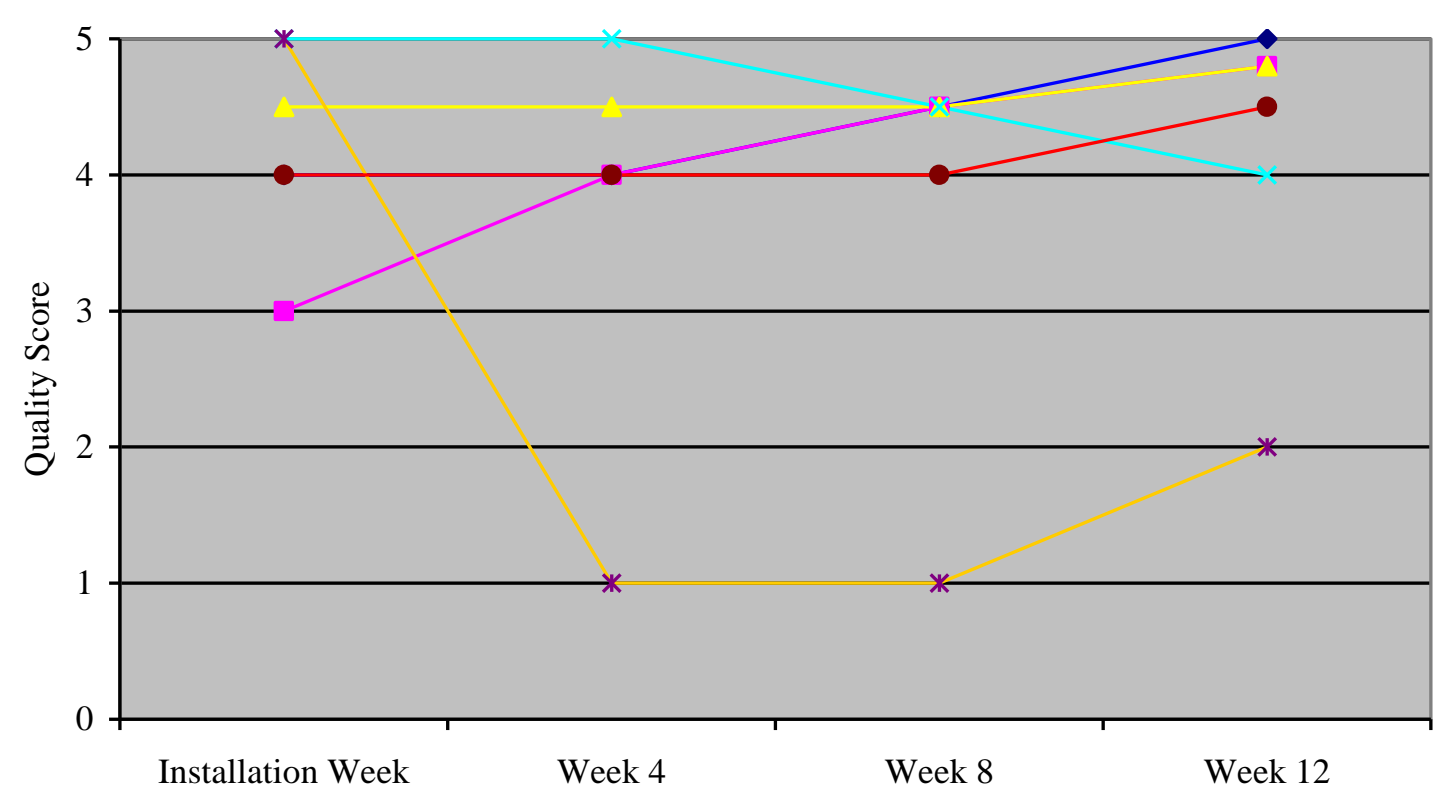

$\rightarrow \bullet$ Heuchera $\rightarrow-$ L. japonica - V. major $\rightarrow-$ H. helix $*$ Gazania $\rightarrow-$ C. griseus

Figure 23: Quality Results of Groundcovers Planted in 40\% Sand, 40\% Peat Moss, and $20 \%$ Perlite Media

Animal's damaged Gazania spp. in phase II, as they did in phase I, so plants were scored based on what was left undamaged. Scores were inaccurate, however, and do not reflect real quality changes so they should not be considered in the results. All other 
groundcovers remained above the aesthetic satisfactory limit of 3.0. Hedera helix decreased only slightly in quality from 5.0 at installation and week 4 to 4.5 at week 8 and 4.0 at week 12 . The only plant damage present on $\underline{\mathrm{H}}$. helix was marginal necrosis and necrotic flecking on underside of leaves.

Consistent and similar growth patterns were observed from the results on

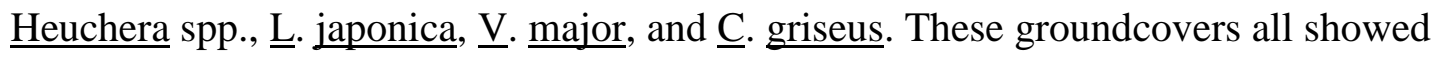
consistent growth from installation week to week 12. Lonicera japonica was installed with an aesthetic score of 3.0 due to tip necrosis; discoloration on leaves and chlorosis was present on samples. After installation, $\underline{\mathrm{L}}$. japonica increased from 3.0 to 4.8 in aesthetic scoring due to major growth, no new damage present, and healthy plant color.

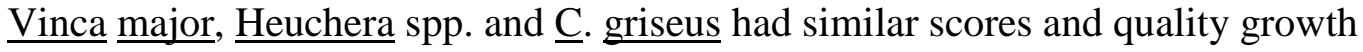
throughout. These species never dropped below 4.0 and was scored as high as 4.8. All samples showed new growth, minimal damage, flowers, and over $90 \%$ of plants were healthy. 


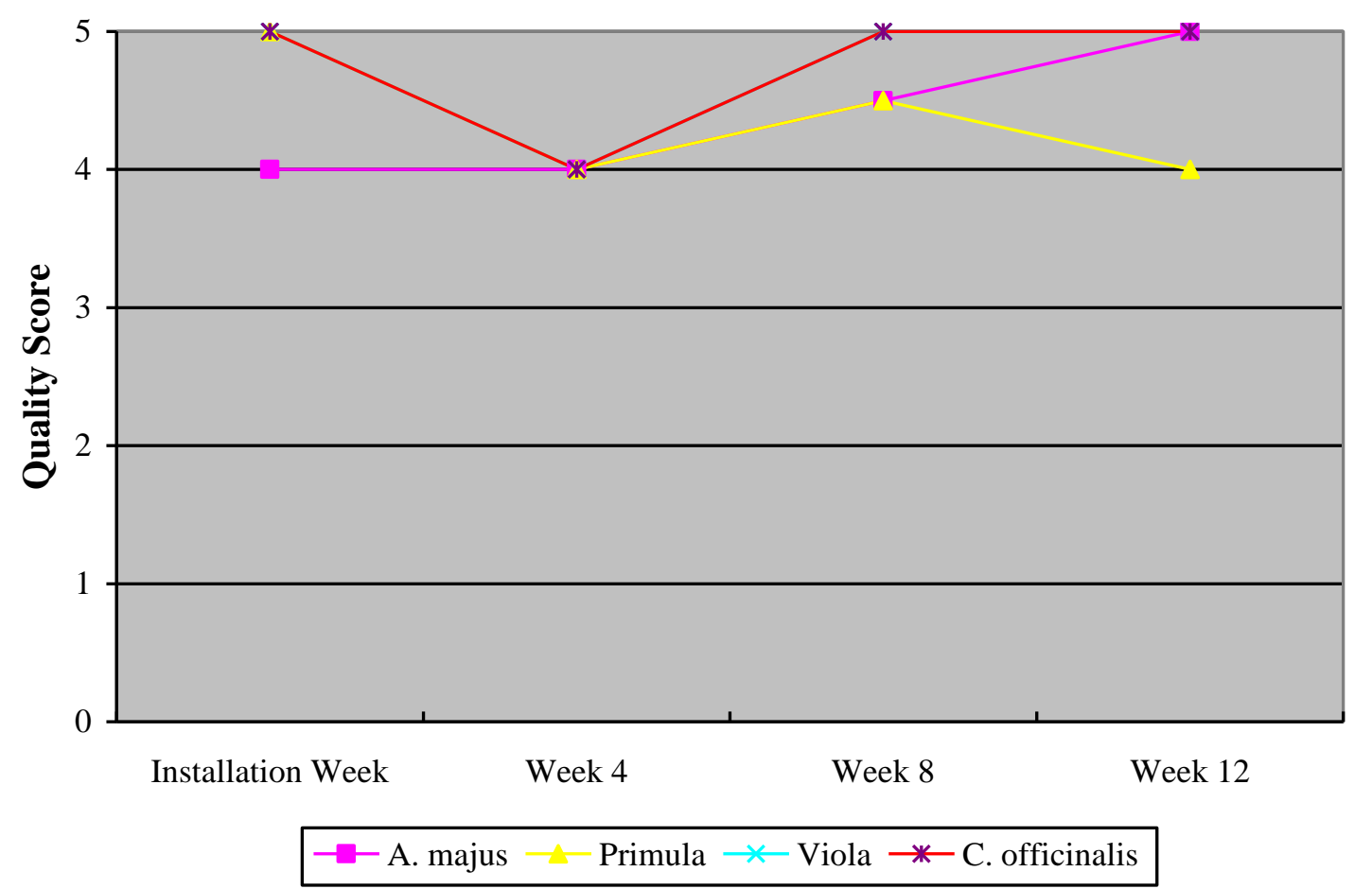

Figure 24: Quality Results of Annuals Planted in 40\% Sand, 40\% Peat Moss, and 20\% Perlite Media

Annual quality scores never dropped below 4.0 and all plant species received a score of 5.0 at some point in phase II. Antirrhinum majus was the only annual that started at a quality rating of 4.0. Steady growth from throughout was prevalent with flowers present and leaves with minimal to no damage. Primula spp. started at a quality score of 5 and declined over the 12 week period to 4.0. This species never dropped below 4.0.

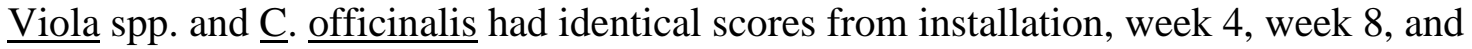
week 12 with a 5.0, 4.0, 5.0, and 5.0, respectively. Annuals had an abundance of flowers, with lots of new growth, minimal to no damage on plants, and healthy appearance. 


\section{Media Results and Analysis}

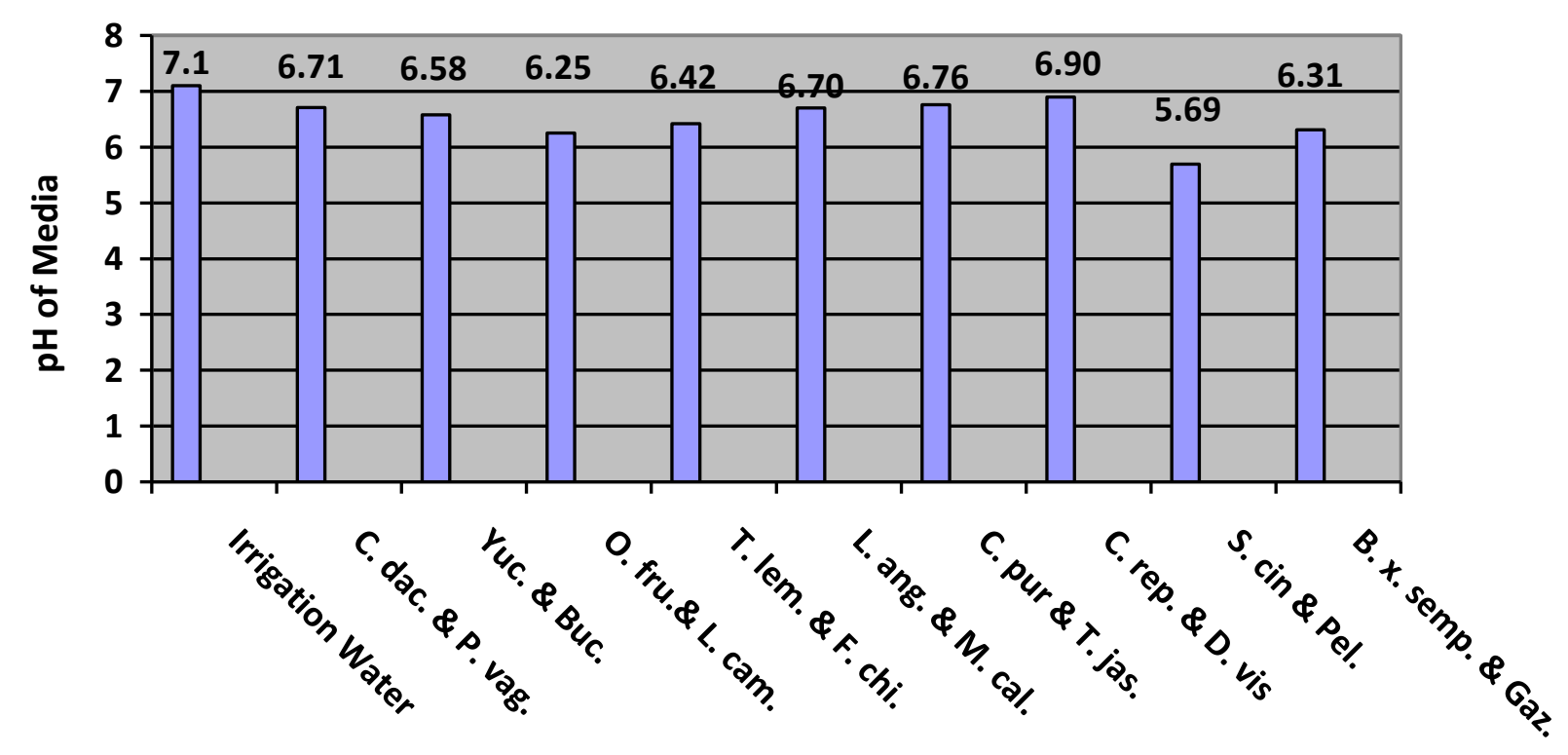

Plant Species

Figure 25: pH Results for 40\% Sand, 40\% Peat Moss, and 20\% Perlite Media (Phase I, Week 4)

The first soil samples were taken on September 19, 2008, the fourth week of Phase I of the project and yielded similar $\mathrm{pH}$ levels for all sets of plants. The $\mathrm{pH}$ of media for Phase I week 4 ranged from 5.69 to 6.90 , with a mean value of 6.48 throughout the nine combined soil samples (Fig. 25). 


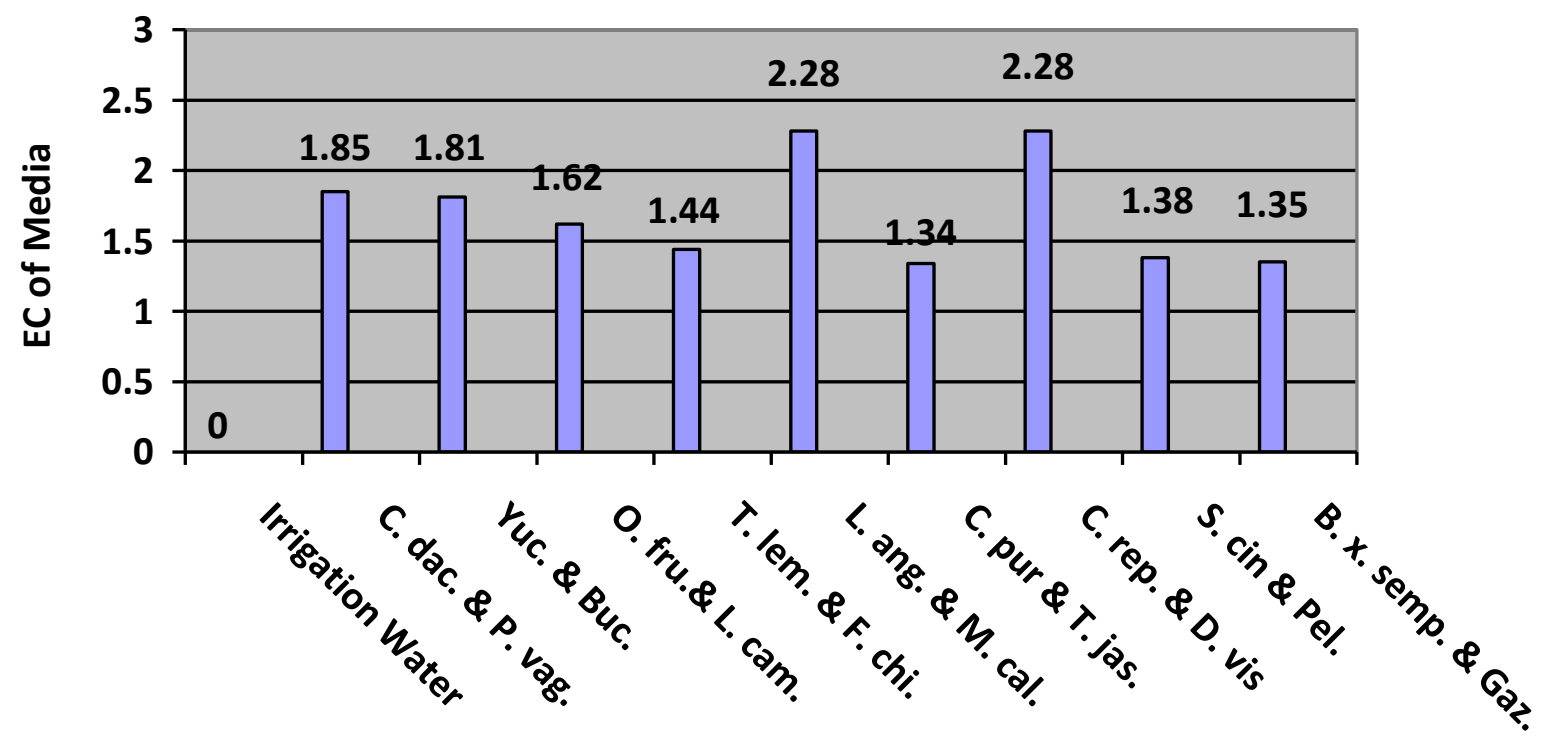

Plant Species

Fig. 26: Electrical Conductivity $\left(\mathrm{EC}_{\mathrm{e}}\right)$ Results for $40 \%$ Sand, $40 \%$ Peat Moss, and $20 \%$ Perlite Media (Phase I, Week 4)

Electrical conductivity was measured in media from combined samples. The Electrical conductivity for Phase I week 4 ranged from 1.34 to 2.28 , with a mean value of 1.71 throughout the nine combined soil samples (Fig. 26). 


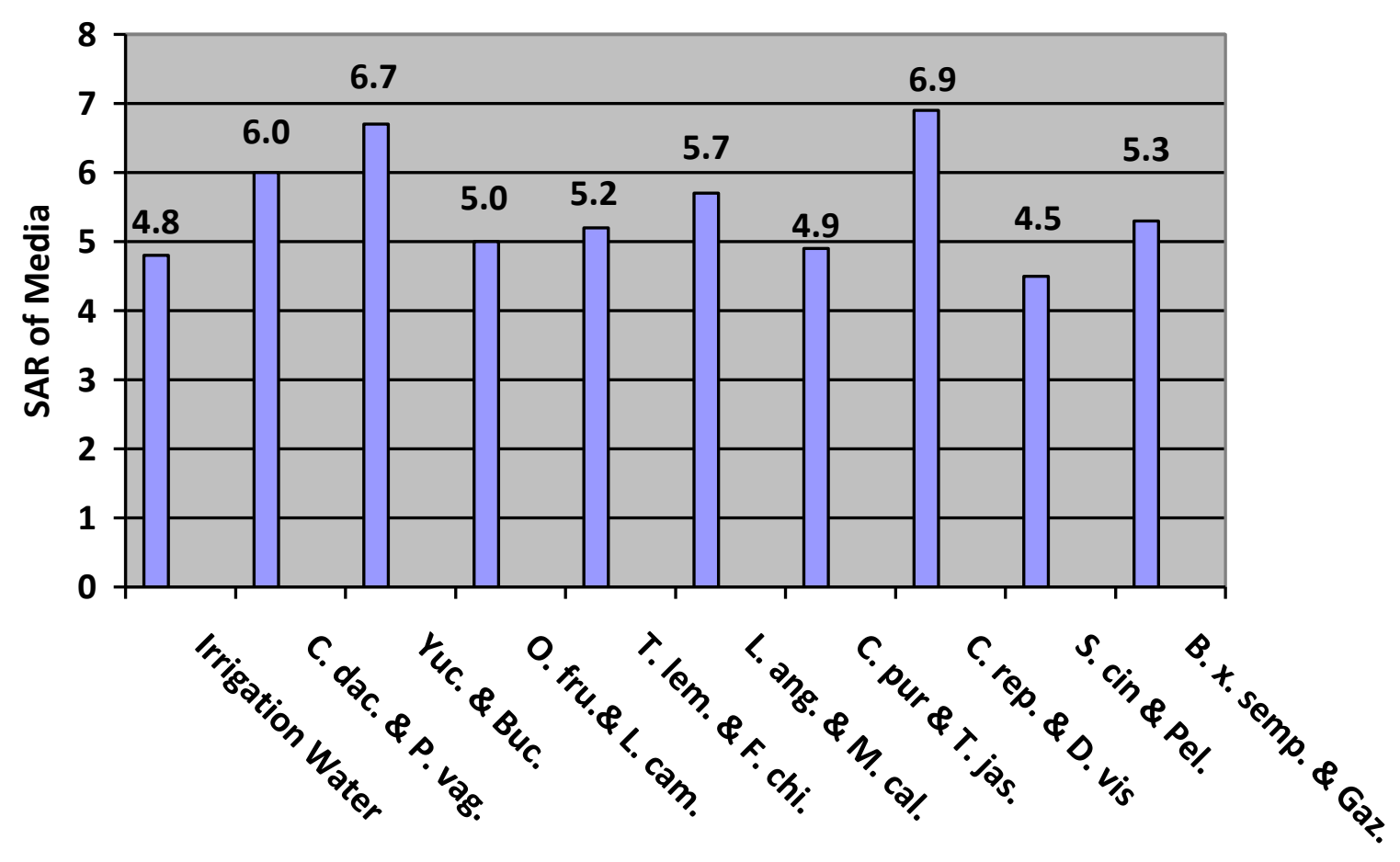

Plant Species

Fig. 27: Sodium Adsorption Ratio (SAR) Results for 40\% Sand, 40\% Peat moss, and $20 \%$ Perlite (Phase I, Week 4)

The Sodium Adsorption Ratio of media for Phase I week 4 ranged from 4.9 to 6.9, with a mean value of 5.58 throughout the nine combined soil samples (Fig. 27). 


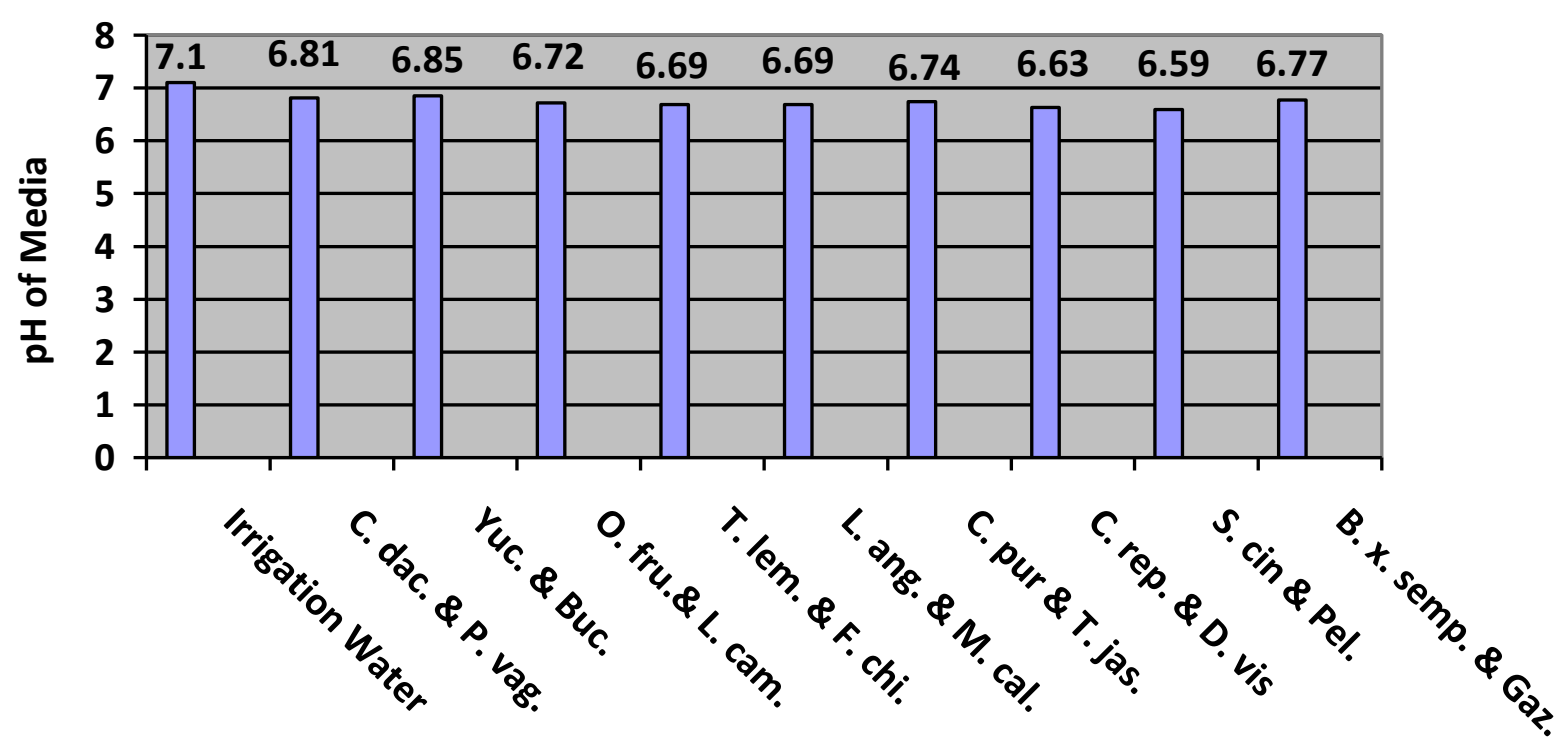

Plant Species

Fig. 28: pH Result for 40\% Sand, 40\% Peat Moss, and 20\% Perlite Media (Phase I, Week 12)

The $\mathrm{pH}$ of media for Phase I week 12 ranged from 6.59 to 6.85 , with a mean value of 6.72 throughout the ten combined soil samples (Fig. 28). 


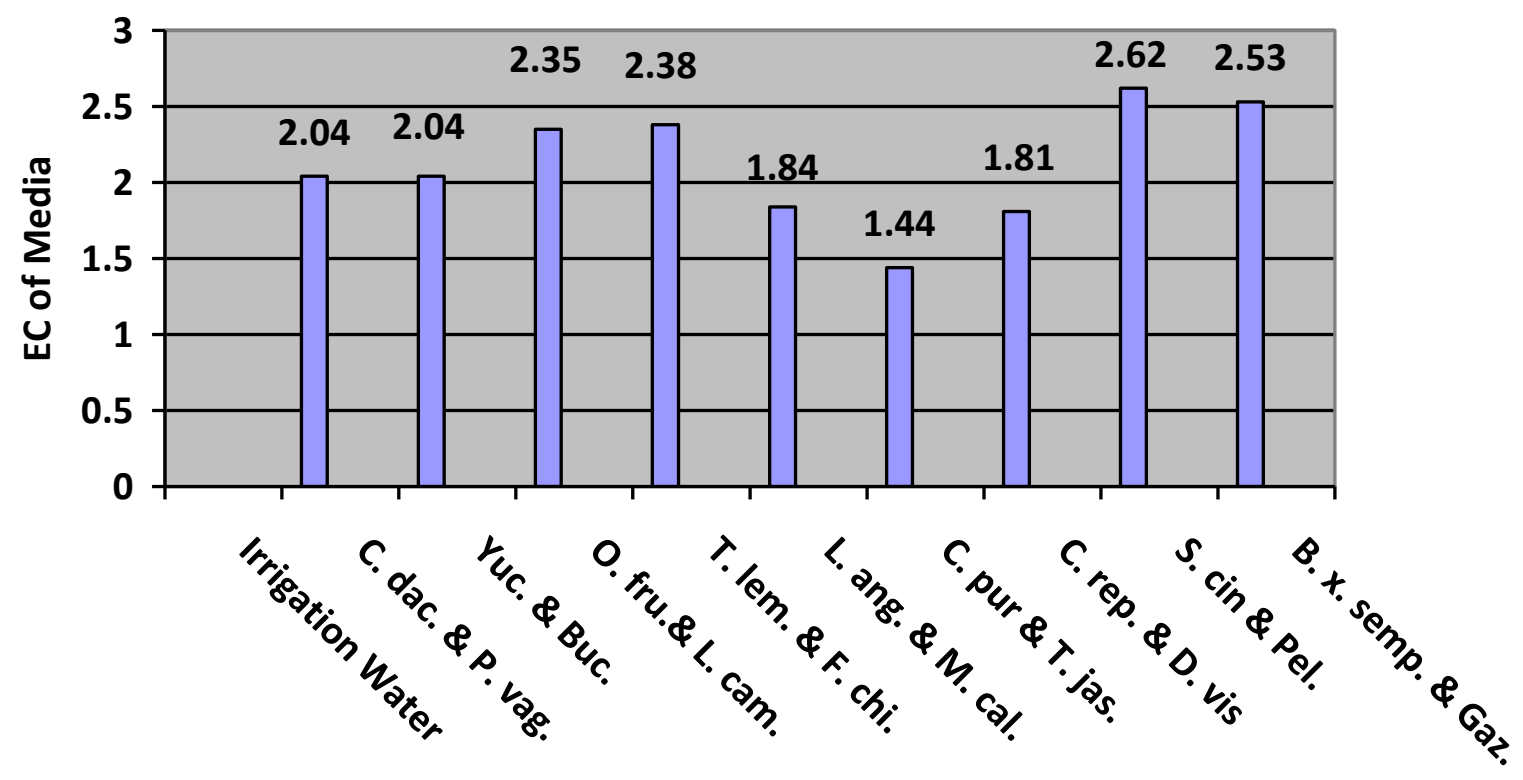

Plant Species

Fig. 29: Electrical Conductivity $\left(\mathrm{EC}_{\mathrm{e}}\right)$ Results for $40 \%$ Sand, $40 \%$ Peat Moss, and $20 \%$ Perlite Media (Phase I, Week 12)

The Electrical Conductivity of media for phase 1 week 12 of the project ranged from 1.44 to 2.62 and had a mean value of 2.12 throughout the ten combined samples (Fig. 29). 


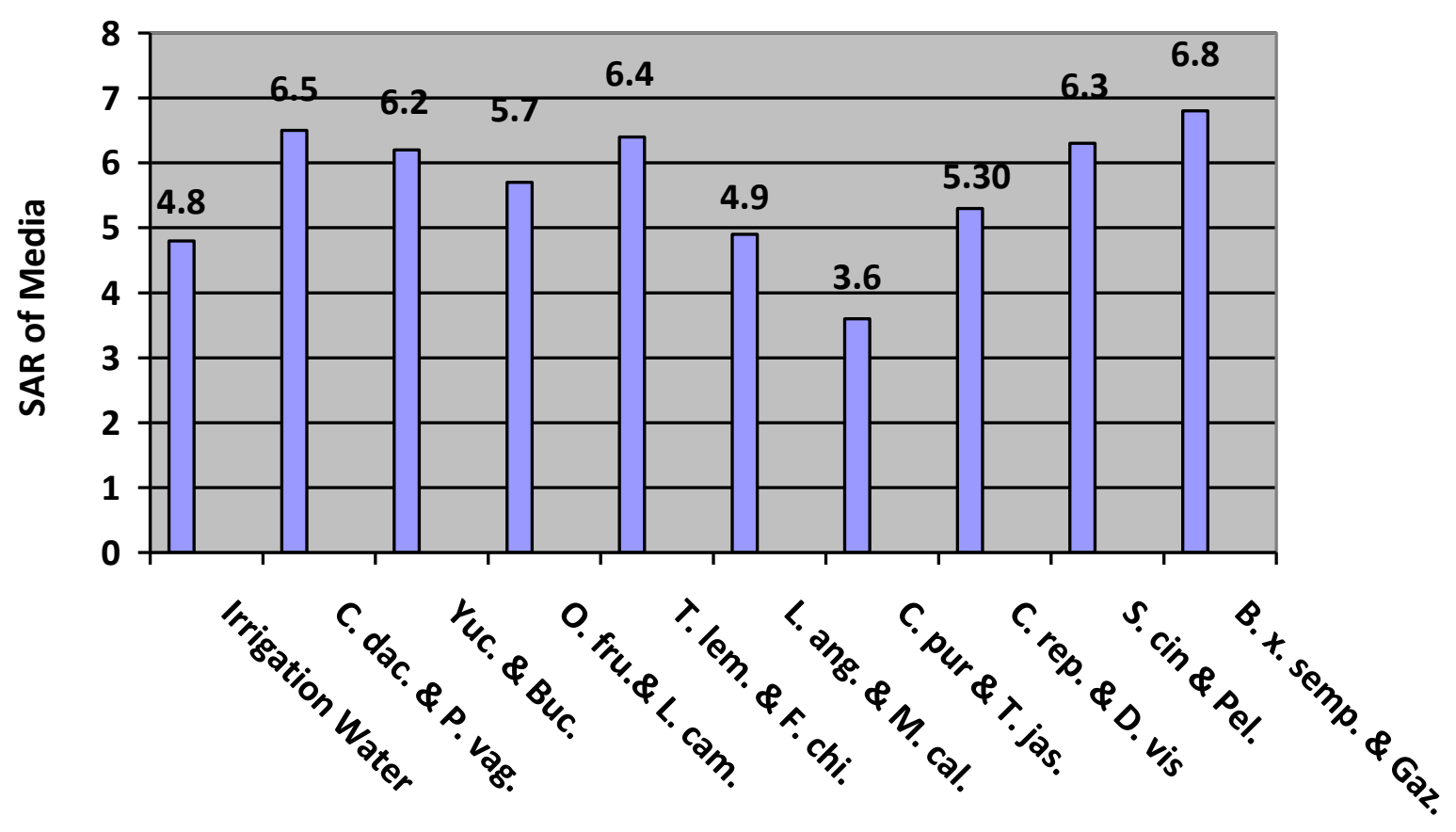

Plant Species

Fig. 30: Sodium Adsorption Ratio (SAR) Results for 40\% Sand, 40\% Peat Moss, and $20 \%$ Perlite (Phase I, Week 12)

The Sodium Adsorption Ration of media for Phase I week 12 of the project ranged from 3.6 to 6.8 and had a mean value of 5.74 throughout the ten combined samples.

\section{Water Results and Analysis}

The water analysis from App. 5a represents samples that were extracted from the irrigation system at installation week of Phase I. Results revealed above normal $\mathrm{EC}_{\mathrm{w}}$ levels with possible moderate problems when used for irrigation. SAR of the water sample is at normal level 4.8, as is the $\mathrm{pH}$ is 7.1. All of the cations, such as sodium $(201 \mathrm{mg} / \mathrm{L})$ are at acceptable levels in the water analysis. Anions were all at acceptable levels except for chloride which is well above normal, and in the severe problem range of suitability for irrigation. 
The analysis in App. 5b showed that the levels of iron, total dissolved solids (TDS) and high alkalinity could be problematic, to highly problematic for micro irrigations systems, such as drip systems.

The water analysis in App. 5c represents samples that were extracted from the irrigation system at week 11 of Phase 1. Results revealed above normal EC levels with possible moderate problems when used for irrigation. SAR of the water sample was at normal level 4.8, as was the $\mathrm{pH}$ is 7.1. All of the cations, such as sodium $(203 \mathrm{mg} / \mathrm{L})$ are at acceptable levels in the water analysis. Anions are all at acceptable levels except for chloride, which were well above normal, and in the severe problem range of suitability for irrigation. Nitrate is much higher in this water analysis and in the possible problem range for irrigation.

The analysis (App. 5d) showed that the levels of iron, total dissolved solids (TDS) and high alkalinity could be problematic, to highly problematic for micro irrigations systems, such as drip systems. In this water sample, levels of alkalinity were much higher than at installation week, though levels of iron have decreased from installation week. 


\section{$\underline{\text { Discussion }}$}

\section{Phase I}

\section{Grasses and Grass-like Plants}

Throughout the duration of the experiment, Yucca spp. showed only slight reaction to the recycled irrigation water, as shown in the tips of the leaves, where salts built up in the plant and caused damage. Yucca spp. plants remained acceptable in quality for use in the landscape in both media types (Fig.13 and 14), having only slight reductions in quality appearance from tip burn. This tip burn could have been in direct correlation with high levels of chloride in the recycled water (App. 5a and c). According to Pettygrove and Asano (1985) plants can be damaged when chloride levels in water are above $\geq 350 \mathrm{mg} / \mathrm{L}$. The results summarized in Fig. 31 indicate that there was no consistent correlation between chloride levels and quality scores. Plants at high chloride levels showed high quality scores, as did plants with low quality scores. Chloride toxicity in grasses and grass-like plants is species dependent.

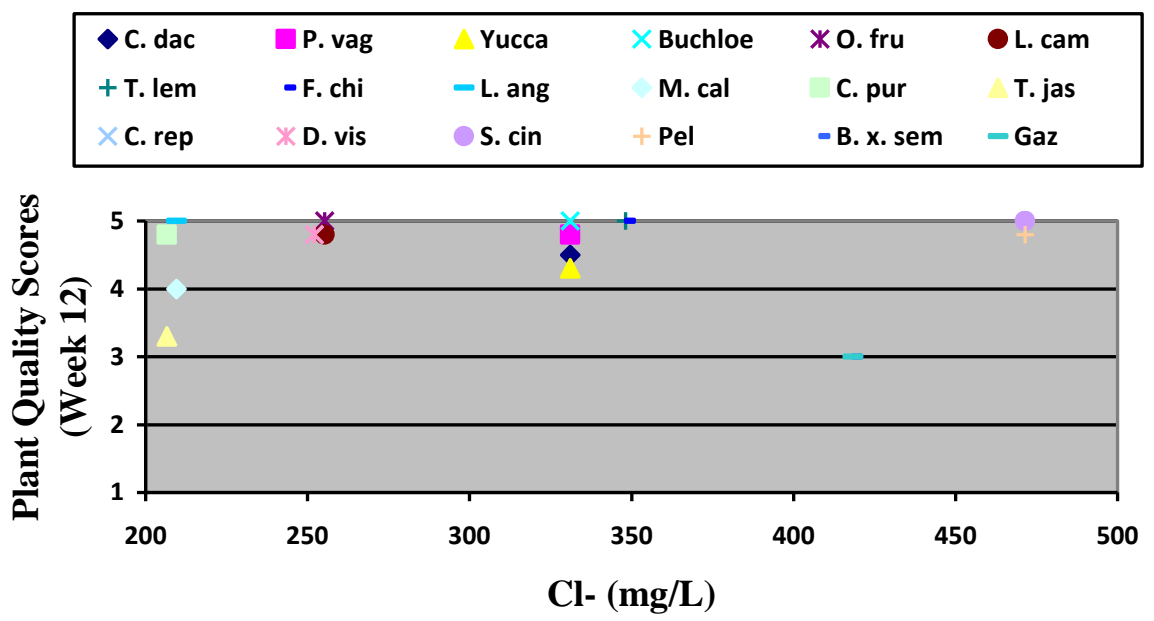

Fig. 31: Effects of $\mathrm{Cl}^{-}$on Plant Quality Scores 
Throughout the duration of this project, Buchloe spp. exhibited no signs of recycled water stress, and only went slightly dormant in the winter months with a slight yellow discoloration. Buchloe spp. (Fig $13 \&$ 14) in each media had similar responses throughout the experiment. Normal quality scores can be attributed to the presence of nitrogen, phosphorus, and potassium in recycled water irrigation (App. 5) and media (App. 6) after irrigation. These nutrients were beneficial in plant growth and development.

Grasses Paspalum vaginatum and Cynodon dactylon (Fig. 13 \& 14) showed a decline in quality scoring from week 20 to week 28 (coldest winter temperatures). These grasses increased in quality scoring during the last 4 weeks of the project (milder spring temperatures), which lead to the conclusion that low quality scores were in direct correlation with seasonal climatic changes, and not recycled water irrigation. Although plant quality results were similar in both media types, plants were more established and had overall more growth in the media consisting of $40 \%$ sand, $40 \%$ peat moss, and $20 \%$ perlite. The quality score comparison of each species in Fig.13 and 14 were consistently higher in the $40 \%$ Sand, $40 \%$ Peat Moss, and $20 \%$ Perlite. This could be attributed to higher water and nutrient holding capacity in a more peat moss based media, as opposed to the $80 \%$ sand and $20 \%$ peat moss. Media results also indicated only a slight increase in $\mathrm{pH}$ (6.71 to 6.81$)$, EC (1.85 ppm to $2.94 \mathrm{ppm})$, and SAR (6.0 to 6.5) throughout the duration of the project. All of these results remain in the safe to moderate levels, according to Pettygrove and Asano (1985), in Table 1. Common nutrients such as 
Nitrogen, Phosphorous, and Potassium were present in the media in small amounts, aiding in plant growth and development.

These grasses and grass-like plants can be irrigated with recycled water and react positively to the level of usable nitrates in water and soil after irrigation. In Appendix 5a and $5 \mathrm{c}$ you can see that, nitrate levels in the recycled water remained approximately in the low to moderate level from week 1 to week $12(73.4 \mathrm{mg} / \mathrm{L}$ to $64.6 \mathrm{mg} / \mathrm{L})$. Nitrogen, Phosphorous, and Potassium were present in recycled water and acted as fertilizer to grasses and grass-like plants. Levels of each element aided in the development of new growth on plant material. As levels of each element increased or decreased (Fig. 32, 33, and 34) there is no relation to quality scores. This would indicate that grasses and grasslike plants that were tested react differently to a range of these elements in the soil. The selection of these species of grasses, therefore, should be based on seasonal weather requirements and the positive effects of Paso Robles recycled water. 


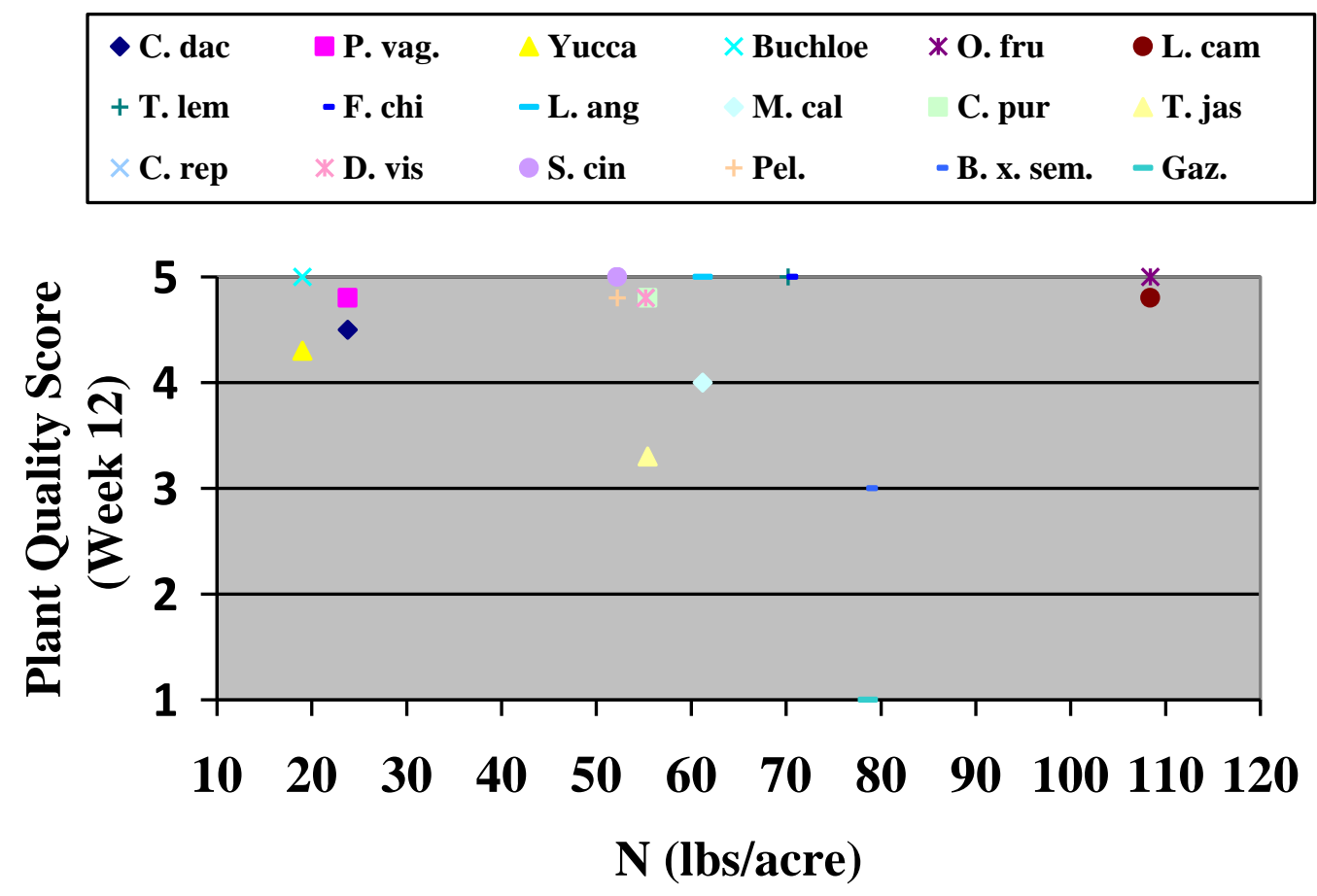

Fig. 32: Effects of Nitrogen in the media on Plant Quality Score

\begin{tabular}{|c|c|c|c|c|c|}
\hline C. dac & P. vag & Yucca & $\times$ Buchloe & ЖO. fru & L. cam \\
\hline + T. lem & -F. chi & - L. ang & M. cal & C. pur & T. jas \\
\hline$\times$ C. rep & D. vis & S. cin & + Pel. & - B. x. sem. & - Gaz. \\
\hline
\end{tabular}

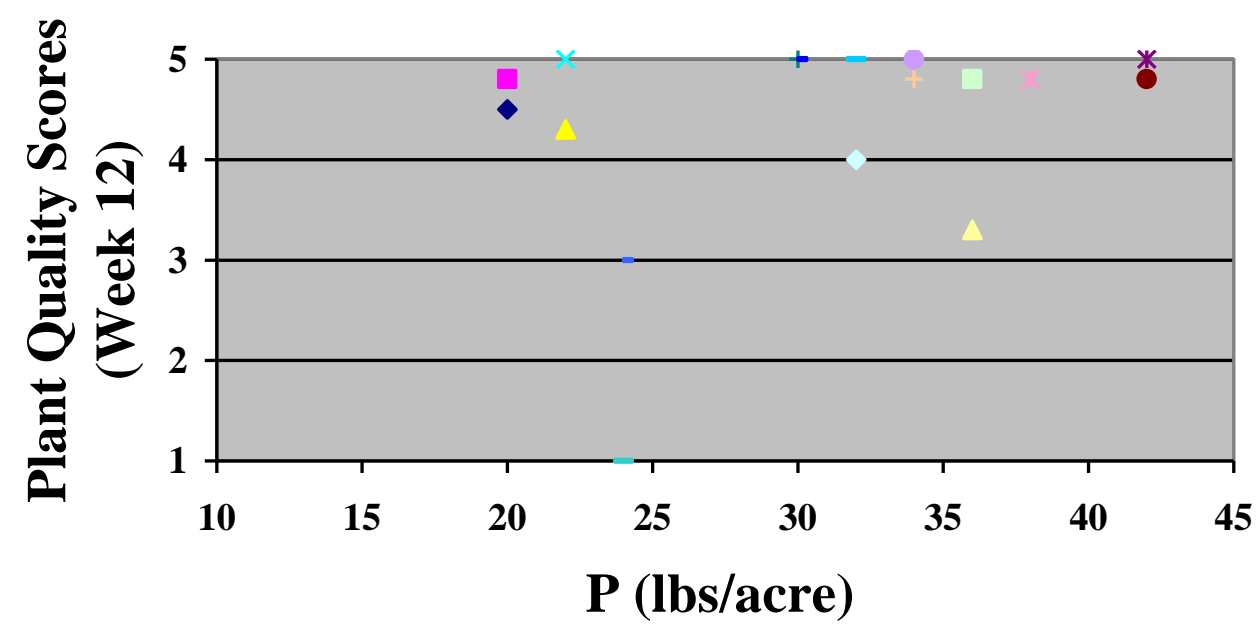

Fig. 33: Effects of Phosphorous in the media on Plant Quality Scores 


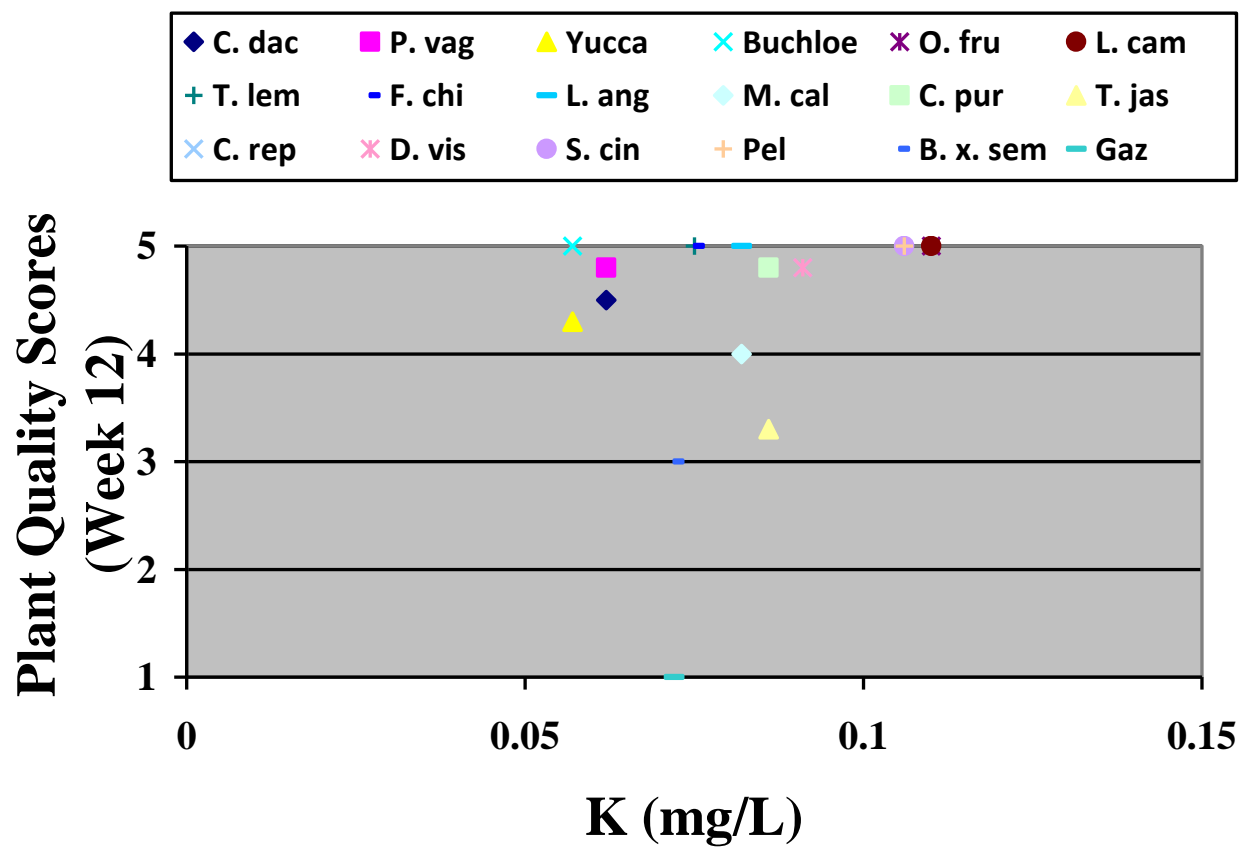

Fig. 34: Effects of Potassium in Media on Plant Quality Scores

\section{Herbaceous Perennials}

Structural problems with the $80 \%$ sand and $20 \%$ peat moss media were the cause of the death of all of the samples of Fragaria chiloensis and; therefore, cannot be attributed to recycled water irrigation. The structural problems consisted of too much sand and not enough peat moss. In the $40 \%$ sand, $40 \%$ peat moss, and $20 \%$ perlite, the appearance of Fragaria chiloensis remained above the acceptable limit for use in the landscape when recycled water is used for irrigation (Fig.15 and Fig. 16). Some minimal recycled water stress could be seen on leaves that had interveinal chlorosis and bronzing, symptoms of chloride and sodium stress. Although salinity increased in the soil from 1.44 mmhos to 2.38 mmhos, and SAR increased from 6.0 to 6.5 , plant quality scores 
were unaffected because stress was only present on a few leaves. In Fig. 35 you can see that levels of $\mathrm{EC}_{\mathrm{e}}$ did not affect quality scores. Nitrate levels in media increased over three times (10.4 ppm to $35.1 \mathrm{ppm}$ ); phosphorus and potassium were found in small amounts within the soil, thus causing plant growth in Fragaria chiloensis and consistent quality improvement.

\begin{tabular}{|lccccc|}
\hline C. dac. & P. vag & Yucca & X Buchloe & XO. fru & O. cam \\
+ T. lem & - F. chi & L. ang & M. cal & C. pur & T. jas \\
X. rep & X. vis & S. cin & + Pel. & - B. x. sem & - Gaz \\
\hline
\end{tabular}

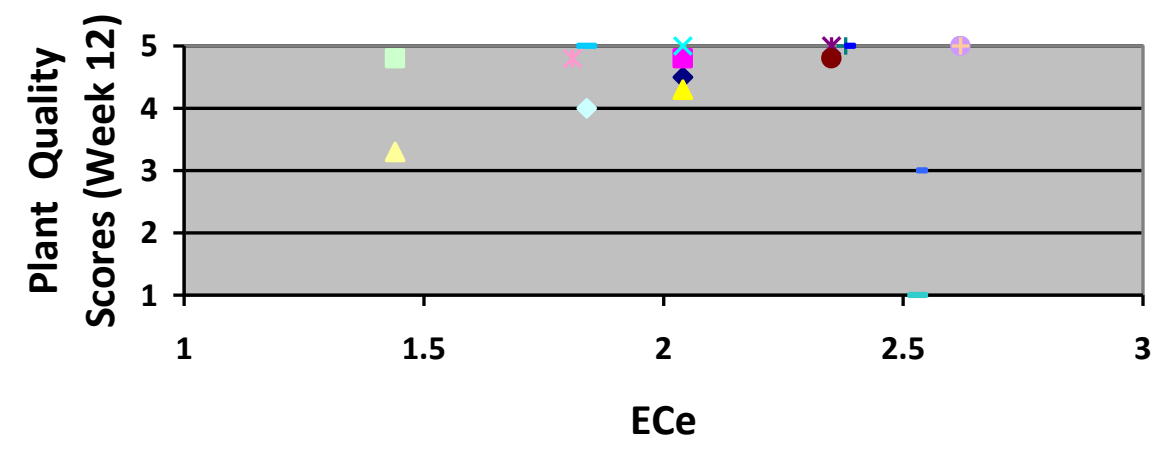

Fig. 35: Effects of $\mathrm{EC}_{\mathrm{e}}$ on Plant Quality Scores

$\underline{\text { Lantana }} \underline{\text { camara }}$ and Tagetes lemmonii showed no adverse affects to the recycled water. Both species grew well before frost damage killed Lantana camara and caused major dieback in Tagetes lemmonii, for all samples, in both media types. Before Lantana camara died, plant samples had much new growth and showed no recycled water stress. This large increase in growth could be attributed to the available nitrogen, phosphorous, and potassium present in the media. Nitrogen increased from $17.7 \mathrm{ppm}$ to $54.2 \mathrm{ppm}$, three 
times the starting amount; phosphorous increased almost three times from 8 ppm to 21 ppm; postassium increased from $0.737 \mathrm{meq} / \mathrm{L}$ to $0.933 \mathrm{meq} / \mathrm{L}$. (App. 6). Tagetes lemmonii, after frost damage, showed new green growth and finished with acceptable quality scores by the conclusion of the experiment. Media nitrogen and phosphorus increased throughout the project from $10.4 \mathrm{ppm}$ to $35.1 \mathrm{ppm}$ and $5 \mathrm{ppm}$ to $15 \mathrm{ppm}$, respectively. Potassium slightly decreased from 0.659 to 0.629 . The media $\mathrm{pH}, \mathrm{EC}_{\mathrm{e}}$, and SAR, for Tagetes lemmonii and Lantana camara, were in the safe ranges for acceptability in the landscape.

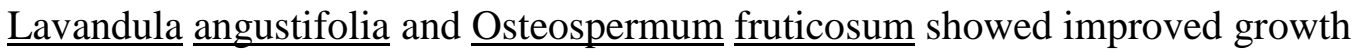
in the recycled water for all samples, of both media types. Increases in nitrate, phosphorous, and potassium levels, in the media and throughout the project, were responsible for the increase in growth of these plants. Osteospermum fruticosum media's nitrate level increased from $17.7 \mathrm{ppm}$ to $54.2 \mathrm{ppm}$ and the Lavandula angustifolia media increased from $15.3 \mathrm{ppm}$ to $30.6 \mathrm{ppm}$ (App. 6).

There were no major effects of recycled water on the herbaceous perennials tested in Phase 1. Overall levels of N, P, and K were at below normal levels for fertilizers but could have been responsible for the nutritional aid in growth and development. Acceptable perennials should be selected not only on tolerance to recycled water but sensitivity to environmental factors, such as temperatures, as seen in the stress caused to

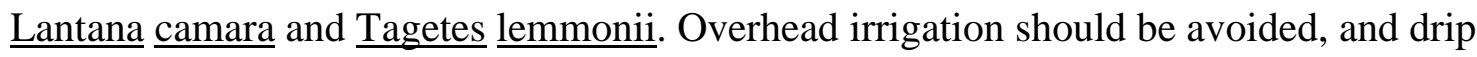
irrigation encouraged on all types of herbaceous perennials, due to the buildup of harmful salts when direct contact is made with the leaves of plants. Media $\mathrm{pH}$ for all herbaceous perennials remained at normal levels throughout the project. 


\section{$\underline{\text { Shrubs }}$}

Trachelospermum jasminoides was the only shrub that showed major damage from recycled water and its use should be discouraged in the landscape when recycled water is being used. Not only did samples in both media types show major stress but growth was stunted despite nitrate levels doubling throughout the duration of the project. Quality scores were below the acceptable limit for landscape use, based on the criteria used in this project. The interesting fact about the media results was that of all samples in the experiment, $\mathrm{EC}_{\mathrm{e}}$ increased the least in the media of Trachelospermum jasminoides and Cistus purpureus, and had the lowest value from start to finish (1.34 mmhos to 1.44 mmhos) compared to other samples. The SAR value was much lower than other samples and decreased throughout the duration of the project (4.9 to 3.6). While Trachelospermum jasminoides decreased in quality, Cistus purpureus grew normally, possibly due to the increase in nitrate levels (14.9 $\mathrm{ppm}$ to $27.7 \mathrm{ppm}$ ) which could have aided in the development of new growth.

$\underline{\text { Myrica }}$ californica also showed stress signs from the recycled water with necrotic spots on leaves, and chlorosis and necrosis on new growth. All samples in both media types never dropped below the acceptable range for use in the landscape because plant samples showed growth from week to week and a majority of the leaves were healthy. Nitrate, phosphorus, and potassium levels in the media doubled throughout experiment $15.3 \mathrm{ppm}$ to $30.6 \mathrm{ppm}, 12 \mathrm{ppm}$ to $16 \mathrm{ppm}$, and $0.646 \mathrm{meq} / \mathrm{L}$ to $0.751 \mathrm{meq} / \mathrm{L}$ (App. 6).

Coprosma repens and Dodonea viscosa were all acceptable plant species for recycled water irrigation and showed minimal to no stress on plants throughout the duration of the project. Soil salinity decreased from $2.28 \mathrm{mmhos}$ to $1.81 \mathrm{mmhos}$ and 
SAR decreased from 6.9 to 5.3, a safe salinity level for plants according to Costello et al. (2003). All shrubs planted in $40 \%$ sand, $40 \%$ peat moss, and $20 \%$ perlite had taller, denser, and healthier growth than shrubs planted in $80 \%$ sand/ $20 \%$ peat moss.

Shrubs should be drip irrigated to avoid burning of leaves from overhead irrigation. Trachelospermum jasminoides should not be irrigated with any form of recycled water if quality results in the landscape are desired. Shrubs should be planted in a media that encourages water-holding capacity, nutrient availability, and has proper leaching capacity to leach harmful accumulations of salts. All samples in Trachelospermum jasminoides showed some form of chlorosis, and white discoloration on leaves, common of chloride toxicity (Costello et al. 2003). Although levels of sodium in the water samples were low to moderate and SAR values decreased throughout the project (App. 5), Trachelospermum jasminoides was categorized as a salt sensitive plant, (App. 2) and effects on quality were apparent. As seen in Fig. 31-36 there were no significant consistency in Quality Scores to ECe, $\mathrm{Na}^{+}, \mathrm{Cl}^{-}, \mathrm{N}, \mathrm{P}$, and $\mathrm{K}$. This would indicate that herbaceous perennials reacted to different levels of these elements and are therefore species dependent.

\section{$\underline{\text { Annuals }}$}

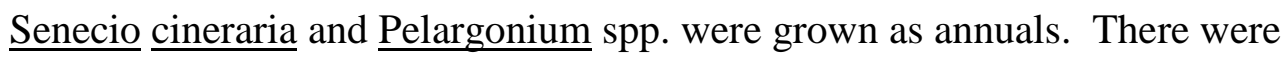
minimal to no stresses on plants in both media types in reaction to consistent recycled water irrigation. Nitrate levels started at a higher level $(24.0 \mathrm{ppm})$ than other plant samples and remained almost constant throughout the experiment (26.1 ppm). $\underline{S}$. cineraria grew well in both media types although plants were bigger, denser, and healthier in the 
$40 \%$ sand, $40 \%$ peat moss and $20 \%$ perlite media. Pelargonium spp. also developed well in reaction to the recycled water and only had minimal stress due to cold weather conditions. The $\mathrm{pH}, \mathrm{EC}_{\mathrm{e}}$, and $\mathrm{SAR}$ all increased throughout the project (App. 6). Plants in $40 \%$ sand, $40 \%$ peat moss, and $20 \%$ perlite had healthier, larger, and denser growth than the $80 \%$ sand and $20 \%$ peat moss media due to poor media structure, which was unsuitable for proper root development.

Begonia $x$ semperflorens-cultorum should only be grown as a summer annual and showed considerable decline during winter months. Not only were plants affected by poor weather conditions, but poor media conditions and necrotic leaf margins were all responsible for the decline of $\underline{\text { Begonia }} \underline{\underline{x}} \underline{\text { semperflorens-cultorum. }} . \mathrm{EC}_{\mathrm{e}}$ almost doubled from 1.35 mmhos to 2.53 mmhos and SAR increased from 5.3 to 6.8 , throughout the duration of the project. Throughout the experiment squirrels consumed- Gazania spp. and; thus, inadequate information was collected to make quality assessment. Media results indicated a large increase in levels of nitrogen throughout the duration of the experiment for these two species of plants (5.6 ppm to $39.3 \mathrm{ppm})$. Media also increased in $\mathrm{pH}, \mathrm{EC}_{\mathrm{e}}$, and $\mathrm{SAR}$, leaving $\mathrm{EC}_{\mathrm{e}}$ and $\mathrm{SAR}$ in moderate levels by the end of the experiment ( $2.53 \mathrm{ppm}$ and $6.8 \mathrm{ppm}$ respectively).

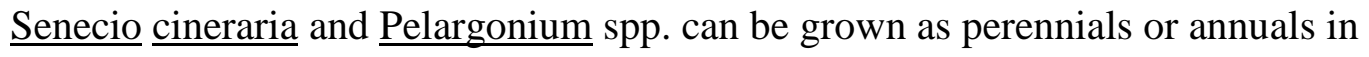
the Central Coast of California, and can be irrigated with recycled water. Begonia $\mathrm{x}$ semperflorens-cultorum is an annual that does not have an acceptable appearance after recycled water irrigation and; therefore, should be avoided for use in the landscape. Annuals should be able to sustain a lifecycle of 3-6 months and have minimal stress to no 
stress $(\leq 10 \%)$ with recycled water irrigation in order to be considered for use in the landscape. Media $\mathrm{pH}$ remained at normal levels throughout the experiment.

Levels of $\mathrm{Na}^{+}$in all samples were low and ineffective to all plant material tested in this phase. In Fig. 35 and $36 \mathrm{Na}^{+}$and ECe levels showed no major or consistent effect of these measurements on quality scores throughout all samples of the project. Useable $\mathrm{N}, \mathrm{P}, \mathrm{K}$, for all plant types could be responsible for the increase in growth in some species. Plant selection should be based on the reaction of plants to useable nutrients $(\mathrm{N}$, $\mathrm{P}$, and $\mathrm{K}$ ) as well as tolerance to $\mathrm{Cl}^{-}$and in some cases $\mathrm{Na}^{+}$. In this phase of the project high levels of $\mathrm{Cl}^{-}$could have a long term effect on soil characterstics and micro-irrigation systems.

\section{Phase 2}

$\underline{\text { Shrubs }}$

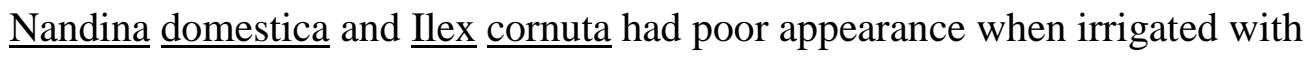
recycled water. Chloride present in the water and in the media from irrigation was most likely responsible for the necrotic flecking and total leaf necrosis on I. cornuta, as well as the minimal new growth, the marginal necrosis, and chlorosis on $\underline{\mathrm{N}}$. domestica. Photinia $\mathrm{x}$ fraseri, at installation, was planted with stress present on samples and remained consistent in aesthetics throughout the duration of the project. Therefore, recycled water was not the cause in the decline of the average quality scores (Fig. 21). Ceanothus

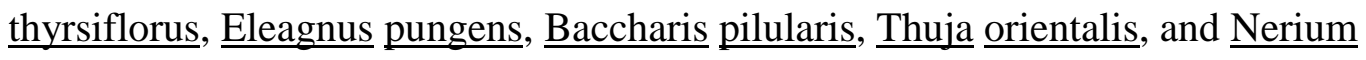
oleander showed new growth and development, with minimal to no stress present on leaves or flowers. 


\section{Herbaceous Perennials}

All herbaceous perennials during the 12-week testing period maintained an above average quality score $(\geq 3.0)$. Agapanthus africanus of the four perennials tested was the only species to show signs of quality decline, but was still acceptable at the end of this experiment. A longer testing period might have revealed a continued decrease in quality for Agapanthus africanus (Fig.22), thus changing the acceptable use of it in the

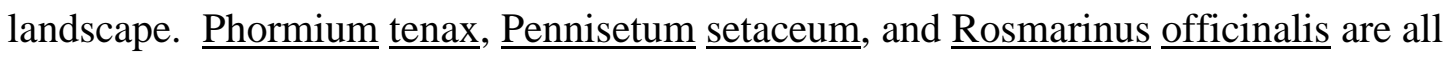
acceptable species to use in landscapes that use recycled water for irrigation. These three species of plants flourished throughout Phase 2 and showed no adverse reactions or stress.

\section{Groundcovers}

Animals destroyed Gazania spp., as in Phase 1, and results were inadequate to assess. Heuchera spp., Lonicera japonica, Vinca major, Hedera helix, and Ceanothus griseus flourished. Heuchera spp. and Lonicera japonica were stressed at installation and improved in quality appearance (Fig. 24). The positive growth reaction with the recycled irrigation water can be attributed to the nitrates and micronutrients that were present in the recycled water. Groundcovers should be irrigated with sub-surface irrigation to avoid burning of leaves. 
Annuals

The annuals Antirrhinum majus, Primula spp., Viola spp., and Calendula

officinalis all had minimal stress on plants, and therefore can be considered tolerant to recycled water (Fig. 25). The low growth on the Primula spp. makes it susceptible to leaf burn when water splashes on the leaves. Necrosis and chlorosis on leaves were symptoms of this occurrence. Flowers continued to grow and leaves that were touched by spray showed no stress. This species was the only annual where careful irrigation techniques should be considered and monitored. The additional annual species tested were unaffected by recycled water.

\section{$\underline{\text { Media and Water Discussion }}$}

According to Costello et al (2003), the acceptable $\mathrm{pH}$ range for proper plant growth in the media should be approximately 5.5-7.0. For $\mathrm{EC}_{\mathrm{e}}$ in media, the range for safe, slight to moderate, and severe conditions are 0.5-2.0, 2.0-4.0, and > 4.0, respectively. The acceptable SAR ranges for generally safe, slight to moderate, and severe conditions are $<6,7-9$, and $>9$ respectively. The $\mathrm{pH}$ ranges for all media types and all species of plants remained in the acceptable range (App. 6). For EC, none of the media samples taken from this project reached the severe condition range. The media for plant species $\underline{\mathrm{L}}$. angustifolia, $\underline{\mathrm{M}}$. californica, $\underline{\mathrm{C}}$. $\underline{\text { repens, }}$, and $\underline{\mathrm{D}}$. viscosa were in the slight to moderate range at week 4 and showed minimal stress to no stress after the recycled water irrigations. As for SAR in the media, all samples were below or approximately at the acceptable threshold for safe media conditions (App. 6). This was expected after 
evaluating water analysis from the start of the project (App. 5) to the end of the project, which showed low to normal levels of $\mathrm{Na}^{+}$.

Media samples indicated that there were macro and micronutrients essential for plant growth present in the media from recycled water irrigation. These nutrients act as a fertilizer for plants, improving plant growth and quality appearance. Of the nutrients and elements added to the media from the recycled water, none were at harmful levels. Nitrogen, phosphorus, and potassium were essential nutrients available to plants in the media and water, which most likely were responsible for the increased growth in many of the plant species.

The biggest challenge when using recycled water for irrigation was the long-term effects it has on media properties and micro irrigation systems. Long term problems can be created due to high levels of Chloride present in the media. These problems can increase in areas were media has high water tables, poor drainage and low moisture. Chloride builds up in micro-irrigation system emitters and other water distribution channels that restrict adequate water flow. This decrease in water to plants restricts growth and increases irrigation system maintenance over time.

\section{$\underline{\text { Statistical Analysis }}$}

Method of analysis: Profile Analysis.

The method of statistical analysis was a profile analysis. The data analyzed used quality scores measured over time on 18 species grown in two media types. Only 17 of the 18 species of plants grown in $80 \%$ Sand/ $20 \%$ Peat Moss media could be analyzed because there were missing values (due to animal damage) for one species. There were 
18 species grown in 40\% Sand/ 40\% Peat Moss/ 20\% Perlite media. Quality scores were measured on each subject over the course of 12 weeks.

Profile analysis is a multivariate approach to investigating repeated measures with minimal assumptions about the correlation between the samples of data. The multivariate tests specify that there is no significant interaction effect between time (week) and media on quality score ( $\mathrm{p}$-value=.230), meaning that the difference in average quality score remains constant for each time period. The correlation between time (week) on quality score proved to have a significant interaction effect ( $\mathrm{p}$-value $=.000)$. This proved that average quality scores varied by week. Finally, media effect on aesthetic score (pvalue $=.014$ ) would indicate a significant correlation, showing that average quality score varied by media type.

\section{Conclusion and Recommendations}

The use of recycled water can be a very efficient and resourceful way to recapture a possible lost commodity. Plant species selection is the most important factor when considering the redistribution of recycled water. While many plants are capable of developing and growing normally, other plants are sensitive to recycled water irrigation. Since drip irrigation is the only option for irrigation with recycled water, the ideal management practice would include flushing the micro irrigation system with normal fresh irrigation water every 3-6 months. Direct contact of recycled water with leaves should be avoided at all times when irrigating with recycled water, with the exception of salt tolerant grasses. 
Soil characteristics play a large role in plant development with recycled irrigation water. Figure 36 shows that plants grown in 40\% Sand, 40\% Peat Moss, and $20 \%$ Perlite had larger quality scores than plants grown in $80 \%$ Sand and 20\% Peat Moss over the duration of the experiment. Proper soil management would include amending soils when excess sodium is present with gypsum and sulfur, and leaching soils with regular irrigation water. This helps to leach harmful salts such as chloride which disrupt irrigation systems and proper plant growth. Leaching the media with fresh water every 3 months is highly encouraged as a long-term soil management strategy. 


\section{Estimated Marginal Means of MEASURE_1}

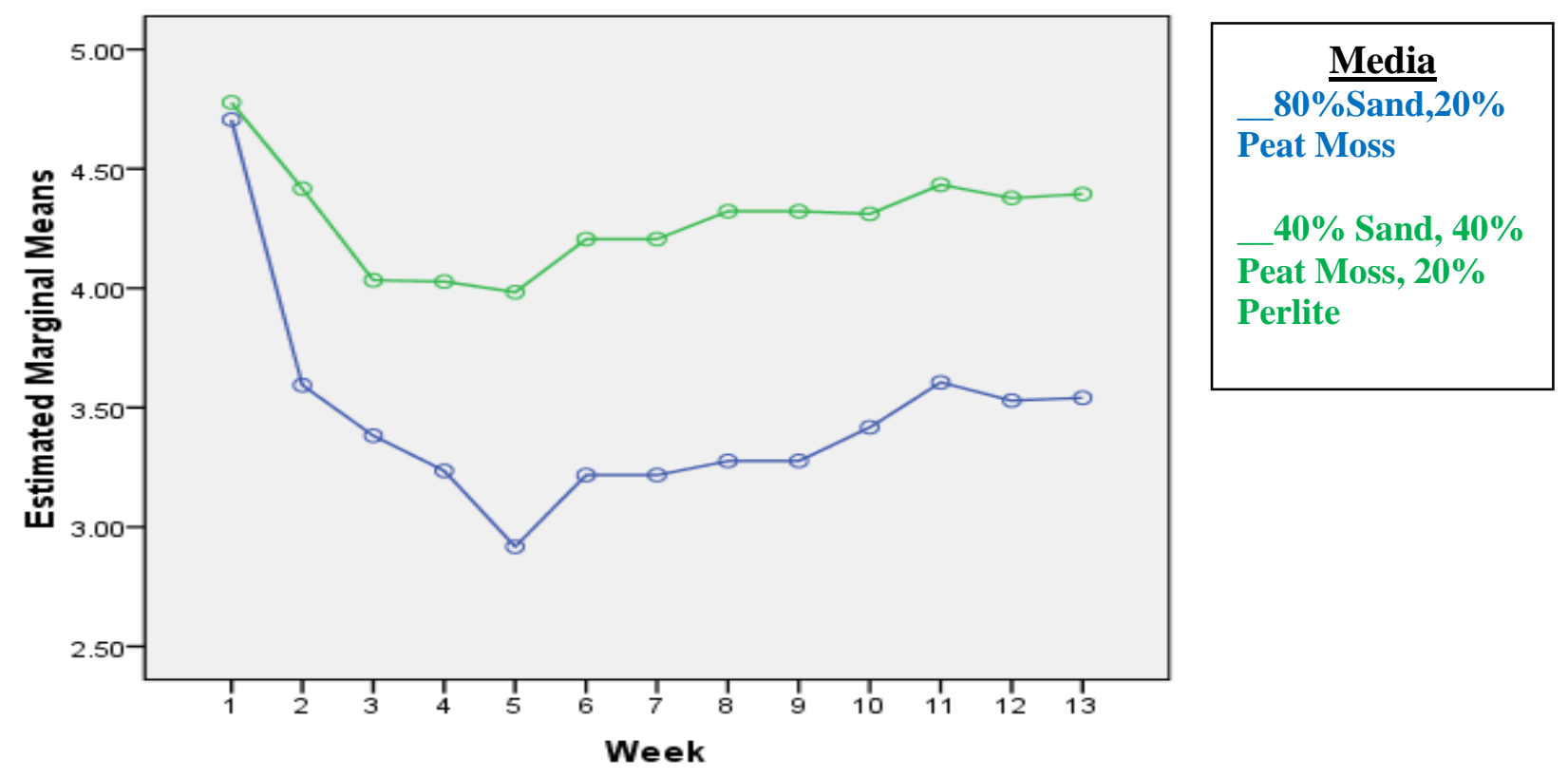

\section{Figure 36: Estimate Marginal Mean by Media}

The grasses and grass-like plants that were tolerant to recycled irrigation water from Paso Robles Wastewater Plant were Buchloe spp. and Yucca spp. The tolerant herbaceous perennials were Osteospermum fruticosum, Lavandula angustifolia,

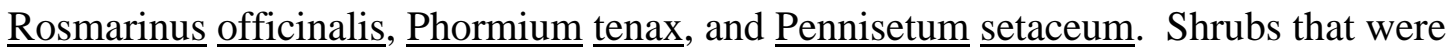
tolerant to recycled water irrigation were Cistus purpureus, Coprosma repens, Dodonea viscosa, Baccharis pilularis, Ceanothus thyrsiflorus, Thuja orientalis, Nerium oleander, and Eleagnus pungens. Tolerant annuals were Senecio cineraria, Antirrhinum majus, Primula spp., Viola spp., and Calendula officinalis. Of the groundcovers tested, Heuchera spp., Lonicera japonica, Vinca major, Hedera helix, and Ceanothus griseus were tolerant to recycled irrigation water. 


\section{$\underline{\text { References }}$}

Balks, .W. Bond J., C. Smith J. 1998. Effects of sodium accumulation on soil physical properties under an effluent-irrigated plantation. Aust. J. Soil Res. 36: 821-830

Bonds, Warren. J. 1998. Effluent irrigation- an environmental challenge for soil science. Aust. J. Soil Res. 36: 543-555

Brady, Nyle C. and Ray R. Weil. 2008. The nature and properties of soils. $14^{\text {th }}$ ed. Pearson Prentice Hall, Upper Saddle River, New Jersey.

Costello, Laurence R., E. Perry J., N. Matheny P, J. Michael Henry, P. Giesel M.. 2003. Abiotic disorders of landscape plants: a diagnostic guide. UCANR. Oakland, CA

Gross, A., O. Shmueli, Z. Ronen and E. Raveh. 2007. Recycled vertical flow constructed wetland (RVFCW)-a novel method of recycling greywater for landscape irrigation in small communities and households. Chemosphere. J. 66: 916-923

Halliwell, David J., K. Barlow M., D. Nash M. 2001. A review of the effects of wastewater sodium on soil properties and their implications for irrigation systems. Aust. J. Soil. Res. 39:1259-1267

Harivandi, A. 2004. Evaluating recycled water for golf course irrigation. USGA Green Section Record. Nov/Dec 42(6): pp.25-29

Harivandi, M.A.,Butler, J.D., and Wu, L. 1992. Salinity and turfgrass culture. Amer. Soc. of Agronomy. No. 32 pp. 207-229

Hussain, Ghulam and Adnan J.Al Saati. 1999. Wastewater quality and its reuse in agriculture Saudi Arabia, Desal. J. 123: 241-251

Kjelgren , Roger, L. Rupp, D. Kilgren. 2000. Water Conservation in Urban Landscapes. Hort.Sci. J.35 (6):1037-1040.

Kotuby-Amacher, Janice, R. Koenig, B. Kitchen. 2000. Salinity and plant tolerance. Electronic Publishing. https://extension.usu.edu/files/publications/publication/AGSO-03.pdf.

Lubello, Claudio, R. Gori, F. Nicese P., F. Ferrini. 2004. Municipal-treated wastewater reuse for plant nurseries irrigation. Water Res. 38(12): 2939-2947

Malkawi, Hanan I. and Munir J. Mohammad. 2003. Survival and accumulation of microorganisms in soils irrigated with secondary treated wastewater. J. Basic Microbiol. 43: 47-55 
Matheny, N.P., and J.R. Clark. 1998. Managing landscapes using recycled water. In D. Neely and G.W. Watson, eds., The landscape below ground II Champaign, IL: International Society of Arboriculture.

Miyamoto, S. 2006. Appraising salinity hazard to landscape plants and soils irrigated with moderately saline water. USDA under Agreement No. 4280001, El Paso Water Utilities and the Bureau of Reclamation.

Miyamoto, S. 2004. Landscape plant list for salt tolerance assessment. USDI Bureau of Reclamation. Texas Agricultural Experiment Station

Niu, Genhua and Denise S. Rodriguez. 2006 ${ }^{\mathrm{a}}$. Relative salt tolerance of selected herbaceous perennials and groundcovers. Science Direct. J. 110: (352-358)

Niu, Genhua and Denise S. Rodriguez. $2006^{\mathrm{b}}$. Relative salt tolerance of five herbaceous perennials. Hort. Sci. J. 41(6): pp. 1493-1497.

Pettygrove, G and T. Asano. 1985. Irrigation with reclaimed municipal wastewater-A guidance manual. Chelsea, MI: Lewis Publishers.

Quist, Tanya M. and Frank C. Williams. 1999. Irrigation water quality and ion balance in leaves of deciduous ornamental trees. J. of Plant Nut. 22 (6):1011-1019

Taiz, Lincoln and Eduardo Zeiger. 2006. Plant physiology. $4^{\text {th }}$ ed. Signauer Associates, Sunderland, MA

Toze, Simon. 2006. Reuse of effluent water-benefits and risks. Ag. Wat. Man. J. 80 (1-3): 147-159

USEPA. 2004. U.S. EPA, Offices of Water and Wastewater and compliance (Ed.) Guidelines for water reuse. U.S. EPA, Washington

USGS. United States Geological Survey. Water Science for Schools. http://ga.water.usgs.gov/edu

Wu, Lin, Guo X., Hunter, K., Zagory, E., Waters, R., Brown, J. 2000-2001. Studies of $\quad$ salt tolerance of landscape plant species and california native grasses for recycled water irrigation. Slosson report. http://slosson.ucdavis.edu/documents/2000- 20012053.pdf

Wu, Lu, Guo, X., Harivandi, A. 2001. Salt tolerance and salt accumulation of landscape plants irrigated by sprinkler and drip irrigation systems. J. Plant Nut. 24:1473- 1490 


\section{$\underline{\text { Appendix \#1 }}$}

Common Landscape Plants Listed by Salt Tolerance 


\section{Groundcovers}

\begin{tabular}{|c|c|c|}
\hline High & Moderate & Low \\
\hline Acacia redolens & Gazania splendens & Cotoneaster microphyllus \\
\hline Arctotheca calendula & Juniperus conferta & 'Rockspray' \\
\hline Atriplex lentiformis ssp. breweri & Juniperus horizontalis & Ophiopogon japonicus \\
\hline Atriplex spp. & Lantana montevidensis & Pachysandra terminalis \\
\hline Baccharis pilularis & Ophiopogon jaburan & Rosmarinus officinalis \\
\hline $\begin{array}{l}\text { Baccharis pilularis ssp. } \\
\text { consanguinia }\end{array}$ & $\begin{array}{l}\text { Rosmarinus officinalis } \\
\text { 'Prostratus' }\end{array}$ & $\begin{array}{l}\text { Trachelospermum jasminoides } \\
\text { Trifolium repens }\end{array}$ \\
\hline Ceanothus gloriosus & Trachelospermum & Vinca minor \\
\hline Delosperma alba & jasminoides & \\
\hline Drosanthemum hispidum & Trifolium fragiferum & \\
\hline \multicolumn{3}{|l|}{ Gazania aurantiacum } \\
\hline \multicolumn{3}{|l|}{ Gazania spp. } \\
\hline \multicolumn{3}{|l|}{ Ipomoea pes-caprae } \\
\hline \multicolumn{3}{|l|}{ Juniperus procumbens } \\
\hline \multicolumn{3}{|l|}{ Juniperus sabina 'Tamariscifolia' } \\
\hline \multicolumn{3}{|l|}{ Lampranthus productus } \\
\hline \multicolumn{3}{|l|}{ Lampranthus spectabilis } \\
\hline \multicolumn{3}{|l|}{ Lotus corniculatus } \\
\hline \multicolumn{3}{|l|}{ Malephora crocea } \\
\hline \multicolumn{3}{|l|}{ Mesembryanthemum spp. and var. } \\
\hline \multicolumn{3}{|l|}{ Myoporum parvifolium } \\
\hline \multicolumn{3}{|l|}{ Phyla nodiflora } \\
\hline \multicolumn{3}{|l|}{ Portulaca grandiflora } \\
\hline \multicolumn{3}{|l|}{ Rosmarinus officinalis } \\
\hline \multicolumn{3}{|l|}{ Rosmarinus officinalis } \\
\hline \multicolumn{3}{|l|}{ 'Lockwood de Forest' } \\
\hline Vinca major & & \\
\hline
\end{tabular}

\section{Herbaceous Plants}

\begin{tabular}{lll}
\hline Aloe vera & Achillea spp. & Alyssum saxatile \\
Asparagus densiflorus Sprengeri' & Agapanthus orientalis & Antirrhinum majus \\
Calocephalus brownii & Agapanthus umbellatus & Callistephus chinensis \\
Codiaeum punctatus & Ageratum spp. & Celosia argentea var. cristata \\
Dianthus caryophyllus & Artemesia stellerana & Cosmos bipinnatus \\
Helianthus debilis Nutt. & Asclepias tuberosa & Crassula ovata \\
Lathyrus japonicus & Asparagus densiflorus & Delphinium spp. \\
Lathyrus odoratus & Calendula officinalis & Dianthus barbatus \\
Oenothera speciosa childsii & Cereus peruvianus & Dianthus caryophyllus \\
Petunia hybrida & Chrysanthemum & Ensete ventricosum \\
Salvia spp. & morifolium 'Bronze Kramer' & Euphorbia pulcherrima \\
& Coreopsis grandiflora & 'Barbara Ecke' \\
& Crassula ovata & Euryops pectinatus \\
& Eschscholzia californica & Felicia amelloides
\end{tabular}


Herbaceous Plants, cont.

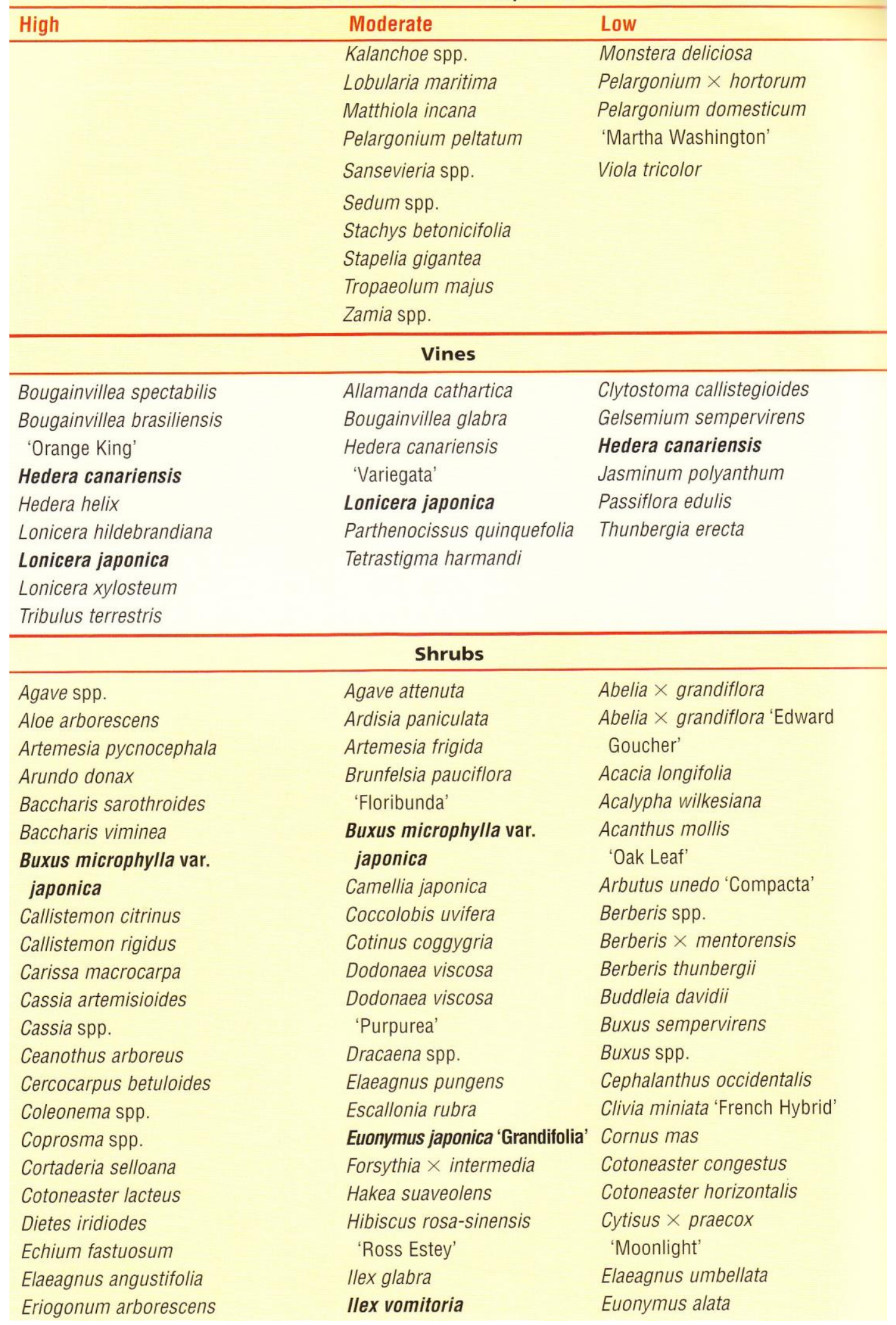


Shrubs, cont.

\begin{tabular}{|c|c|c|}
\hline High & Moderate & Low \\
\hline Eriogonum fasciculatum & Jacquinia armillaris & Euonymus japonica \\
\hline Eucalyptus lehmannii & Juniperus chinensis & 'Silver King' \\
\hline Euonymus japonica & Juniperus chinensis & Fatsia japonica \\
\hline Euonymus japonica 'Grandifolia' & 'Armstrong' & Feijoa sellowiana \\
\hline Euphorbia lactea & Juniperus chinensis & Forsythia $\times$ intermedia \\
\hline Fabiana imbricata & 'Kazuka' & 'Spring Glory' \\
\hline Fremontia mexicana & Juniperus chinensis & Gardenia augusta \\
\hline Furcraea gigantea & 'Pfitzerana' & Hibiscus rosa-sinensis \\
\hline Genista spp & Juniperus communis & Hibiscus rosa-sinensis \\
\hline Heteromeles arbutifolia & 'Hibernica' & 'Brillant' \\
\hline Hibiscus rosa-sinensis & Juniperus virginiana & Ilex $\times$ altaclarensis 'Wilsonii' \\
\hline 'President' & Lantana camara & Ilex cornuta \\
\hline Ilex cornuta & Leucophyllum frutescens & Ilex cornuta 'Burfordii' \\
\hline Ilex vomitoria & Ligustrum japonicum & Ilex cornuta 'Dazzler' \\
\hline Isomeris arborea & Ligustrum Iucidum & Ilex ораса \\
\hline Juniperus californica & Myrica pensylvanica & Juniperus scopulorum 'Moffetti' \\
\hline Juniperus chinensis & Myrtus communis & Lantana 'Confetti' \\
\hline 'Robusta Green’ & Nerium oleander & Leptospermum laevigatum \\
\hline Juniperus virginiana 'Skyrocket' & 'Cherry Ripe' & Mahonia aquifolium \\
\hline Lavatera assurgentiflora & Ochrosia elliptica & Mahonia aquifolium 'Compacta' \\
\hline Leptospermum laevigatum & Olea africana & Mahonia pinnata \\
\hline Leucophyllum frutescens & Philodendron selloum & Musa acuminata \\
\hline Ligustrum spp. & Phormium tenax & Nandina domestica \\
\hline Mahonia nevinii & Pittosporum tobira & Philodendron bipinnatifidum \\
\hline Myoporum laetum & Prunus caroliniana & Phormium tenax \\
\hline Myrtus communis & Pyracantha cernato-serrata & 'Atropurpureum' \\
\hline Myrtus communis 'Compacta' & Pyracantha cernato-serrata & Photinia $\times$ fraseri \\
\hline Nerium oleander & 'Graberi' & Photinia serrulata \\
\hline Olea europaea 'Montra' & Pyracantha coccinea & Pittosporum tobira \\
\hline Phormium tenax & Rhaphiolepis indica & Pittosporum tobira 'Variegata' \\
\hline Pittosporum crassifolium & 'Enchantress' & Podocarpus macrophyllus var. \\
\hline Pittosporum tobira & Rhaphiolepis umbellata & maki \\
\hline Plumbago auriculata & Rhaphiolepsis indica & Punica granatum \\
\hline Psidium cattleianum & Shepherdia argentea & Rhamnus alaternus \\
\hline Punica granatum 'Wonderful' & Strelitzia reginae & Rhododendron spp. \\
\hline Pyracantha cernato-serrata 'Graberi' & Syzygium paniculatum & Rhododendron spp. \\
\hline Pyracantha coccinea & Teucrium chamadrys & Ribes spp. \\
\hline Rhamnus californica & Thuja occidentalis & Rosa 'Grenoble' \\
\hline Rhaphiolepsis indica & Thuja orientalis & Rosa multiflora \\
\hline Rhus integrifolia & Viburnum tinus 'Robustum' & Rosa spp. \\
\hline Rhus ovata & Woodwardia spp. & Salix purpurea var. nana \\
\hline Rhus trilobata & Xylosma congestum & Sambucus nigra \\
\hline Rosa hybrida & Zanthoxylum fagara & Spiraea vanhouttei \\
\hline Rosa rugosa & & Strelitzia reginae \\
\hline Simmondsia chinensis & & Viburnum tinus \\
\hline Spartium junceum & & Yucca filamentosa \\
\hline
\end{tabular}


Shrubs, cont.

\begin{tabular}{lll}
\hline High & Moderate & Low \\
\hline Tamarix aphylla & & \\
Tamarix gallica & & \\
Tamarix parviflora & & \\
Thuja orientalis 'Aurea' & & \\
Yucca aloifolia & & \\
Yucca filamentosa & & \\
Yucca spp. & Grasses & Agrostis tenuis \\
\hline \hline & Bouteloua gracilis & Eremochloa ophiuroides \\
Cynodon dactylon & Dactylis glomerata & Festuca ovina var. glauca \\
Paspalum vaginatum & Festuca arundinacea & Festuca rubra \\
Succinellia spp. & Festuca rubra var. & Poa annua \\
Uniola paniculata & commutata & Poa pratensis \\
Zoysia tenuifolia & Lolium perenne & Poa trivialis \\
& &
\end{tabular}

(Costello et al. 2003 from Matheny and Clark 1998) 


\section{$\underline{\text { Appendix \#2 }}$}

\section{$\underline{\text { Additional Grasses and Shrubs Listed by Salt }}$ Tolerance}


Additional Grasses and Shrubs

\begin{tabular}{|c|c|c|c|}
\hline \multicolumn{2}{|c|}{ Warm Season } & \multicolumn{2}{|c|}{ Cool Season } \\
\hline \multicolumn{4}{|c|}{ Sensitive $\left(<3 \mathrm{dS} \mathrm{m}^{-1}\right)$} \\
\hline \multirow{3}{*}{ Black grama } & (Bouteloua eriopoda) & Kentucky bluegrass & (Poa pratensis) \\
\hline & & Rough bluegrass & (Poa trivialis) \\
\hline & & Colonial bentgrass & (Agrostis capillaris) \\
\hline \multicolumn{4}{|c|}{ Moderately Sensitive (3 - $\left.6 \mathrm{dS} \mathrm{m}^{-1}\right)$} \\
\hline Bahiagrass & (Paspalum notatum $)$ & Plains bluegrass & (Poa arida $)$ \\
\hline Blue grama & (Bouteloua gracilis 'Alma' ) & Big bluegrass & (Poa secunda) \\
\hline Buffalograss & (Buchloe dactyloides) & Creeping bentgrass & (Agrostis palustris) \\
\hline \multirow[t]{2}{*}{ Blue grama } & (Bouteloua gracilis 'Bad River') & Annual ryegrass & (Lolium multiforum) \\
\hline & & Intermediate wheatgrass & (Elytrigia intermedia 'Rush') \\
\hline \multicolumn{4}{|c|}{ Moderately Tolerant $\left(6-8 \mathrm{dS} \mathrm{m}^{-1}\right)$} \\
\hline \multirow{5}{*}{\multicolumn{2}{|c|}{ Zoysiagrass 'Zenith' (Zoysia sp. hybrid) }} & Intermediate wheatgrass & (Elytrigia intermedia 'Topar') \\
\hline & & Streambank wheatgrass & (Elymus lanceolatus) \\
\hline & & Crested wheatgrass & (Agropyron desertorum) \\
\hline & & Red fescue & (Festuca rubra) \\
\hline & & Perennial ryegrass & (Lolium perenne) \\
\hline \multicolumn{4}{|c|}{ Tolerant $\left(8-10 \mathrm{dS} \mathrm{m}^{-1}\right)$} \\
\hline Bermudagrass & (Cynodon dactylon ) & Tall fescue & (Festuca arundinacea) \\
\hline St. Augustinegrass & (Stenotaphrum secundatum) & Wild ryegrass 'Rio' & (Elymus triticoides) \\
\hline \multicolumn{4}{|c|}{ Highly Tolerant $\left(>10 \mathrm{dS} \mathrm{m}^{-1}\right)$} \\
\hline Alkali muhly & (Muhlenbergia asperifolia) & Tall wheatgrass & (Thinopyrum ponticum ) \\
\hline Desert saltgrass & (Distichlis spicata) & Fults alkaligrass & (Puccinellia distans) \\
\hline
\end{tabular}

\begin{tabular}{|c|c|c|c|}
\hline \multicolumn{2}{|c|}{$\begin{array}{l}\text { Vines \& Bedding Plants } \\
\end{array}$} & \multicolumn{2}{|c|}{ Ground Cover Plants } \\
\hline \multicolumn{2}{|c|}{ Sensitive $\left(<3 \mathrm{dS} \mathrm{m}^{-1}\right)$} & & \\
\hline Virginia creeper & (Parthenocissus quinquefolia) & Vinca & (Vinca major) \\
\hline English ivy & (Hedera helix) & Asian jasmine & (Trachelospermum asiaticum) \\
\hline Star jasmine & (Trachelospermum jasminoides) & Carolina jasmine & (Gelsemium sempervirens) \\
\hline Japanese honeysuckle & (Lonicera japonica) & Spring cinquefoil & (Potentilla tabernaemontanii) \\
\hline Lily of the Nile & (Agapanthus africanus) & Mexican primerose & (Oenothera berlandieri) \\
\hline Begonia & $(\text { Begonia sp. })^{*}$ & & \\
\hline Gerbera & (Gerbera jamesonti) & & \\
\hline \multicolumn{4}{|c|}{ Moderately Sensitive (3 - $\left.6 \mathrm{dS} \mathrm{m}^{-1}\right)$} \\
\hline Coleus & (Coleus hybridus)* & Trailing lantana & (Lantana montevidensis) \\
\hline Carnation & $(\text { Dianthus sp. })^{*}$ & Lantana & (L. camara) \\
\hline Aster & (Aster sp.) & Spreading acasia & (Acacia redolens) \\
\hline \multicolumn{4}{|c|}{ Moderately Tolerant $\left(6-8 \mathrm{dS} \mathrm{m}^{-1}\right)$} \\
\hline \multirow[t]{4}{*}{ Germanium } & $(\text { Pelargonium sp. })^{*}$ & Fountaingrass & (Pennisetum setaceum) \\
\hline & & Juniper & (Juniperus chinensis) \\
\hline & & Coyote brush & (Baccharis pilularis) \\
\hline & & Spider plant & (Chlorophytum comosum)* \\
\hline \multirow[t]{5}{*}{ Tolerant $\left(8-10 \mathrm{dS} \mathrm{m}^{-1}\right)$} & & & \\
\hline & & Bougainvillea & (Bougainvillea spectabillis)* \\
\hline & & Creeping boobialla & (Myoporum parvifolium) \\
\hline & & Ice plant & (Carpobrotus chilensis) \\
\hline & & Trailing Ice plant & (Lampranthus spectabilis) \\
\hline
\end{tabular}




\begin{tabular}{|c|c|}
\hline \multicolumn{2}{|c|}{ Shrubs } \\
\hline \multicolumn{2}{|l|}{ Sensitive $\left(<3 \mathrm{dS} \mathrm{m}^{-1}\right)$} \\
\hline Rose & (Rosasp.) \\
\hline Nandina & (Nandina domestica) \\
\hline Red tip photinia & (Photinia fraseri) \\
\hline Burford holly & (Ilex cornuta, 'Burfordii') \\
\hline Chinese holly & (Ilex cornuta) \\
\hline Pyrenees cotoneaster & (Cotoneaster congestus) \\
\hline Cotoneaster & (Cotoneaster buxifolius) \\
\hline Texas Mt. laurel & (Sophora secundiflora) \\
\hline \multicolumn{2}{|c|}{ Moderately Sensitive (3 - $\left.6 \mathrm{dS} \mathrm{m}^{-1}\right)$} \\
\hline Oriental arborvitae & (Thuja orientalis) \\
\hline Japanese boxwood & (Buxus microphylla) \\
\hline Glossy privet & (Ligustrum lucidum) \\
\hline Indian hawthorn & (Raphiolepis indica) \\
\hline Yaupon holly & (Ilex vomitoria) \\
\hline Dwarf pittosporum & (Pittosporum tobira) \\
\hline Blue point juniper & (Juniperus chinenses) \\
\hline Hollywood juniper & (Juniperus chinenses) \\
\hline Spreading juniper & (Juniperus chinenses) \\
\hline Pyracantha & (Pyracantha fortuneana) \\
\hline Silverberry & (Elaeagnus pungens) \\
\hline \multicolumn{2}{|c|}{ Moderately Tolerant (6 - $\left.8 \mathrm{dS} \mathrm{m}^{-1}\right)$} \\
\hline Rosemary & (Rosmarinus officinalis) \\
\hline Spreading acacia & (Acacia redolens) \\
\hline Bottle brush* & (Callistemon viminalis) \\
\hline Bougainvillea* & (Bougainvillea spectabilis) \\
\hline Coyotebush & (Baccharis pilularis) \\
\hline Japanese euonymus & (Euonymus japonica) \\
\hline Oleander & (Nerium oleander) \\
\hline Texas sage & (Leucophyllum frutescens) \\
\hline European olive & (Olea europaea $)$ \\
\hline \multicolumn{2}{|l|}{ Tolerant $\left(8-10 \mathrm{dS} \mathrm{m}^{-1}\right)$} \\
\hline \multicolumn{2}{|c|}{ Highly Tolerant (>10 dS m $\left.\mathrm{m}^{-1}\right)$} \\
\hline
\end{tabular}

(Miyamoto et al. 2004) 


\section{Appendix 3 \\ Materials Purchased: Phase 1 and 2}




\section{Phase 1}

\begin{tabular}{|l|l|}
\hline \multicolumn{1}{|c|}{ Irrigation Parts } & \multicolumn{1}{c|}{ Miscellaneous Parts } \\
\hline 180- Spaghetti Drip Tube Emitters & 135- Plastic Sandwich Baggies \\
\hline 200 ft- Black Plastic Drip Irrigation Tubing & $\begin{array}{l}\text { 2- Soil Mixtures (80\% Sand, 20\% Peat } \\
\text { Moss) (40\% Sand, 40\% Peat Moss, 20\% } \\
\text { Perlite) }\end{array}$ \\
\hline 1-Drip Tube Punch & 1- Soil Probe \\
\hline 16- Drip Tube Pinches & 180- 3 gal black containers \\
\hline 1- 3/4" Electrical Valve & 8- Cans of white spray paint \\
\hline $\begin{array}{l}\text { 2- 8 Outlet 3/4" constructed manifolds with } \\
\text { drip tube reducers }\end{array}$ & 1- Digital Camera \\
\hline 2- Cans of Irrigation glue & 1- Observation Notebook \\
\hline $\begin{array}{l}\text { 1- Rainbird 7 Valve Electrical Irrigation } \\
\text { Clock }\end{array}$ & 180- plant tags \\
\hline 40 ft. of class 200 pipe & \\
\hline
\end{tabular}

\section{Phase 2}

\begin{tabular}{|c|c|}
\hline Irrigation Parts & Miscellaneous Parts \\
\hline 216- spaghetti drip tube emitters & 200- black \#2 nursery containers \\
\hline 220 ft.- black drip tubing & 200- plant tags \\
\hline 1-drip tube punch & 1- soil probe \\
\hline $2-3 / 4 "$ to $1 / 2 "$ Reducing couplers & 50- plastic zip-lock bags \\
\hline $\begin{array}{l}10-1 / 2 " \times 1 / 2 " \times 1 / 2 " \text { T's w/ drip tube } \\
\text { connectors }\end{array}$ & 16- 2'x 2'x 1' Redwood Boxes \\
\hline
\end{tabular}




\section{Appendix 4 \\ Amount of Growing Substrate for Each Media: Phase \\ $\underline{1 \text { and } 2}$}


The volume of the number 2 nursery containers was determined as .00699 cubic yards.

The amount of growing substrate needed for each media is shown below:

\section{Phase 1}

80\% Sand $/ 20 \%$ Peat Moss Mixture

.6291 cubic yards of $80 \% / 20 \%$ mix

40\% Sand/ $40 \%$ Peat Moss / $20 \%$ Perlite Mixture

.6291 total cubic yards of $40 \% / 40 \% / 20 \% \mathrm{mix}$

Phase 2

40\% Sand/ $40 \%$ Peat Moss/ $20 \%$ Perlite Mixture

1.258 total cubic yards of $40 \% / 40 \% / 20 \% \mathrm{mix}$

16- 2' x 2'x 1' Redwood Boxes

$\left(1.5^{\prime} \times 1.5^{\prime} \times 1^{\prime}\right) / 27=.0833$ cubic yards of $\mathbf{4 0 \%} / 40 \% / 20 \%$ soil mixture per box

1.3333 cubic yards of total media 


\section{Appendix \#5 \\ Results of Water Analysis}


a.

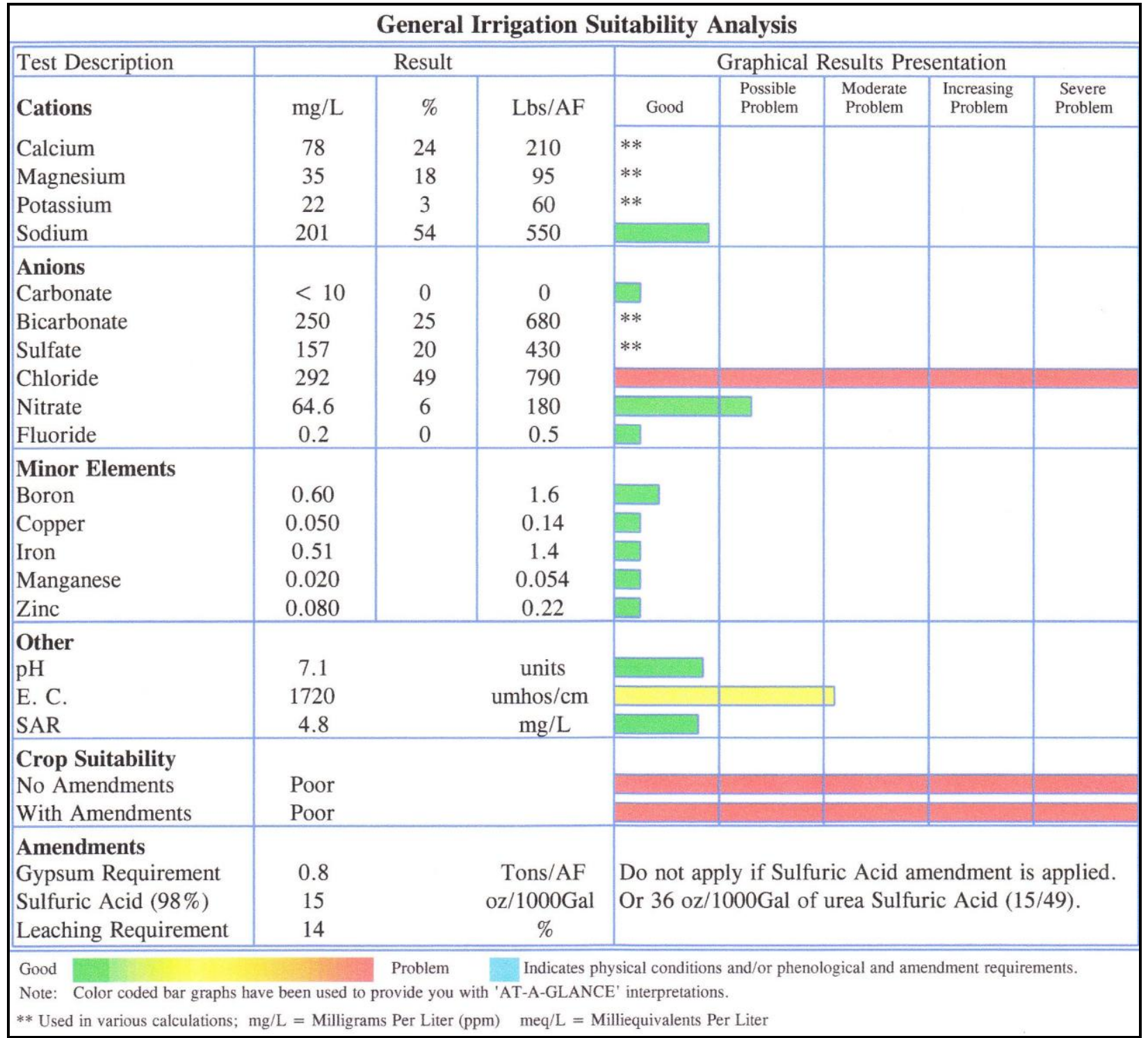

(Water analysis taken on installation week of phase I) 
b.

\begin{tabular}{|c|c|c|c|c|c|}
\hline \multicolumn{6}{|c|}{ Micro Irrigation System Plugging Hazard } \\
\hline Test Description & \multicolumn{2}{|c|}{ Result } & \multicolumn{3}{|c|}{ Graphical Results Presentation } \\
\hline \multirow{4}{*}{$\begin{array}{l}\text { Chemical } \\
\text { Manganese } \\
\text { Iron } \\
\text { TDS by Summation }\end{array}$} & \multirow{4}{*}{$\begin{array}{c}0.04 \\
2.6 \\
1100\end{array}$} & \multirow{4}{*}{$\begin{array}{l}\mathrm{mg} / \mathrm{L} \\
\mathrm{mg} / \mathrm{L} \\
\mathrm{mg} / \mathrm{L}\end{array}$} & Slight & \multirow{2}{*}{ Moderate } & \multirow[t]{2}{*}{ Severe } \\
\hline & & & \multirow{2}{*}{-0} & & \\
\hline & & & & & \\
\hline & & & & $\square$ & \\
\hline No Amendments & 71 & units & & & \\
\hline Alkalinity & 190 & $\mathrm{mg} / \mathrm{L}$ & & & \\
\hline Total Hardness & 337 & $\mathrm{mg} / \mathrm{L}$ & & & \\
\hline $\begin{array}{l}\text { With Amendments } \\
\text { Alkalinity }\end{array}$ & 38 & & & & \\
\hline Total Hardness & 38 & $\mathrm{mg} / \mathrm{L}$ & 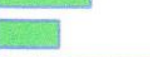 & & \\
\hline $\mathrm{pH}$ & $5.4-6.7$ & units & & & \\
\hline
\end{tabular}

(Water analysis taken on installation week of phase I) 
c.

\begin{tabular}{|c|c|c|c|c|c|c|c|c|}
\hline \multicolumn{9}{|c|}{ General Irrigation Suitability Analysis } \\
\hline Test Description & \multicolumn{3}{|c|}{ Result } & \multicolumn{5}{|c|}{ Graphical Results Presentation } \\
\hline Cations & $\mathrm{mg} / \mathrm{L}$ & $\%$ & $\mathrm{Lbs} / \mathrm{AF}$ & Good & $\begin{array}{l}\text { Possible } \\
\text { Problem }\end{array}$ & $\begin{array}{l}\text { Moderate } \\
\text { Problem }\end{array}$ & $\begin{array}{c}\text { Increasing } \\
\text { Problem }\end{array}$ & $\begin{array}{l}\text { Severe } \\
\text { Problem }\end{array}$ \\
\hline $\begin{array}{l}\text { Calcium } \\
\text { Magnesium } \\
\text { Potassium } \\
\text { Sodium } \\
\end{array}$ & $\begin{array}{c}79 \\
34 \\
20 \\
203 \\
\end{array}$ & $\begin{array}{c}25 \\
17 \\
3 \\
55\end{array}$ & $\begin{array}{c}210 \\
92 \\
54 \\
550\end{array}$ & $\begin{array}{l}* * \\
* * \\
* *\end{array}$ & & & & \\
\hline $\begin{array}{l}\text { Anions } \\
\text { Carbonate } \\
\text { Bicarbonate } \\
\text { Sulfate }\end{array}$ & $\begin{array}{l}<10 \\
230 \\
156\end{array}$ & $\begin{array}{c}0 \\
22 \\
19\end{array}$ & $\begin{array}{c}0 \\
630 \\
420\end{array}$ & $* *$ & & & & \\
\hline Chloride & 304 & 51 & 830 & & & & & \\
\hline Nitrate & 73.4 & 7 & 200 & & & & & \\
\hline Fluoride & 0.6 & 0 & 2 & 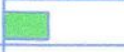 & & & & \\
\hline $\begin{array}{l}\text { Minor Elements } \\
\text { Boron } \\
\text { Copper } \\
\text { Iron } \\
\text { Manganese } \\
\text { Zinc }\end{array}$ & $\begin{array}{c}0.50 \\
0.070 \\
2.6 \\
0.040 \\
0.89\end{array}$ & & $\begin{array}{c}1.4 \\
0.19 \\
7.1 \\
0.11 \\
2.4\end{array}$ & 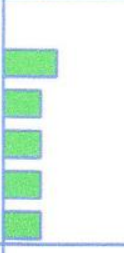 & & & & \\
\hline $\begin{array}{l}\text { Other } \\
\mathrm{pH} \\
\text { E. C. } \\
\text { SAR }\end{array}$ & $\begin{array}{c}7.1 \\
1760 \\
4.8 \\
\end{array}$ & & $\begin{array}{c}\text { units } \\
\text { umhos/cm } \\
\mathrm{mg} / \mathrm{L}\end{array}$ & & & $\square$ & & \\
\hline Crop Suitability & & & & & & & & \\
\hline No Amendments & Poor & & & & & & & \\
\hline With Amendments & Poor & & & & & & & \\
\hline $\begin{array}{l}\text { Amendments } \\
\text { Gypsum Requirement } \\
\text { Sulfuric Acid (98\%) } \\
\text { Leaching Requirement }\end{array}$ & $\begin{array}{l}0.7 \\
13 \\
14\end{array}$ & & $\begin{array}{c}\text { Tons/AF } \\
\text { oz/1000Gal } \\
\%\end{array}$ & \multicolumn{5}{|c|}{$\begin{array}{l}\text { Do not apply if Sulfuric Acid amendment is applied. } \\
\text { Or } 32 \mathrm{oz} / 1000 \mathrm{Gal} \text { of urea Sulfuric Acid (15/49). }\end{array}$} \\
\hline $\begin{array}{l}\text { Good } \\
\text { Note: Color coded bar graphs } \\
\text { ** Used in various calculations; }\end{array}$ & $\begin{array}{l}\text { been used } \\
\mathrm{L}=\text { Millig }\end{array}$ & $\begin{array}{l}\text { Problem } \\
\text { vide you } \\
\text { Per Liter }\end{array}$ & $\begin{array}{r}\text { Indicates pl } \\
\text { AT-A-GLANC } \\
\text { n) } \quad \text { meq } / \mathrm{L}=\mathrm{N}\end{array}$ & $\begin{array}{l}\text { sical conditi } \\
\text { lliequivalents }\end{array}$ & $\begin{array}{l}\text { and/or phen } \\
\text { Liter }\end{array}$ & gical and am & dment require & ents. \\
\hline
\end{tabular}

\section{(*Water analysis taken on week 11 of phase 1)}


d.

\begin{tabular}{|c|c|c|c|c|c|}
\hline \multicolumn{6}{|c|}{ Micro Irrigation System Plugging Hazard } \\
\hline Test Description & \multicolumn{2}{|c|}{ Result } & \multicolumn{3}{|c|}{ Graphical Results Presentation } \\
\hline \multirow{4}{*}{$\begin{array}{l}\text { Chemical } \\
\text { Manganese } \\
\text { Iron } \\
\text { TDS by Summation }\end{array}$} & \multirow{4}{*}{$\begin{array}{c}0.02 \\
0.51 \\
1100\end{array}$} & \multirow{4}{*}{$\begin{array}{l}\mathrm{mg} / \mathrm{L} \\
\mathrm{mg} / \mathrm{L} \\
\mathrm{mg} / \mathrm{L}\end{array}$} & Slight & Moderate & Severe \\
\hline & & & \multirow[t]{3}{*}{$\square$} & & \\
\hline & & & & $\square$ & \\
\hline & & & & $\square$ & \\
\hline \multirow{3}{*}{$\begin{array}{l}\text { No Amendments } \\
\text { pH } \\
\text { Alkalinity } \\
\text { Total Hardness }\end{array}$} & 71 & \multirow{3}{*}{$\begin{array}{l}\text { units } \\
\mathrm{mg} / \mathrm{L} \\
\mathrm{mg} / \mathrm{L}\end{array}$} & & & \\
\hline & 210 & & & & \\
\hline & 339 & & & $\square$ & \\
\hline \multirow{3}{*}{$\begin{array}{l}\text { With Amendments } \\
\text { Alkalinity } \\
\text { Total Hardness } \\
\text { pH }\end{array}$} & & \multirow{3}{*}{$\begin{array}{l}\mathrm{mg} / \mathrm{L} \\
\text { units }\end{array}$} & & & \\
\hline & 42 & & $\square$ & & \\
\hline & $5.4-6.7$ & & & & \\
\hline
\end{tabular}

(*Water analysis taken on week 11 of phase 1) 


\section{Appendix 6 \\ Weekly Plant Quality Scores}


cultorum- 1

B. x semperflorens-

cultorum-2

Gazania spp.- 1

Gazania spp.- 2

5.0

5.0

3.5

5.0

3.8

4.5

3.0

3.5

2.8

3.0

3.0

4.0

2.5

1.5

1.0

3.5

2.5

1.5

\begin{tabular}{|c|c|c|c|c|c|c|}
\hline Grasses & $\begin{array}{c}\text { Week } 6 \\
(9 / 29 / 08)\end{array}$ & $\begin{array}{c}\text { Week } 7 \\
(10 / 6 / 08)\end{array}$ & $\begin{array}{c}\text { Week } 8 \\
(10 / 13 / 08)\end{array}$ & $\begin{array}{c}\text { Week } 9 \\
(10 / 20 / 08)\end{array}$ & $\begin{array}{c}\text { Week 10 } \\
(10 / 27 / 08)\end{array}$ & $\begin{array}{l}\text { Week 11 } \\
(11 / 3 / 08)\end{array}$ \\
\hline C. dactylon- 1 & 4.0 & 3.5 & 3.8 & 4.3 & 4.0 & 4.3 \\
\hline C. dactylon- 2 & 4.0 & 4.0 & 3.5 & 4.3 & 4.0 & 4.3 \\
\hline P. vaginatum- 1 & 4.5 & 4.3 & 4.8 & 4.0 & 4.3 & 4.3 \\
\hline P. vaginatum- 2 & 5.0 & 5.0 & 5.0 & 4.3 & 4.8 & 4.8 \\
\hline Yucca spp.- 1 & 3.5 & 3.5 & 3.5 & 3.8 & 3.8 & 4.0 \\
\hline Yucca spp- 2 & 3.8 & 4.3 & 4.3 & 4.0 & 4.3 & 4.3 \\
\hline Buchloe spp- 1 & 4.8 & 4.8 & 5.0 & 5.0 & 4.8 & 5.0 \\
\hline Buchloe- 2 & 5.0 & 5.0 & 5.0 & 5.0 & 5.0 & 5.0 \\
\hline \multicolumn{7}{|l|}{ Herbaceous Perennials } \\
\hline O. fruticosum- 1 & 4.5 & 5.0 & 5.0 & 4.8 & 5.0 & 5.0 \\
\hline O. fruticosum- 2 & 4.5 & 5.0 & 5.0 & 5.0 & 5.0 & 5.0 \\
\hline L. camara- 1 & 4.3 & 4.8 & 5.0 & 5.0 & 4.8 & 4.8 \\
\hline L. camara- 2 & 5.0 & 5.0 & 5.0 & 5.0 & 5.0 & 5.0 \\
\hline T. lemmonii- 1 & 3.2 & 3.0 & 4.0 & 3.8 & 4.3 & 4.5 \\
\hline T. lemmonii-2 & 3.5 & 3.8 & 4.0 & 4.3 & 4.8 & 5.0 \\
\hline F. chiloensis-1 & 0.0 & 0.0 & 0.0 & 0.0 & 0.0 & 0.0 \\
\hline F. chiloensis- 2 & 5.0 & 5.0 & 5.0 & 5.0 & 5.0 & 5.0 \\
\hline L. angustifolia- 1 & 4.0 & 4.5 & 4.8 & 4.8 & 4.8 & 4.8 \\
\hline L. angustifolia- 2 & 4.3 & 4.8 & 5.0 & 5.0 & 5.0 & 5.0 \\
\hline \multicolumn{7}{|l|}{ Shrubs } \\
\hline M. californica- 1 & 2.5 & 3.0 & 3.0 & 2.5 & 3.8 & 3.3 \\
\hline M. californica- 2 & 4.5 & 5.0 & 5.0 & 4.8 & 4.5 & 4.3 \\
\hline C. purpureus- 1 & 3.5 & 3.5 & 4.5 & 4.0 & 4.3 & 4.5 \\
\hline C. purpureus- 2 & 4.0 & 4.3 & 4.8 & 4.5 & 5.0 & 4.8 \\
\hline T. jasminoides- 1 & 3.5 & 3.5 & 4.3 & 4.3 & 4.3 & 3.0 \\
\hline T. jasminoides- 2 & 3.8 & 3.8 & 4.5 & 4.5 & 4.5 & 3.5 \\
\hline C. repens- 1 & 2.5 & 2.8 & 3.3 & 3.0 & 2.8 & 2.5 \\
\hline C. repens- 2 & 4.5 & 4.5 & 4.5 & 4.8 & 4.8 & 4.5 \\
\hline \multicolumn{7}{|l|}{ D. viscosa- 1} \\
\hline D. viscosa- 1 & 4.8 & 4.8 & 5.0 & 4.8 & 4.8 & 4.8 \\
\hline \multicolumn{7}{|l|}{ Annuals } \\
\hline S. cineraria- 1 & 2.8 & 2.5 & 2.5 & 3.0 & 3.5 & 3.5 \\
\hline S. cineraria- 2 & 5.0 & 4.5 & 4.8 & 4.8 & 4.8 & 4.5 \\
\hline Pelargonium spp.- 1 & 4.5 & 4.5 & 4.8 & 4.8 & 4.8 & 4.5 \\
\hline Pelargonium spp.- 2 & 5.0 & 5.0 & 5.0 & 5.0 & 5.0 & 5.0 \\
\hline B. $x$ semperflorens-cultorum- 1 & 1.5 & 2.0 & 1.5 & 1.0 & 1.0 & 1.0 \\
\hline B. x semperflorens-cultorum-2 & 3.0 & 2.5 & 2.5 & 2.5 & 2.5 & 3.0 \\
\hline G. spp.- 1 & 1.5 & 1.0 & 1.0 & 0.0 & 1.0 & 1.0 \\
\hline G. spp.- 2 & 2.0 & 1.5 & 1.5 & 0.0 & 1.0 & 1.0 \\
\hline
\end{tabular}




\begin{tabular}{|c|c|c|c|c|c|c|}
\hline Grasses & $\begin{array}{c}\text { Week 12 } \\
(11 / 10 / 08)\end{array}$ & $\begin{array}{c}\text { Week 16 } \\
(12 / 08 / 09)\end{array}$ & $\begin{array}{c}\text { Week 20 } \\
(01 / 05 / 09)\end{array}$ & $\begin{array}{c}\text { Week } \\
24 \\
(2 / 2 / 09)\end{array}$ & $\begin{array}{c}\text { Week 28 } \\
(03 / 05 / 09)\end{array}$ & $\begin{array}{c}\text { Week 32 } \\
(04 / 06 / 09)\end{array}$ \\
\hline C. dactylon- 1 & 4.3 & 3.0 & 1.0 & 1.0 & 1.0 & 3.0 \\
\hline C. dactylon- 2 & 4.5 & 4.0 & 1.5 & 2.5 & 2.8 & 4.0 \\
\hline P. vaginatum- 1 & 4.5 & 4.5 & 1.0 & 1.0 & 1.0 & 3.0 \\
\hline P. vaginatum- 2 & 4.8 & 4.8 & 2.0 & 2.5 & 2.5 & 4.0 \\
\hline Yucca spp.- 1 & 4.0 & 4.3 & 4.0 & 4.0 & 4.0 & 4.5 \\
\hline Yucca spp- 2 & 4.3 & 4.5 & 4.3 & 4.5 & 4.5 & 4.5 \\
\hline Buchloe spp- 1 & 5.0 & 4.8 & 3.5 & 4.0 & 4.0 & 4.0 \\
\hline Buchloe- 2 & 5.0 & 5.0 & 4.0 & 4.0 & 4.0 & 4.0 \\
\hline \multicolumn{7}{|l|}{ Herbaceous Perennials } \\
\hline O. fruticosum- 1 & 5.0 & 4.8 & 4.0 & 4.0 & 4.5 & 4.5 \\
\hline O. fruticosum- 2 & 5.0 & 5.0 & 3.5 & 4.5 & 4.5 & 4.5 \\
\hline L. camara- 1 & 4.8 & 4.8 & 1.0 & 0.0 & 0.0 & 0.0 \\
\hline L. camara- 2 & 5.0 & 4.8 & 1.0 & 0.0 & 0.0 & 0.0 \\
\hline T. lemmonii- 1 & 5.0 & 5.0 & 3.5 & 2.5 & 2.0 & 3.5 \\
\hline T. lemmonii-2 & 5.0 & 5.0 & 3.0 & 2.5 & 2.0 & 3.5 \\
\hline F. chiloensis-1 & 0.0 & 0.0 & 0.0 & 0.0 & 0.0 & 0.0 \\
\hline F. chiloensis- 2 & 5.0 & 5.0 & 4.5 & 4.0 & 3.5 & 3.5 \\
\hline L. angustifolia- 1 & 4.8 & 4.8 & 4.5 & 5.0 & 4.5 & 5.0 \\
\hline L. angustifolia- 2 & 5.0 & 5.0 & 4.8 & 5.0 & 4.5 & 5.0 \\
\hline \multicolumn{7}{|l|}{ Shrubs } \\
\hline M. californica- 1 & 3.3 & 3.0 & 3.5 & 4.0 & 3.8 & 4.0 \\
\hline M. californica- 2 & 4.0 & 3.0 & 4.0 & 4.0 & 4.0 & 3.5 \\
\hline C. purpureus- 1 & 4.5 & 4.3 & 4.5 & 4.5 & 4.8 & 5.0 \\
\hline C. purpureus- 2 & 4.8 & 4.5 & 4.8 & 4.8 & 4.8 & 5.0 \\
\hline T. jasminoides- 1 & 3.0 & 2.5 & 2.0 & 2.0 & 2.0 & 3.0 \\
\hline T. jasminoides- 2 & 3.3 & 3.0 & 2.5 & 2.0 & 2.0 & 3.0 \\
\hline C. repens- 1 & 2.5 & 2.5 & 2.0 & 2.0 & 2.0 & 0.0 \\
\hline C. repens- 2 & 4.8 & 5.0 & 4.5 & 4.0 & 4.0 & 4.5 \\
\hline \multicolumn{7}{|l|}{ D. viscosa- 1} \\
\hline D. viscosa- 1 & 4.8 & 4.8 & 5.0 & 5.0 & 5.0 & 5.0 \\
\hline \multicolumn{7}{|l|}{ Annuals } \\
\hline S. cineraria- 1 & 4.0 & 4.5 & 4.3 & 4.5 & 4.5 & 5.0 \\
\hline S. cineraria- 2 & 5.0 & 5.0 & 5.0 & 5.0 & 5.0 & 5.0 \\
\hline Pelargonium spp.- 1 & 4.5 & 4.5 & 3.8 & 3.5 & 3.0 & 3.5 \\
\hline Pelargonium spp.- 2 & 4.8 & 5.0 & 4.0 & 4.0 & 3.5 & 3.5 \\
\hline B. $x$ semperflorens-cultorum- 1 & 0.0 & 0.0 & 0.0 & 0.0 & 0.0 & 0.0 \\
\hline B. $x$ semperflorens-cultorum-2 & 3.0 & 3.0 & 0.0 & 0.0 & 0.0 & 0.0 \\
\hline Gazania spp.- 1 & 1.0 & 0.0 & 0.0 & 0.0 & 0.0 & 0.0 \\
\hline Gazania spp.- 2 & 1.0 & 0.0 & 0.0 & 0.0 & 0.0 & 0.0 \\
\hline
\end{tabular}




\begin{tabular}{|c|c|c|c|c|c|c|}
\hline & $\begin{array}{c}\text { Installation } \\
\text { Week } \\
(01 / 12 / 09) \\
\end{array}$ & $\begin{array}{c}\text { Week 1 } \\
(01 / 19 / 09)\end{array}$ & $\begin{array}{c}\text { Week 2 } \\
(01 / 26 / 09)\end{array}$ & $\begin{array}{c}\text { Week 3 } \\
(02 / 02 / 09)\end{array}$ & $\begin{array}{c}\text { Week } 4 \\
(02 / 09 / 09)\end{array}$ & $\begin{array}{c}\text { Week } 5 \\
(02 / 18 / 09)\end{array}$ \\
\hline \multicolumn{7}{|c|}{ Herbaceous Perennials } \\
\hline A. africanus & 5.0 & 4.5 & 4.5 & 4.5 & 4.0 & 4.0 \\
\hline R. officinalis & 5.0 & 5.0 & 5.0 & 5.0 & 5.0 & 5.0 \\
\hline P. tenax & 5.0 & 5.0 & 4.5 & 4.5 & 4.5 & 4.5 \\
\hline P. setaceum & 4.0 & 4.0 & 4.5 & 4.0 & 4.0 & 4.5 \\
\hline \multicolumn{7}{|l|}{ Shrubs } \\
\hline N. domestica & 4.5 & 4.0 & 4.0 & 4.0 & 4.0 & 4.0 \\
\hline P. $x$ fraseri & 3.5 & 3.0 & 3.5 & 3.5 & 3.5 & 3.5 \\
\hline I. cornuta & 5.0 & 4.5 & 4.0 & 4.0 & 4.0 & 3.5 \\
\hline E. pungens & 5.0 & 5.0 & 5.0 & 5.0 & 5.0 & 4.5 \\
\hline B. polularis & 5.0 & 5.0 & 5.0 & 5.0 & 5.0 & 5.0 \\
\hline C. thyrsiflorus & 4.0 & 5.0 & 4.0 & 4.5 & 4.5 & 4.5 \\
\hline T. orientalis & 4.5 & 4.5 & 4.0 & 4.5 & 4.5 & 4.0 \\
\hline N. oleander & 5.0 & 5.0 & 5.0 & 5.0 & 5.0 & 5.0 \\
\hline \multicolumn{7}{|l|}{ Groundcovers } \\
\hline Heuchera spp. & 4.0 & 4.0 & 3.5 & 3.5 & 4.0 & 4.0 \\
\hline L. japonica & 3.0 & 3.5 & 3.5 & 3.5 & 4.0 & 4.0 \\
\hline V. major & 4.5 & 4.5 & 4.5 & 4.5 & 4.5 & 4.5 \\
\hline H. helix & 5.0 & 5.0 & 4.5 & 4.5 & 5.0 & 5.0 \\
\hline Gazania spp. & 5.0 & 2.0 & 1.0 & 1.0 & 1.0 & 1.0 \\
\hline C. griseus & 4.0 & 4.5 & 4.0 & 4.0 & 4.0 & 4.5 \\
\hline \multicolumn{7}{|l|}{ Annuals } \\
\hline A. majus & 4.0 & 4.5 & 4.0 & 4.0 & 4.0 & 4.0 \\
\hline Calendula spp. & 5.0 & 5.0 & 4.0 & 4.0 & 4.5 & 4.5 \\
\hline Viola spp. & 5.0 & 5.0 & 4.5 & 4.0 & 4.0 & 4.0 \\
\hline Primula spp. & 5.0 & 4.5 & 4.0 & 3.0 & 4.0 & 4.0 \\
\hline
\end{tabular}




\begin{tabular}{|c|c|c|c|c|c|c|c|}
\hline & $\begin{array}{c}\text { Week 6 } \\
(02 / 25 / 09)\end{array}$ & $\begin{array}{c}\text { Week } 7 \\
(03 / 02 / 09)\end{array}$ & $\begin{array}{c}\text { Week } 8 \\
(03 / 09 / 09)\end{array}$ & $\begin{array}{c}\text { Week } 9 \\
(03 / 16 / 09)\end{array}$ & $\begin{array}{c}\text { Week 10 } \\
(03 / 23 / 09)\end{array}$ & $\begin{array}{c}\text { Week 11 } \\
(03 / 30 / 09)\end{array}$ & $\begin{array}{c}\text { Week 12 } \\
(04 / 06 / 09)\end{array}$ \\
\hline \multicolumn{8}{|l|}{$\begin{array}{l}\text { Herbaceous } \\
\text { Perennials }\end{array}$} \\
\hline A. africanus & 4.0 & 4.0 & 4.0 & 3.5 & 3.5 & 3.5 & 3.8 \\
\hline R. officinalis & 5.0 & 4.5 & 4.5 & 4.5 & 4.5 & 5.0 & 5.0 \\
\hline P. tenax & 4.5 & 4.5 & 4.0 & 4.0 & 4.0 & 4.0 & 4.8 \\
\hline P. setaceum & 4.0 & 4.0 & 4.0 & 4.0 & 4.0 & 4.0 & 4.3 \\
\hline \multicolumn{8}{|l|}{ Shrubs } \\
\hline N. domestica & 3.5 & 3.5 & 3.5 & 3.5 & 3.0 & 3.0 & 3.0 \\
\hline P. $x$ fraseri & 3.5 & 3.5 & 3.5 & 3.5 & 3.5 & 4.0 & 3.5 \\
\hline I. cornuta & 3.5 & 3.5 & 3.5 & 3.0 & 3.0 & 3.0 & 3.5 \\
\hline E. pungens & 4.5 & 4.5 & 4.5 & 4.5 & 4.5 & 4.5 & 4.8 \\
\hline B. polularis & 5.0 & 5.0 & 5.0 & 5.0 & 5.0 & 5.0 & 5.0 \\
\hline C. thyrsiflorus & 4.5 & 4.0 & 4.5 & 4.5 & 4.5 & 4.5 & 5.0 \\
\hline T. orientalis & 4.0 & 4.0 & 4.0 & 4.0 & 4.0 & 4.0 & 4.0 \\
\hline N. oleander & 5.0 & 5.0 & 5.0 & 5.0 & 5.0 & 5.0 & 5.0 \\
\hline \multicolumn{8}{|l|}{ Groundcovers } \\
\hline Heuchera spp. & 4.0 & 4.0 & 4.5 & 4.5 & 5.0 & 5.0 & 5.0 \\
\hline L. japonica & 4.0 & 4.5 & 4.5 & 4.5 & 4.5 & 4.5 & 4.8 \\
\hline V. major & 4.5 & 4.5 & 4.5 & 4.5 & 4.5 & 5.0 & 4.8 \\
\hline H. helix & 4.5 & 5.0 & 4.5 & 4.0 & 4.0 & 4.0 & 4.0 \\
\hline Gazania spp. & 1.0 & 1.0 & 1.0 & 1.0 & 1.0 & 3.0 & 2.0 \\
\hline C. griseus & 4.5 & 4.0 & 4.0 & 4.5 & 5.0 & 5.0 & 4.5 \\
\hline \multicolumn{8}{|l|}{ Annuals } \\
\hline A. majus & 4.0 & 4.0 & 4.5 & 4.5 & 4.5 & 5.0 & 5.0 \\
\hline Calendula spp. & 5.0 & 5.0 & 5.0 & 5.0 & 5.0 & 5.0 & 5.0 \\
\hline Viola spp. & 4.5 & 5.0 & 5.0 & 5.0 & 5.0 & 5.0 & 5.0 \\
\hline Primula spp. & 4.0 & 4.5 & 4.5 & 4.5 & 4.5 & 4.5 & 4.0 \\
\hline
\end{tabular}

